


\section{DIMENSIONES SOCIALES Y ECONÓMICAS DEL USO DEL RECURSO HÍDRICO}

Francisca Silva Hernández

Germán Martínez Prats Candelaria Guzmán Fernández Fabiola de Jesús Mapén Franco 
(POLI

(C) Institución Universitaria Politécnico

Grancolombiano

Dimensiones sociales y económicas del uso del recurso hídrico

Digital ISBN: 978-958-5142-70-1

Editorial Politécnico Grancolombiano

Calle 61 No. 7 - 66

Tel: 7455555, Ext. 1516

Bogotá, Colombia

\section{Autores:}

Francisca Silva Hernández

Germán Martínez Prats

Candelaria Guzmán Fernández

Fabiola de Jesús Mapén Franco

\section{Director Editorial:}

Eduardo Norman Acevedo

Analista de producción editorial:

Carlos Eduardo Daza Orozco

\section{Comité Editorial:}

Rafael Rentería Ramos, Universidad Nacional Abierta y A Distancia

Olga Lucía Ostos Ortiz

Universidad Santo Tomás

Claudio Camilo Gonzales Clavijo

Universidad Nacional Abierta y A Distancia

\section{Corrección de estilo:}

Leonardo Montenegro

Diseño y composición:

Christian Javier Niño Posada

\section{¿Cómo citar este libro?}

Silva, F. et. al. (2021). Dimensiones sociales y económicas del uso del recurso hídrico.

Bogotá, D. C., Colombia: Editorial

Politécnico Grancolombiano.

No se permite la reproducción total o parcial de esta obra, ni su incorporación a un sistema informático, ni su tratamiento en cualquier forma o medio existentes o por existir, sin el permiso previo y por escrito de los autores.

Para usos académicos y científicos, la Institución Universitaria Politécnico Grancolombiano accede al licenciamiento Creative Commons del contenido de la obra con: Atribución - No comercial - Sin derivar - Compartir igual.

Las opiniones expresadas son responsabilidad exclusiva del autor(es) y no constituye una postura institucional al respecto.

La Editorial del Politécnico Grancolombiano pertenece a la Asociación de Editoriales Universitarias de Colombia (ASEUC).

Creado en Colombia

Todos los derechos reservados 


\section{Contenido}

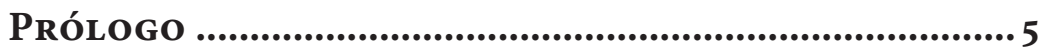

INTRODUCCIÓN ...................................................................... 7

I. DeRecho humano Al MEdio Ambiente ................ 11

Derecho a un medio ambiente sano y

ecológicamente equilibrado ......................................................... 13

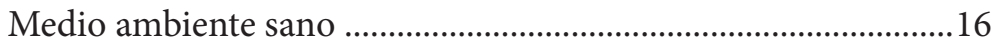

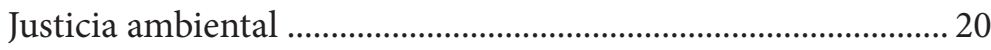

Derecho al agua ....................................................................... 23

Normas de origen externo ........................................................... 24

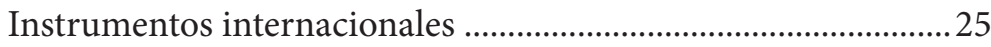

Instrumentos internacionales regionales interamericanos ....... 30

Instrumentos internacionales del derecho al agua de

los grupos vulnerables ............................................................... 32

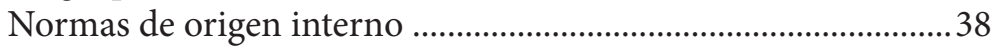

Obligaciones de los estados de garantizar el derecho al agua ... 40

Buenas prácticas de acceso al agua y saneamiento ..................... 43

iI. Agua. Enfoque Sistemático .............................47

Recurso hídrico. Perspectiva transversal ...................................... 49

El agua en sus diversas categorías ............................................... 52

Recurso natural .......................................................................... 53

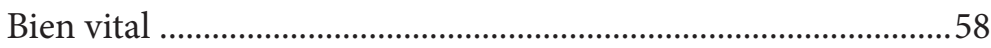

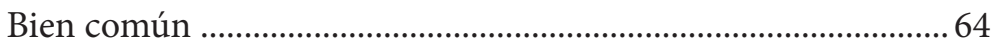

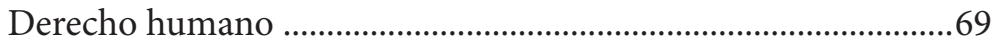

Seguridad mundial y nacional ...................................................... 75

Enfoque sociohidrológico .......................................................... 83

III. Aproximación ECONÓmica .................................8 89

Economía verde .......................................................................91

El agua en el sistema económico neoliberal ............................... 94

BibliografíA ................................................... 101 


\section{LISTA DE TABLAS}

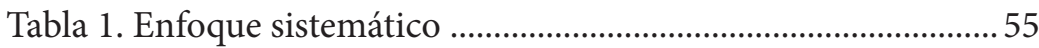

Tabla 2. Marco organizativo de la sociohidrología .............................85

Tabla 3. Definición de diversos conceptos verdes ............................. 92

\section{Lista de Gráficos}

Gráfico 1. Trinomio: individuo-medio ambiente 16

Gráfico 2. Obligaciones del Estado en la garantía del derecho al

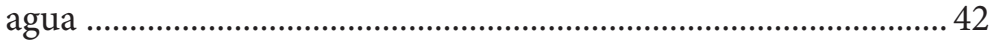

Gráfico 3. Buenas prácticas: agua y saneamiento ................................4 46

Gráfico 4. Planeación y gestión de los recursos hídricos ................. 83

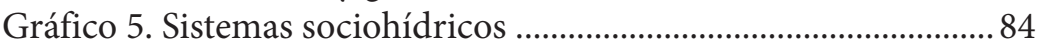




\section{Prólogo}

Carantizar la disponibilidad y la gestión sostenible del agua y Jel saneamiento para todos en América Latina y el Caribe es el sexto de los diecisiete "Objetivos del Desarrollo Sostenible (ODS) de la Agenda 2030 para el Desarrollo Sostenible. Con un enfoque de derechos y poniendo a las personas en el centro busca el desarrollo sostenible global dentro en los limites planetarios. Por ello entre sus recomendaciones para alcanzar este ODS se encuentra la gestión integrada de los recursos hídricos en todos los niveles mediante una cooperación transfronteriza.

Los recursos hídricos se encuentran bajo una presión sin precedentes debido al crecimiento poblacional en gran parte de los países, lo que ha incrementado la demanda de agua para consumo humano y actividades productivas, particularmente la actividad agrícola, comprometiendo la disponibilidad del agua para el 2030. Por su parte, el cambio climático a colocado estrés hídrico alterando los ciclos hidrológicos que a su vez comprometen la disponibilidad del agua. De continuar con estas tasas de consumo, la seguridad hídrica se verá cada vez más comprometida y los primeros en sufrir ya sus consecuencias son los países más pobres y en particular las poblaciones que residen en las deltas fluviales.

De acuerdo con el Banco Mundial la escasez de agua afecta a más de $40 \%$ de la población mundial, por lo que su objetivo es ayudar a los países a garantizar la sostenibilidad del uso del agua, desarrollar la resiliencia climática y fortalecer la gestión integrada de los recursos hídricos conducirá a la seguridad hídrica.

Este libro sobre las "Dimensiones sociales y económicas del uso del recurso hídrico” toma tres importantes temas de discusión: el derecho humano al medio ambiente, agua, enfoques sistemáticos y 
aproximación económica. De este modo, ofrece tres perspectivas para abordar el marco legal y fortalecimiento institucional, la importancia de la definición del agua desde diferentes ángulos y finalmente desde el punto de vista económico como se define y estudia el agua dada su escasez y en consecuencia necesaria gestión. 


\section{INTRODUCCIÓN}

T a seguridad de la humanidad responde a la necesidad imperante Lde salvaguardar el medio ambiente en el que se encuentran inmersos diversas especies que congregan acciones específicas para un fin determinado, esa acción concreta vincula un hecho social que acontece en diversas manifestaciones de acuerdo a las necesidades e intereses predispuestos, parte de esos intereses hoy día es el hecho o fenómeno social que reside en particular con el recurso natural del agua.

El recurso hídrico en el siglo XXI representa un paradigma para la sobrevivencia del ser humano, atendiendo a un ritmo acelerado su demanda mundial. Como tal, es un recurso natural limitado que por tanto resulta ser escaso, estimado y sobrevalorado.

Ante tal situación, el interés que adquiere resulta ser prioritario a nivel mundial por lo que a partir del principio de necesidad y seguridad ha emergido control y poder por este recurso susceptible de conflictos latentes, emergentes o manifiestos entre países y naciones por su uso, disponibilidad y distribución.

Diversos autores ${ }^{1}$ han señalado el agua como el "oro azul" que en el siglo XXI y este nuevo milenio manifiesta mayores

1 Véase Vandana, Shiva, en Las guerras del agua, en donde nos aboca a la interrogante del ¿por qué? de las guerras mundiales, que no van más allá de los recursos naturales mediante el binomio escases-necesidad, como punto de partida para el derecho al acceso, así como el comercio que emerge de ese binomio que llega a ser contrario a las culturas de las diversas 
conflictos socio ambientales derivado de su escasez a través de su uso y distribución.

Es a partir del empleo e interés que se le otorga al recurso hídrico, que delimita sus funciones a utilidad individual y/o colectiva; que bien puede beneficiar o perjudicar.

El reto para las sociedades es mitigar, adaptarse, prevenir fenómenos emergentes por circunstancias derivadas del agua en donde el individuo ha tenido participación a través de tomas de decisión.

Factores como el acelerado crecimiento de la población detonan escenarios no gratos en las condiciones del manejo integral del recurso hídrico. Otro factor sustancial es el económico visto desde el proceso neoliberal y globalizado en el que estamos inmersos. Creando

sociedades en cuanto a la cosmovisión. Jalife-Rahme, Alfredo, en Las guerras globales del agua, sitúa las guerras del agua por ser un mínimo vital y como aplicación de una economía de potencias mundiales; establece dos puntos de vista el primero refiere a la privatización que se ha hecho del agua a partir de su comercialización y el segundo en cuanto a que como consecuencia de lo anterior surge contrariedad con el enfoque humanista del derecho humano al agua. Asimismo, explica la importancia que tiene el agua para los nuevos enfoques del oro negro específicamente con la fracturación hidráulica (fraking). Ball, Philip en $\mathrm{H} 2 \mathrm{O}$, una biografía del agua; en esta obra relata la vida del agua en los diversos escenarios tales como la ecología, la química, la física, la ambiental, el humano, plasmando así, al igual que los otros autores la situación del conflicto que emerge a partir del uso y distribución que se haga de la mima, sin embargo señala la disponibilidad del agua así como su distribución, en cuanto a que se puede realizar la gestión del agua siempre que se use los medios eficaces que en principio permitan el valor vital de la misma. Sultana, Farhana y Loftus, Alex, en El derecho al agua; describe el contenido sociopolítico, cultural y económico del agua señalando críticamente la situación actual de las naciones respecto al daño al recurso hídrico, en el que no sólo se incube el derecho humano al agua sino se invocan otros derechos que de forma directa e indirecta van implícitos en este. Aguilera Klink, Federico, en La nueva economía del agua; al respecto, este autor ahonda sobre la dinámica de cambio en los contextos social, económico, económico y ambiental, en el que a partir de esos cambios plantea se revaloraren nuevos conceptos y atención pública y política del recurso hídrico a partir de esa nueva concepción esboza la inserción de gestión hídrica, democracia, territorio, participación y consulta pública de forma equitativa en el que se busquen nuevas alternativas de gestión y soluciones de conflictos que se originan por el agua. Aboites Aguilar, Luis, en La decadencia del Agua de la Nación se centra en la descripción de los actores que emergen en los diversos sectores de la sociedad, en la forma de cómo determinan los usos y la administración del agua. Señala históricamente dos aspectos del agua el primero en cuanto a la concepción de la nación respecto al agua determinada a partir de un proceso neoliberal y la segunda como consecuencia de la primera realiza el estudio del agua como modelo mercantil-ambiental en el que se le otorga un valor económico de precio al agua sobrevalorando así un bien vital a un aspecto económico; hace un hincapié en la ciencia e infraestructura mediante las cuales se ha propiciado la expansión y diversificación del agua. 
condiciones del libre mercado en la gestión del agua, financiamiento y presupuesto de los Estados para las acciones de políticas públicas e infraestructura en servicio de agua potable y saneamiento.

De forma sistemática se exponen categorías de análisis desde la perspectiva del "valor agregado" otorgado, empleado en el recurso hídrico. Estos enfoques consienten analizar el recurso hídrico desde la perspectiva, multidisciplinar, transdisciplinar y sociohidrológica.

Hoy los temas ambientales y en específico el agua son temas situados en una realidad compleja, con fenómenos y hechos sociales que desde el ámbito académico y de investigación deben ser de reflexión, generación y aplicación del conocimiento para contribuir en procesos de adaptación, prevención y mejora para el pleno desarrollo de una vida digna y sostenible de todo ser vivo en este planeta.

Esta obra aborda y otorga al lector un bosquejo de enfoques determinantes del recurso hídrico con una mirada sistemática, con el objeto de tener presente el recurso hídrico como una fuente de vida que debe ser comprendida con una visión holística y transversal. 



$$
\text { I. }
$$

\section{Derecho humano al MEDIO AMBIENTE}





\section{Derecho a un medio ambiente sano y ecológicamente equilibrado}

$\mathrm{Z}^{1}$ ser humano es un ser con capacidad racional que manifiesta Ecada una de sus acciones para beneficio propio o común, los medios para poder satisfacer sus intereses y cubrir sus necesidades pueden variar de acuerdo a cada uno de ellos por lo que los recursos naturales representan para él un medio que le permite subsistir, convivir y aprovechar el beneficio que le proporcionan otros seres del medio, aunado a eso le permite manifestarse en una relación con otros individuos de su misma especie los cuales en su conjunto se adaptan al medio en el que se encuentren.

El medio ambiente proporciona al sujeto una serie de elementos naturales primarios y secundarios que alimentan la supervivencia del individuo dentro de una sociedad, permitiéndole ejercer un "poder" sobre el recurso natural que emplea con el objeto de "ser" y "pertenecer" a un grupo social, a una sociedad, a un sector caracterizado por uno o varios factores que influyen a través de la representación y reproducción social ${ }^{2}$.

En la presencia de transición de un período cíclico, en un primer momento el hombre se adaptó a su medio, posteriormente existió una integración entre el individuo y el entorno, más tarde se fue despojando de una visión integradora con su medio, en donde el

2 Dowdor, Ladislau, La reproducción social, 1ra. Ed., México, siglo XXI, 1999, pp. 360-361. 
hombre dejó de adaptarse al mismo, hoy día el hombre acopla el medio natural según sus intereses y necesidades.

Es decir, los grupos humanos pasaron de ser nómadas a sedentarios a través de los asentamientos en diversos contextos que les ofrecía el medio; propiciando una sociedad estructurada ${ }^{3}$ en aspectos sociales, culturales, políticos y económicos, permitiéndoles un desarrollo primitivo a uno cada vez más moderno y sofisticado en el cual la economía empezó a tener una intervención que generó nuevos contextos como el actual modelo económico.

Se ocupó de crear y satisfacer de forma pronta recursos o instrumentos que le concedieran un trabajo menos tardado y con mayor provecho, el cual se fue desarrollando y evolucionando por medio de la ciencia y tecnología creando un escenario de producción dispar entre los aspectos sociales y ambientales.

En ese escenario de producción los retos que afrontan las sociedades refieren a las formas de organización y valoración del sistema; el cual pasa de un medio de producción desaprovechado en recursos naturales a uno en el que en el siglo XXI nos inserta a una integración y convivencia con el medio ambiente de forma directa e indirecta a través de una economía sustentable, una economía denominada por las propias sociedades como una economía verde ${ }^{4}$.

La visión del medio natural como proveedor inagotable a proveedor agotable crea incertidumbre a nivel global ya que las grandes potencias se movilizan a países con zonas que permiten el control y manejo de los recursos naturales y desechos sin control o intervención alguno de las autoridades correspondientes como es el caso de China ${ }^{5}$, país en que por causa de escasa normatividad

3 Weber, Max, Estructuras de poder, 4ta. Ed., México, FONTAMARA, 2012, p. 45.

4 PNUMA describe la economía verde como "aquella economía que resulta en un mejor bienestar humano y equidad social, reduciendo significativamente los riesgos ambientales y las escaseces ecológicas". Puede ser considerada como una que es baja en carbono, eficiente en recursos y socialmente inclusiva. http://www.unep.org/es/rolac/econom\%C3\%ADa-verde y http://www.unep.org/greeneconomy/

5 Los principales problemas contaminantes del medio natural para China son contenido del dióxido de azufre, polvo de la atmósfera superior a la norma establecida por el Estado. Contaminación del agua de ríos, lagos y mares a causa de sustancias tóxicas, el manto freático ha descendido año con año, se ha dañado los bosques, pastos y aguas. Lo anterior, es derivado del empleo de metales pesados y desechos industriales. Recuperado de: Food and Agriculture 
jurídica en lo respectivo a el cuidado, la preservación, la mitigación, la responsabilidad de daño al medio ambiente y los niveles de contaminación son cada vez mayor, a su vez la mano de obra barata da pauta a que diversas empresas se alojen para la producción de mercancía.

Lo que conlleva a la escasa intervención, gestión o acceso a un derecho humano como lo es el medio ambiente sano, que no debe dejar ausente la interdependencia e indivisibilidad con los derechos a la alimentación, el agua potable, la salud, la vivienda entre otros.

Estos aspectos involucran la condición de bienestar y desarrollo para un individuo en caso de alterarse alguno de ellos, se anula o no existe gestión alguna para el acceso de estos elementos vitales en el desarrollo integral del sujeto, habiendo entonces ausencia de obligación por parte del Estado para promover, respetar, proteger y garantizar los elementos mínimos de cada derecho, incluyendo la accesibilidad, la disponibilidad y la adecuación ${ }^{6}$, derechos que integran las obligaciones establecidas en los tratados internacionales.

En el siguiente gráfico se plasma una idea central de la función del individuo, persona o sujeto social desde su origen a lo que podríamos decir su evolución con base al constructo social, económico y ambiental. El gráfico denota la dinámica del individuo de forma particular y colectiva en su proceso de adaptación a su medio conjugada con las estructuras social, cultural, política y económica que sientan la base de las instituciones sociales de hoy día.

Organization of the United Nations (FAO), "China's environment policy", Revista Unasylva, EE.UU., No. 134, vol., 33, 1981.

6 Gómez Trejo, Omar, Los derechos a la alimentación, al agua, a la salud y a la vivienda contenidos en el artículo 4to. Constitucional a la luz del Derecho Internacional de los Derechos Humanos en México, en Ferrer Mac-Gergor Poisot, Eduardo, Caballero Ochoa, José Luis, et. al. Derechos Humanos en la Constitución: Comentarios de Jurisprudencia Constitucional e Interamericana, México, UNAM-Suprema Corte-Konrad Adenauer Stiftung, 2013, p. 582. 


\section{Gráfico 1. Trinomio: individuo-medio ambiente}

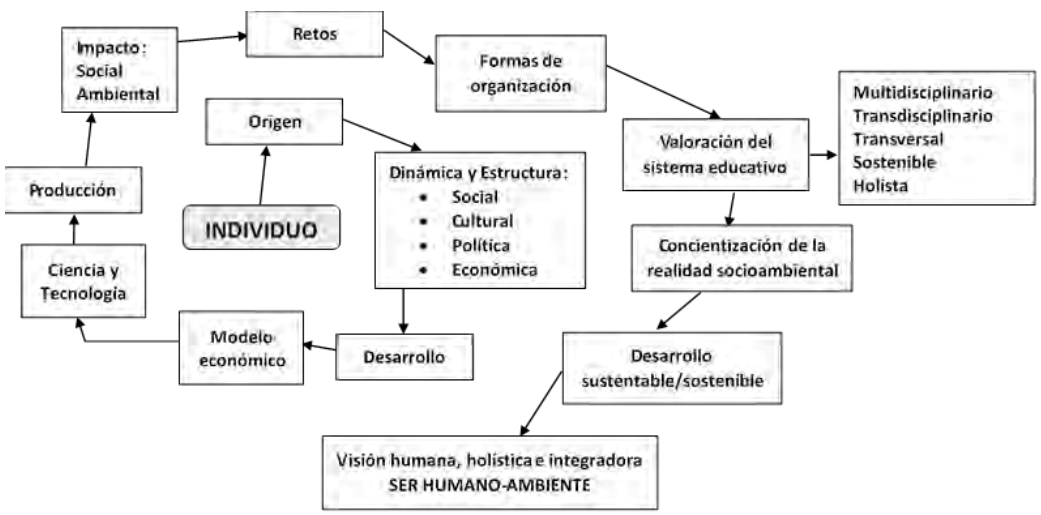

Fuente: Elaboración propia.

El derecho humano a un medio ambiente sano y ecológicamente equilibrado implica factores de vulnerabilidad, daños y violaciones que deben legitimar el acceso a la justicia de forma efectiva.

El reconocimiento y validez de las normas de origen externo e interno dan pauta para conocer, reconocer, ejercer y garantizar el derecho a un medio ambiente sano a través de una justicia transicional ${ }^{7}$ que aborda los conflictos ambientales mediante la inclusión y participación activa de las partes involucradas en los conflictos ambientales.

\section{Medio ambiente sano}

El binomio de la relación ser humano-medio ambiente establece elementos de forma gradual y sustantiva de la interpretación y alcance de lo que se constituye como medio ambiente; el cada vez más complejo panorama global de la repercusión del conflicto

7 Naciones Unidas refiere que la justicia transicional es aquella variedad que conlleva procesos y mecanismos asociados con la intención de la sociedad por resolver problemas o situaciones de conflicto de mediana a gran escala, con el objeto de que los responsables acrediten la responsabilidad de sus actos, exista justicia y se logre la reconciliación. Véase Naciones Unidas, Justicia transicional y derechos económicos, sociales y culturales, Nueva York y Ginebra, 2014, p. 5. 
ambiental en el quehacer físico-biótico, repercute en la integración de una cultura sustentable y por lo tanto en el abordaje y tratamiento de los conflictos de carácter medio ambiental.

En líneas siguiente se describe "medio ambiente" desde el ámbito de competencia internacional y nacional, siendo este el referente de interpretación de análisis del derecho humano al medio ambiente sano que se aborda.

Naciones Unidas lo declara como el conjunto de componentes físicos, químicos, biológicos y sociales capaces de causar efectos directos o indirectos, en un plazo corto o largo, sobre los seres vivos y las actividades humanas ${ }^{8}$. Estos elementos se integran de forma interrelacionada propiciando que sus acciones condicionen la supervivencia de vida en el planeta mismos pueden ser alterados, modificados y/o condicionados por el ser humano a través de las actividades de su quehacer cotidiano.

En 1987 Naciones Unidas ${ }^{9}$ plantea el desarrollo sostenible como aquel "que satisface las necesidades del presente sin comprometer la habilidad de las generaciones futuras para satisfacer sus propias necesidades." Expone de esa manera acciones de responsabilidad en el uso de los recursos naturales.

En México la Ley General del Equilibrio Ecológico y la Protección al Ambiente (LGEEPA) ${ }^{10}$ define al ambiente como el conjunto de elementos naturales y artificiales o inducidos por el hombre que hacen posible la existencia y desarrollo de los seres humanos y demás organismos vivos que interactúan en un espacio y tiempo determinado, refiere un sistema vivo en conjunto dependiente del medio natural.

La enciclopedia de Derechos del Pueblo Mexicano ${ }^{11}$ señala que en el caso del medio ambiente se trata de asegurar el poder disfrutar de

8 Definición derivada de la Conferencia de las Naciones Unidas sobre Medio Ambiente en Estocolmo en el año de 1972.

9 En 1987 la Comisión Mundial del Medio Ambiente y del Desarrollo elabora la definición de desarrollo sostenible. Véase http://www.un-documents.net/wced-ocf.htm

10 Ley Publicada en el Diario Oficial de la Federación el 28 de enero de 1988, texto vigente, últimas reformas publicadas DOF 05-11-2013.

11 Madrazo Jorge y Cottom, artículo $4^{\circ}$, Enciclopedia de Derechos Humanos del Pueblo Mexicano, México a través de sus Constituciones, Tomo1, artículos $1^{\circ}$-15, México, Porrúa, SCJN, IFE, Legislatura Cámara de Diputados, Senado de la República, 2012, p. 551. 
una biosfera con las características físicas y biológicas mínima para una buena calidad de vida. A partir del mínimo se crea un parámetro de aseguramiento de buena o mala calidad de vida determinada en el acceso a disfrutar la biosfera, de forma indirecta lleva a considerar la sostenibilidad de un medio que se integra de factores físicos y biológicos.

El medio ambiente y desarrollo sustentable refiere a la gestión o administración racional y efectiva de todos aquellos recursos naturales que considere de forma activa establecer, mejorar $y$ mantener el bienestar de desarrollo y crecimiento de la población presente sin comprometer la calidad de vida y bienestar de la población futura.

El vínculo entre la sociedad y la naturaleza se establece en dos factores: "el conjunto de las acciones humanas que inciden sobre el sistema ecológico natural y el conjunto de efectos ecológicos generados en la naturaleza y que inciden sobre el sistema social ${ }^{12}$ ".

A los derechos de primera y segunda generación ${ }^{13}$ que caracterizó la modernidad y búsqueda de justicia social como bien supremo del individuo y del ciudadano, se sumó el derecho al medio ambiente como un aspecto base del derecho a una vida digna.

En el marco jurídico internacional en materia ambiental los derechos humanos tienen existencia en la tercera generación ${ }^{14}$ (violaciones a los derechos colectivos) en los cuales se enmarcan la violación del derecho al desarrollo; a disfrutar de un medio ambiente sano y ecológicamente equilibrado; daño ecológico; derecho a disfrutar del patrimonio común de la humanidad; a la paz y a ser diferente; considerándose de carácter colectivo y difuso, por

12 Gallopín, Gilberto, Ecología y ambiente, los problemas del conocimiento y la perspectiva ambiental del desarrollo, México, siglo XXI, 1986, p. 161.

13 Herrera Carrillo, Ricardo, Las corporaciones autónomas regionales y la justicia ambiental, en Justicia Ambiental, las acciones judiciales para la defensa del medio ambiente, Colombia, CAR, 2001, p. 17.

14 La primera generación surge con la Revolución Francesa, constituida por derechos civiles y políticos, siglo XVIII y XIX. La segunda generación surge con la Revolución Industrial, conformada por derechos colectivos económicos, sociales y culturales, siglo XIX y XX. La tercera generación surge con las necesidades constituidas por los derechos de los pueblos o de solidaridad siglo XX y XXI (paz, desarrollo y medio ambiente), engloban los dos derechos civiles, políticos, económicos, sociales y culturales, aunándose los de cooperación entre los pueblos. 
lo cual debe reestructurase o crear nuevas formas alternativas de resolver todos aquellos conflictos que han sido conducidos de forma tradicional en la justicia para trascender a alternativas con criterios de equivalencia.

Los criterios y derechos integrados en la tercera generación de derechos humanos derivan de una serie de factores sociales, económicos, culturales y políticos para el desarrollo y crecimiento de nuevas sociedades; teniendo énfasis a partir de acontecimientos internacionales que dieron pauta a identificar que lo acontecido en un contexto concreto socio ambiental, impacta en otro contexto, siendo que las mismas causas de alteración eran suscitadas por el mismo factor. Por lo que, se considera importante destacar las características que refieren o conceptualizan cada uno de las violaciones y derechos colectivos concernientes al tema ambiental ${ }^{15}$.

Los derechos humanos relacionados con el medio ambiente se encuentran establecidos en los tratados básicos de derechos humanos e incluyen el derecho a un medio ambiente sano y saludable ${ }^{16}$ :

- Derecho a un nivel alto de salud.

15 La LFRA, artículo 2, comprende en el caso del bien colectivo términos que señalan el motivo de la vulnerabilidad, abuso y violación del derecho humano al medio ambiente:

Violación del derecho al desarrollo. Refiere a las conductas de acción u omisión en la que se reprime la participación activa e inclusiva de los pueblos para el desarrollo económico, social, cultural y político de los mismos.

Daño ecológico. Se conceptualiza de acuerdo a las acciones de alteración dolosa o culposa mediante acciones u omisiones.

Daño al ambiente. La Ley Federal de Responsabilidad Ambiental (LFRA) en México señala que es toda aquella pérdida, cambio, deterioro, menoscabo, afectación o modificación adversos y mensurables del hábitat, de los ecosistemas, de los elementos y recursos naturales, de sus condiciones químicas, físicas o biológicas, de las relaciones de interacción que se dan entre éstos, así como de los servicios ambientales que proporcionan. El daño indirecto, se considera aquel daño que en una cadena causal no constituye un efecto inmediato del acto u omisión que es imputado a una persona.

Estado base. Condición en la que se habrían hallado los hábitats, los ecosistemas, los elementos y recursos naturales, las relaciones de interacción y los servicios ambientales, en el momento previo inmediato al daño y de no haber sido éste producido (LFRA).

Al respecto, todo aquel que viole o vulnere ese derecho, será sometido a una acción de alteración dolosa o culposa mediante acciones u omisiones.

16 Cossío Díaz, José Ramón y Meza Fonseca, Emma (coords.), Delitos contra el ambiente u gestión ambiental en el Código Penal Federal, México, Bosch, 2014, p. 46. 
- Derecho a un desarrollo y progreso sustentable ecológico.

- Derecho a una vida digna a partir de un nivel apropiado que considere los básicos de acceso a la alimentación y agua potable.

- Derecho del niño en cuanto a tener un hábitat que le permita un conveniente desarrollo y crecimiento físico y mental.

- Derecho a la participación democrática y equitativa de los ciudadanos para la toma de decisiones concernientes al medio ambiente.

- Derecho a la protección de no discriminación.

- Derecho a la educación e información relativas y vinculadas en salud y medio ambiente.

- Derecho de compartir los avances y progreso científico.

- Derecho a seguridad social.

- Derecho de acceso a la información.

Se trata de concebir el medio ambiente como aquel que deriva del derecho ambiental y que a partir del mismo se vincula con derechos humanos y garantías fundamentales que velan por el interés del bienestar de los ciudadanos.

\section{Justicia ambiental}

La afectación o ausencia de garantizar los derechos humanos en materia ambiental suscitó un abordaje a nivel global que ha ido concretándose en una serie de tratados, cumbres, programas, entre otros, que suponen de forma general y específica la vulnerabilidad del medio ambiente sano para la sociedad en sus diversas dimensiones a partir del principio de justicia ambiental ${ }^{17}$ atendiendo los factores esenciales de explotación y sostenibilidad de la correlación existente entre propiedad-desarrollo sostenible y medio ambiente sano ${ }^{18}$.

17 El concepto de justicia ambiental surge en los años setenta, con base a los movimientos que se oponían a la desigual y racialmente discriminatoria distribución espacial de los residuos peligrosos y las industrias contaminantes en los EE.UU. Véase Ríos Sarmiento, Melissa; Aguirre Fajardo, Alejandra María; Gonzaga Valencia Hernández, Javier, "Desafíos de la justicia ambiental y el acceso a la justicia ambiental en el desplazamiento ambiental por efectos asociados al cambio climático", Revista Luna Azul, núm. julio-diciembre, 2015, p. 335.

18 Boletín Informativo de Justicia Ambiental. Agencia de Protección Ambiental de los Estados Unidos, Administración y Gerencia de Recursos (3103), EPA/200-F-9-004, agosto 1994, Oficina de Justicia Ambiental. La EPA señala que la misión de justicia ambiental 
La Agencia de Protección Ambiental de Estados Unidos (APAEU) $)^{19}$ emplea la justicia ambiental como "el tratamiento justo de personas de todas las razas, culturas, ingresos y niveles educativos con respecto al desarrollo e implementación de leyes, reglamentación y políticas ambientales" este concepto configura equidad e igualdad de acceso en la implementación de la normativa ambiental.

Javier Gonzaga ${ }^{20}$ describe el derecho de acceso a la justicia ambiental por su configuración como derecho autónomo, establecido en un instituto legal dotado de contenido sustancial ${ }^{21}$ y procedimental $^{22}$ que lo hace independiente en su estatuto jurídico pero interdependiente con otros institutos jurídicos que reconocen los derechos humanos afectados como consecuencia del deterioro ambiental y la inequitativa distribución de los recursos que ante tales hechos vulneran o violan derechos y garantías de bien común e individual.

Este tipo de justicia implica tener acceso al mismo ${ }^{23}$, es decir aborda el compuesto de procedimientos administrativos y judiciales

para lograr una razonable protección del ambiente y que ningún sector de la población, no importa su raza, etnicidad, cultura, o ingreso compartan el peso desproporcionado de las consecuencias de contaminantes ambientales. El presidente Clinton firmó el 11 de febrero de 1994, la Orden Ejecutiva 12898, comprometiendo al Gobierno Federal con los principios de Justicia Ambiental. Lo anterior significa un ejemplo de las estrategias de líneas de enlace ambiental que procuran desde el poder ejecutivo asegurar que todas las personas reciban el beneficio total de comunidades limpias y sostenidas.

19 Véase https://espanol.epa.gov/espanol/terminos-j

20 Valencia Hernández, Javier Gonzaga, "El derecho de acceso a la justicia ambiental y sus mecanismos de aplicación en Colombia", tesis doctoral, Universidad de Alicante, 2011, p. 206. 21 Se refiere a lo sustantivo como el conjunto de reivindicaciones políticas y sociales, que se aloja en un entorno ecológico y social de forma inclusiva viéndose desde una perspectiva complementaria y no separada o individualizada, dependientes uno del otro con carácter de sujetos y no como objetos.

22 Lo procedimental recae en el aspecto jurídico el cual establece los derechos de forma material que a su vez determinan los procedimientos que se requieren para reconocerlos en el momento que se vulneren o violen; asimismo funcionan como preventivos al momento de establecer las consecuencias jurídicas que se tiene al momento de existir una conducta o acción que perjudique a otros; funciona como aquel que reconoce los derechos como el de consulta previa, acceso a la información, a un medio ambiente sano, a una vida digna; es decir reconoce todos los derechos individuales y colectivos.

23 Valencia Hernández, Javier Gonzaga, et. al., "Desafíos de la justicia ambiental y el acceso a la justicia ambiental en el desplazamiento ambiental por efectos asociados al cambio climático", Revista Luna Azul, Colombia, núm. 41, julio-diciembre de 2015, pp. 339-340, http:// www.redalyc.org/articulo.oa?id=321739268018 
que protejan, conservan y garanticen la defensa del medio ambiente que se simplifica como derecho ambiental. Este concepto presupone la garantía del derecho ambiental con base a un procedimiento institucionalizado en un sistema estructural-funcional con carácter de poder legítimo.

La justicia ambiental parte no sólo de asegurar la protección de los riesgos medioambientales relativos a la salud y calidad de vida; sino que puedan disfrutar el derecho a vivir en un medio ambiente sano, independientemente de su etnia, género, edad o nivel de ingresos económicos ${ }^{24}$.

Autores como Tower ${ }^{25}$ y Wenz ${ }^{26}$ aplican la justicia ambiental desde el marco de escala humana relacionada a la justicia distributiva; la equidad refleja para ellos, un beneficio común a partir de la participación social y toma de decisiones. Se basa en un proceso singular y plural de equidad y sustentabilidad que debe apoyarse de políticas públicas ${ }^{27}$ que impliquen la sustentabilidad considerando los aspectos sociales, económicos, políticos y culturales.

Este concepto remite a considerar una justicia de visión equitativa, participativa e inclusiva sin exclusión alguna que promueva una justicia preventiva, de mitigación y compensación correspondiente a partir de políticas públicas que en consenso con la sociedad atribuyan medidas acordes a la realidad en la que estén inmersos las estructuras e instituciones sociales.

24 Roblero González, Juan Ángel, et. al., "El acceso a la justicia ambiental y la posibilidad de implantación de tribunales ambientales en Chiapas, México" México, Revista Ra Ximhai, núm. 2, vol. 8, mayo-agosto de 2012, pp. 175-180, http://www.redalyc.org/articulo. oa? id=46123333018

25 Towers, G., "Applying the Political Geography of Scale: Grassroots Strategies and Environmental Justice", The professional geographer, 2000, Vol. 52, Núm. 1, pp. 23-36.

26 Wenz, P.S. Environmental Justice, State University of New York Press, 1988, Albany.

27 Véase Galindo Mendoza, María G., et. al., "Justicia Ambiental. Entre la utopía y la realidad social Culturales" México, Revista Culturales, núm. 1, vol. III, enero-junio de 2015, p. 244, http://www.redalyc.org/articulo.oa?id=69438994008 Los autores consideran que la justicia ambiental debe entenderse como un paradigma complejo, que tutela el uso sustentable de los recursos naturales, vinculándolos a las políticas públicas, para que en éstas se inserten aspectos de protección a los derechos fundamentales relacionados, así como participación de los actores para incidir en el proceso de toma de decisiones y que trascienda en la resolución de problemas ambientales. 


\section{Derecho al agua}

Derivado de la materia de Derecho ambiental respecto al cuidado del medio ambiente a partir de las garantías y su acceso como derecho; resulta de interés prioritario y de seguridad nacional e internacional el derecho al agua a partir del simple hecho de ser parte esencial y vital para todos los organismos que habitan en este planeta.

En cuanto a la visión o perspectiva jurídica hoy día se reconoce como derecho humano el derecho al agua en cuanto al acceso al agua potable ya que al ser un recurso vital y limitado está creando estrés hídrico a nivel global que conlleva a considerar de forma política y gubernamental, políticas públicas que reconsideren la gestión integral del agua.

Resulta entonces que el interés de acceso a este derecho se configura de forma macro mediante los tratados o instrumentos internacionales a una aplicación micro en un contexto nacional, estatal o regional. La comprensión resulta ser compleja ya que implica activar la participación e inclusión activa de la ciudadanía para la toma de decisiones aun cuando mayormente resulta ser un derecho transgredido.

Como ya se ha enunciado este derecho tiene estrecho vínculo con otros derechos humanos, mismos que al momento de presentarse pueden manifestarse con mayor grado de vulnerabilidad o exclusión de acuerdo al grupo social que se trate, por ejemplo, el grupo vulnerable como los pueblos indígenas ${ }^{28}$ son más susceptibles de padecer de menor atención.

En el caso de México es recurrente la violación de derecho a la propiedad, al desarrollo sustentable, libre autodeterminación, identidad cultural, al derecho a la consulta previa de los pueblos y comunidades indígenas ${ }^{29}$ que es una de las mayores causas de

28 Heller, Léo, Me parece que las poblaciones rurales tienen menos prioridad que las urbanas. Los que viven en las periferias tienen menos prioridad que los que viven en la parte central de las ciudades. Los grupos indígenas menos que los no indígenas. Hay cierto patrón de desigualdad o inequidad en el acceso de los servicios. Hay una exclusión de las poblaciones en condiciones más vulnerables. Véase http://www.agua.unam.mx/noticias/2017/nacionales/ not_nac_mayo $14 . h t m l$

29 En el caso de México véase DOF: 12/08/2016. RECOMENDACIÓN General No. 27/2016 sobre el derecho a la consulta previa de los pueblos y comunidades indígenas de la República Mexicana. http://www.dof.gob.mx/nota_detalle.php?codigo=5447796\&fecha=12/08/2016 
conflicto manifiesto debido a que los pueblos indígenas no son considerados para la toma de decisiones concerniente al modelo de desarrollo que desean.

\section{Normas de origen externo}

Uno de los aspectos vitales enmarcados dentro del medio ambiente sano y equilibrado es el recurso hídrico el cual es de importancia para la sobrevivencia de las especies en todos los ecosistemas.

Enunciar la importancia del derecho al agua supone la apertura de un panorama de derechos que permite el acceso de forma directa e indirecta para el fortalecimiento y vínculo de otros, persistiendo la dependencia tácita de este derecho.

$\mathrm{Al}$ respecto es necesario resaltar el valor que se tiene y la garantía que se puede llegar a concebir a través de los instrumentos internacionales del derecho al agua de grupos vulnerables debido a que en ocasiones se invoca circunstancia y/o factores endógenos y exógenos que alteran las relaciones sociales y por consecuencia en las conductas y acciones manifestadas en su forma de vida, originando nuevos escenarios derivado de los procesos de vulnerabilidad o riesgo.

Con esos procesos se conjugan otros aspectos de las garantías de un medio ambiente sano, el desarrollo de una vida digna para las personas de forma sustentable e integral.

Otros derechos vulnerados de la comunidad indígena son la toma de decisiones; el acceso a la información; el derecho a un medio ambiente sano; la prevalencia de mantener sus orígenes ya que parece ser un atentado contra su cultura que pone en riesgo la desaparición de la misma, así como el derecho al libre desarrollo; entre otros.

Por tal motivo, se considera necesario enunciar todos aquellos instrumentos de origen internacional, que permitan considerar lo establecido en los mismos y con fundamento en ello se puedan abordar aspectos esenciales que garanticen al derecho al agua; así como manifestar o invocar el acceso de todo aquel derecho que no sea respetado y por consecuencia vulnere o ponga en riesgo la 
permanencia de alguna comunidad indígena o en su caso que no exista el cuidado del medio ambiente de forma sostenible.

\section{Instrumentos internacionales}

El primer instrumento internacional es el establecido en el sistema universal de protección de Derechos humanos, en la Declaración Universal, artículo 25, reconociendo de forma implícita el derecho al agua $^{30}$. "Toda persona tiene derecho a un nivel de vida adecuado que le asegure, así como a su familia, la salud y el bienestar, y en especial la alimentación".

La Declaración da pauta para establecer la importancia de la "soberanía permanente sobre los recursos naturales"31 en el que la misma no debe comprometerse por nada que no vaya afín a los valores y bien común de la propia sociedad; el ejercicio de la soberanía deberá responder de forma integral, sustentable y equitativa al desarrollo ${ }^{32}$.

30 Declaración Universal de los Derechos Humanos Asamblea General de las Naciones Unidas Aprobada el 10 de diciembre de 1948.

Artículo. - 25. 1. Toda persona tiene derecho a un nivel de vida adecuado que le asegure, así como a su familia, la salud y el bienestar, y en especial la alimentación, el vestido, la vivienda, la asistencia médica y los servicios sociales necesarios; tiene asimismo derecho a los seguros en caso de desempleo, enfermedad, invalidez, viudez, vejez u otros casos de pérdida de sus medios de subsistencia por circunstancias independientes de su voluntad. 2. La maternidad y la infancia tienen derecho a cuidados y asistencia especiales. Todos los niños, nacidos de matrimonio o fuera de matrimonio, tienen derecho a igual protección social.

31 Resolución 1803 (XVII) de la Asamblea General de la ONU del 14 de diciembre de 1962, Declara lo siguiente:

1. El derecho de los pueblos y de las naciones a la soberanía permanente sobre sus riquezas y recursos naturales debe ejercerse en interés del desarrollo nacional y del bienestar del pueblo del respectivo Estado.

[...]

7. La violación de los derechos soberanos de los pueblos y naciones sobre sus riquezas y recursos naturales es contraria al espíritu y a los principios de la Carta de las Naciones Unidas y entorpece el desarrollo de la cooperación internacional y la preservación de la paz.

32 Declaración sobre el Derecho al Desarrollo adoptado por la Asamblea General de las Naciones unidas el 4 de diciembre de 1986.

...Recordando además los acuerdos, convenciones, resoluciones, recomendaciones y demás instrumentos pertinentes de las Naciones Unidas y de sus organismos especializados relativos al desarrollo integral del ser humano y al progreso y desarrollo económicos y sociales de todos los pueblos, incluidos los instrumentos relativos a la descolonización, la prevención de discriminaciones, el respeto y la observancia de los derechos humanos y las libertades fundamentales, el mantenimiento de la paz y la 
La soberanía y el desarrollo se deben ejecutar en conjunto con la libre determinación y desarrollo económico, social y cultural teniendo la facultad a disponer de sus recursos naturales; vislumbrándose entonces las acciones de participación activa y democrática que han de ejercerse con el fin único de alcanzar y satisfacer el nivel de vida adecuado así en lo competente a la alimentación, salud, educación, vivienda, etc.; esta consideración permite satisfacer intereses propios y colectivos aprovechando adecuadamente sus recursos naturales ${ }^{33}$.

seguridad internacionales y el ulterior fomento de relaciones de amistad y cooperación entre los Estados de conformidad con la Carta.

Recordando el derecho de los pueblos a la libre determinación, en virtud del cual tienen derecho a determinar libremente su condición política y a realizar su desarrollo económico, social y cultural,

Recordando también el derecho de los pueblos a ejercer, con sujeción a las disposiciones pertinentes de ambos Pactos internacionales de derechos humanos, su soberanía plena y completa sobre todos sus recursos y riquezas naturales.

$\ldots$

Artículo 1

1. El derecho al desarrollo es un derecho humano inalienable en virtud del cual todo ser humano y todos los pueblos están facultados para participar en un desarrollo económico, social, cultural y político en el que puedan realizarse plenamente todos los derechos humanos y libertades fundamentales, a contribuir a ese desarrollo y a disfrutar de él.

2. El derecho humano al desarrollo implica también la plena realización del derecho de los pueblos a la libre determinación, que incluye, con sujeción a las disposiciones pertinentes de ambos Pactos internacionales de derechos humanos, el ejercicio de su derecho inalienable a la plena soberanía sobre todas sus riquezas y recursos naturales.

Artículo 2

1. La persona humana es el sujeto central del desarrollo y debe ser el participante activo y el beneficiario del derecho al desarrollo.

2. Todos los seres humanos tienen, individual y colectivamente, la responsabilidad del desarrollo, teniendo en cuenta la necesidad del pleno respeto de sus derechos humanos y libertades fundamentales, así como sus deberes para con la comunidad, único ámbito en que se puede asegurar la libre y plena realización del ser humano, y, por consiguiente, deben promover y proteger un orden político, social y económico apropiado para el desarrollo.

3. Los Estados tienen el derecho y el deber de formular políticas de desarrollo nacional adecuadas con el fin de mejorar constantemente el bienestar de la población entera y de todos los individuos sobre la base de su participación activa, libre y significativa en el desarrollo y en la equitativa distribución de los beneficios resultantes de éste.

33 Pacto Internacional de Derechos Económicos, Sociales y Culturales, Asamblea General de las Naciones Unidas Aprobado 16 de diciembre de 1966, dice lo siguiente:

Artículo 1.1. Todos los pueblos tienen el derecho de libre determinación. En virtud de este derecho establecen libremente su condición política y proveen asimismo a su desarrollo económico, social y cultural. 


\section{En la Declaración Universal sobre la Erradicación del Hambre y la Malnutrición ${ }^{34}$ establece la utilización de recursos marinos y aguas interiores como fuente de alimentos, debiendo preferirse su explotación para el consumo humano, se debe proteger el medio ambiente y realizar la cooperación internacional para la explotación racional de los recursos naturales.}

2. Para el logro de sus fines, todos los pueblos pueden disponer libremente de sus riquezas y recursos naturales, sin perjuicio de las obligaciones que derivan de la cooperación económica internacional basada en el principio del beneficio recíproco, así como del derecho internacional. En ningún caso podrá privarse a un pueblo de sus propios medios de subsistencia.

[...]

artículo 11.1. Los Estados Partes en el presente Pacto reconocen el derecho de toda persona a un nivel de vida adecuado para sí y su familia, incluso alimentación, vestido y vivienda adecuados, y a una mejora continua de las condiciones de existencia. Los Estados Partes tomarán medidas apropiadas para asegurar la efectividad de este derecho, reconociendo a este efecto la importancia esencial de la cooperación internacional fundada en el libre consentimiento.

2. Los Estados Partes en el presente Pacto, reconociendo el derecho fundamental de toda persona a estar protegida contra el hambre, adoptarán, individualmente y mediante la cooperación internacional, las medidas, incluidos los programas concretos, que se necesitan para:

a) Mejorar los métodos de producción, conservación y distribución de alimentos mediante la plena utilización de los conocimientos técnicos y científicos, la divulgación de principios sobre nutrición y el perfeccionamiento o la reforma de los regímenes agrarios de modo que se logren la explotación y la utilización más eficaces de las riquezas naturales.

$[\ldots]$

34 Declaración Universal sobre la Erradicación del Hambre y la Malnutrición. Asamblea General de las Naciones Unidas Aprobada el 16 de noviembre de 1974, se establece lo siguiente:

5. Hoy más que nunca, la utilización de los recursos marinos y de las aguas interiores cobra importancia, como nueva fuente de alimentos y de bienestar económico. Por lo tanto, se deben tomar medidas para promover una explotación racional de estos recursos, preferiblemente para consumo humano directo, con objeto de contribuir a satisfacer las necesidades de alimentos de todos los pueblos.

$\cdots$

9. A fin de asegurar una adecuada conservación de los recursos naturales que se utilizan o podrían utilizarse para la producción de alimentos, todos los países deben colaborar a fin de facilitar la conservación del medio ambiente, inclusive el medio marino.

10. Todos los países desarrollados, y aquellos que estén en condiciones de hacerlo, deberán colaborar técnica y financieramente con los países en desarrollo en sus esfuerzos por ampliar los recursos de tierra y agua para la producción agrícola, y para asegurar un rápido aumento de la disponibilidad, a costo razonable, de insumos agrícolas, como fertilizantes y otros productos químicos, semillas de alta calidad, crédito y tecnología. A este respecto, es también importante la cooperación entre los países en desarrollo. 
Es de carácter vital y de sobrevivencia el cuidado y gestión integral del agua ya que determina un uso racional, aunque lo racional impera en situaciones a veces irracionales; es decir, existe un mínimo de población "consciente" de la importancia del agua en su uso y distribución, el resto de la población realiza una mala gestión del recurso hídrico. Lo que ocasiona escenarios críticos en materia de salud, enfermedades, alimentos debido a que la contaminación del agua no permite su uso para la irrigación de los alimentos y en el caso de las enfermedades suscita reacciones secundarias, cuadros de epidemias o virus.

Continuando con el vínculo de situaciones emergentes en el desarrollo de una vida digna para el individuo, en el Pacto Internacional de Derechos Económicos, Sociales y Culturales, el derecho al agua se establece de manera indirecta, al acordarse de que los Estados partes, reconocen en los artículos 11 y 12, el derecho de las personas a la alimentación, a una adecuada nutrición, protección contra el hambre, y a la salud ${ }^{35}$. Resulta concreto señalar que en

35 Pacto Internacional de Derechos Económicos, Sociales y Culturales, adoptado y abierto a la firma, ratificación y adhesión por la Asamblea General en su resolución 2200 A (XXI), de 16 de diciembre de 1966. Entrada en vigor: 3 de enero de 1976, de conformidad con el artículo 27.

Artículo 11. 1. Los Estados Partes en el presente Pacto reconocen el derecho de toda persona a un nivel de vida adecuado para sí y su familia, incluso alimentación, vestido y vivienda adecuados, y a una mejora continua de las condiciones de existencia. Los Estados Partes tomarán medidas apropiadas para asegurar la efectividad de este derecho, reconociendo a este efecto la importancia esencial de la cooperación internacional fundada en el libre consentimiento.

2. Los Estados Partes en el presente Pacto, reconociendo el derecho fundamental de toda persona a estar protegida contra el hambre, adoptarán, individualmente y mediante la cooperación internacional, las medidas, incluidos los programas concretos, que se necesitan para:

a) Mejorar los métodos de producción, conservación y distribución de alimentos mediante la plena utilización de los conocimientos técnicos y científicos, la divulgación de principios sobre nutrición y el perfeccionamiento o la reforma de los regímenes agrarios de modo que se logren la explotación y la utilización más eficaces de las riquezas naturales;

b) Asegurar una distribución equitativa de los alimentos mundiales en relación con las necesidades, teniendo en cuenta los problemas que se plantean tanto a los países que importan productos alimenticios como a los que los exportan.

Artículo 12. 1. Los Estados Partes en el presente Pacto reconocen el derecho de toda persona al disfrute del más alto nivel posible de salud física y mental.

2. Entre las medidas que deberán adoptar los Estados Partes en el Pacto a fin de asegurar la plena efectividad de este derecho, figurarán las necesarias para: 
relación al desarrollo de la persona en la sociedad se debe contemplar el acceso a los derechos de los artículos antes citados.

La Observación general número 15, al citado Pacto Internacional, artículos 11 y $12^{36}$ reconoce que el agua es un recurso limitado y un bien público fundamental para la vida y la salud. Observación General número 15 "2. El derecho humano al agua es el derecho de todos a disponer de agua suficiente, salubre, aceptable, accesible y asequible para el uso personal y doméstico.

En estas observaciones se declara un estado de alerta o emergente al momento de manifestar el límite de un recurso natural que se consideraba ilimitado, al mismo tiempo se establece como un bien público con el único objeto de satisfacer y cubrir las necesidades básicas inherentes al recurso hídrico.

Sin duda alguna existe un costo por su procesamiento, sin embargo, el aludirlo como un elemento fundamental establece las directrices de cambio de acciones dirigidas a la prevención, tratamiento y soluciones de todas aquellas situaciones vulneradas que se encuentren, dentro de los parámetros de lo salubre, aceptable, accesible y asequible para el uso personal y doméstico.

a) La reducción de la mortinatalidad y de la mortalidad infantil, y el sano desarrollo de los niños;

b) El mejoramiento en todos sus aspectos de la higiene del trabajo y del medio ambiente;

c) La prevención y el tratamiento de las enfermedades epidémicas, endémicas, profesionales y de otra índole, y la lucha contra ellas;

d) La creación de condiciones que aseguren a todos asistencia médica y servicios médicos en caso de enfermedad.

36 Observación General número 15, del Derecho al Agua, artículo 11 y 12 del Pacto Internacional de Derechos Económicos, Sociales y Culturales, $29^{\circ}$ período de sesiones 2002 , numerales siguientes:

1. El agua es un recurso natural limitado y un bien público fundamental para la vida y la salud. El derecho humano al agua es indispensable para vivir dignamente y es condición previa para la realización de otros derechos humanos. El Comité ha constatado constantemente una denegación muy generalizada del derecho al agua, tanto en los países en desarrollo como en los países desarrollados.

[...]

3. En el párrafo 1 del artículo 11 del Pacto se enumeran una serie de derechos que dimanan del derecho a un nivel de vida adecuado, "incluso alimentación, vestido y vivienda adecuados", y son indispensables para su realización. El uso de la palabra "incluso" indica que esta enumeración de derechos no pretendía ser exhaustiva. El derecho al agua se encuadra claramente en la categoría de las garantías indispensables para asegurar un nivel de vida adecuado, en particular porque es una de las condiciones fundamentales para la supervivencia. 


\section{Instrumentos internacionales regionales interamericanos}

En relación a la protección del derecho al agua, se ha reconocido en dos instrumentos internacionales, el derecho a toda persona a tener uso y acceso al recurso hídrico; la primera en la Declaración Americana de los Derechos y Deberes del Hombre y el segundo en el Protocolo Adicional a la Convención Americana sobre Derechos Humanos en materia de Derechos Económicos, Sociales y Culturales "Protocolo de San Salvador."

En la Declaración Americana, se reconoce el derecho al agua de manera implícita en el derecho a la alimentación y como obligación de los padres de cumplir con dicho deber con sus hijos y viceversa cuando los padres lo necesiten ${ }^{37}$.

Se dispone entonces a considerar el cumplimiento de alimentos en términos de abastecer al ser humano con comestibles producidos por el propio individuo, pero dicho alimento demanda del agua para tener los nutrientes y ser un producto consumible; ejemplo de ello es el proceso de riego que abastece a grandes áreas de producción ${ }^{38}$;

37 Declaración Americana de los Derechos y Deberes del Hombre, Asamblea General de la Organización de los Estados Americanos Aprobada el 2 de junio de 1948, se estipula lo siguiente:

Capítulo I Derechos. Artículo 11. Toda persona tiene derecho a que su salud sea preservada por medidas sanitarias y sociales, relativas a la alimentación, el vestido, la vivienda y la asistencia médica, correspondientes al nivel que permitan los recursos públicos y los de la comunidad.

Capítulo II Deberes. Artículo 30. Toda persona tiene el deber de asistir, alimentar, educar y amparar a sus hijos menores de edad, y los hijos tienen el deber de honrar siempre a sus padres y el de asistirlos, alimentarlos y ampararlos cuando éstos lo necesiten.

38 Esta acción es lo que se denomina como huella hídrica, por ejemplo: Cuesta alrededor de 21,000 litros de agua producir $1 \mathrm{~kg}$ de café tostado. Para una taza normal de café, se requieren 7 gramos de café tostado, por lo que una taza de café cuesta 140 litros de agua. Suponiendo que una taza normal de café tenga $125 \mathrm{ml}$, necesitamos entonces más de 1,100 gotas de agua para producir una gota de café. Beber té en vez de café se ahorraría una gran cantidad de agua. Para una taza de té estándar de $250 \mathrm{ml}$ se requieren 30 litros de agua. En el caso la carne de res; una vaca (para producción de carne) es de 3, 100,000 litros. En un sistema de producción industrial de carne, toma en promedio tres años antes de que el animal sea sacrificado para producir unos $200 \mathrm{~kg}$ de carne deshuesada. El animal consume cerca de 1,300 kg de granos (trigo, avena, cebada, maíz, chicharos secos, harina de soya y otros granos pequeños), 7,200 $\mathrm{kg}$ de forrajes (pastos, heno seco, ensilaje y otros), $24 \mathrm{~m} 3$ de agua para beber y $7 \mathrm{~m} 3$ de agua para mantenimiento. Esto significa que, para producir un kilogramo de carne de vacuno deshuesada, utilizamos alrededor de $6.5 \mathrm{~kg}$ de grano, $36 \mathrm{~kg}$ de forrajes y 155 litros de agua (sólo para consumo y mantenimiento. La sola producción de los granos necesarios como alimento requiere de 15,300 litros de agua en promedio. 
así como el proceso de preparación y empaque ${ }^{39}$ de todos aquellos alimentos necesarios de grandes cantidades de litro de agua.

El Protocolo Adicional a la Convención de manera sobrentendida reconoce el derecho a la salud, nutrición y distribución de alimentos ${ }^{40}$. A partir de toda inversión económica, social y política con fortaleza en el aspecto de salud que infiera de forma transversal el interés público, el bienestar físico, mental y social.

39 Esta acción se le conoce como agua virtual, es toda el agua que se necesita para producir, empacar y transportar los bienes y servicios que consumimos. Se dice que es virtual porque no está presente en los productos finales. La Secretaría de Medio Ambiente y Recursos Naturales SEMARNAT, señala que del agua que usamos a diario sólo vemos, tocamos y sentimos aproximadamente el cinco por ciento. Los noventa y cinco restantes es agua virtual y está en nuestros alimentos, ropa, calzado, aparatos electrónicos y todos los productos que usamos en la vida diaria. Ejemplo de la presencia del agua virtual es el microchip de dos gramos para lo cual se requiere de treinta y dos litros de agua; una camiseta de algodón con un peso de $250 \mathrm{gr}$. requiere de dos mil litros de agua.

40 Protocolo Adicional a la Convención Americana sobre Derechos Humanos en materia de Derechos Económicos, Sociales y Culturales "Protocolo de San Salvador", Asamblea General de la Organización de los Estados Americanos Adoptado el 17 de noviembre de 1988.

Artículo 10 Derecho a la Salud. 1. Toda persona tiene derecho a la salud, entendida como el disfrute del más alto nivel de bienestar físico, mental y social.

2. Con el fin de hacer efectivo el derecho a la salud los Estados partes se comprometen a reconocer la salud como un bien público y particularmente a adoptar las siguientes medidas para garantizar este derecho:

a. La atención primaria de la salud, entendiendo como tal la asistencia sanitaria esencial puesta al alcance de todos los individuos y familiares de la comunidad;

b. La extensión de los beneficios de los servicios de salud a todos los individuos sujetos a la jurisdicción del Estado;

c. La total inmunización contra las principales enfermedades infecciosas;

d. La prevención y el tratamiento de las enfermedades endémicas, profesionales y de otra índole;

e. La educación de la población sobre la prevención y tratamiento de los problemas de salud, y

f. La satisfacción de las necesidades de salud de los grupos de más alto riesgo y que por sus condiciones de pobreza sean más vulnerables.

Artículo 11 Derecho a un Medio Ambiente Sano. 1. Toda persona tiene derecho a vivir en un medio ambiente sano y a contar con servicios públicos básicos.

2. Los Estados partes promoverán la protección, preservación y mejoramiento del medio ambiente.

Artículo 12 Derecho a la Alimentación. 1. Toda persona tiene derecho a una nutrición adecuada que le asegure la posibilidad de gozar del más alto nivel de desarrollo físico, emocional e intelectual.

2. Con el objeto de hacer efectivo este derecho y a erradicar la desnutrición, los Estados partes se comprometen a perfeccionar los métodos de producción, aprovisionamiento y distribución de alimentos, para lo cual se comprometen a promover una mayor cooperación internacional en apoyo de las políticas nacionales sobre la materia. 


\section{Instrumentos internacionales del derecho al agua de los grupos vulnerables}

Los instrumentos internacionales en el ámbito universal, establecen diversas reglas que pretenden el acceso al derecho humano al agua. El acceso al derecho al agua se garantiza a diversos grupos vulnerables como son a los 1) los trabajadores y 2) sus viviendas, 3) las mujeres, 4) los menores, 5) los discapacitados, 6) los internos, 7) los menores privados de su libertad, 8) las personas de la tercera edad, 9) los desplazados, 10) los indígenas y 11) toda persona en los términos siguientes:

1) Los Trabajadores ${ }^{41}$ tienen derecho a servicios de salud en el trabajo, de manera independiente de las obligaciones de sus empleadores, tienen el derecho a un ambiente de trabajo que no afecte la salud y a instalaciones sanitarias. Es importante destacar la importancia del acceso al agua para tener una salud adecuada. 2) Las viviendas de los trabajadores ${ }^{42}$ se prevé en las Recomendaciones del Tratado de la Organización Internacional del Trabajo OIT número 115, que deben tener suficiente agua potable, instalaciones sanitarias y adecuado alcantarillado.

41 La Convención de la OIT N 161 de 1985 sobre Servicios de Salud en el Trabajo señala en su Artículo 5, lo siguiente:

Sin perjuicio de la responsabilidad de cada empleador respecto de la salud y la seguridad de los trabajadores a quienes emplea, los servicios de salud en el trabajo deberán asegurar las funciones siguientes...:

(a) $[\ldots]$

(b) vigilancia de los factores del medio ambiente de trabajo y de las prácticas de trabajo que puedan afectar a la salud de los trabajadores, incluidos las instalaciones sanitarias.

42 En la Recomendación de la OIT N 115 de 1961 sobre la Vivienda de los Trabajadores Sugerencias acerca de los métodos de aplicación...

7. Las normas de vivienda mencionadas en el párrafo 19 de los Principios generales deberían referirse, en particular:

(b) al abastecimiento de agua potable dentro de la vivienda del trabajador, en cantidad suficiente para poder cubrir todas las necesidades personales y domésticas;

(c) a los sistemas adecuados de alcantarillado y de evacuación de basuras; ...

8. Cuando la vivienda destinada a trabajadores solteros o a trabajadores separados de sus familias sea colectiva, la autoridad competente debería establecer ciertas normas de habitación que dispongan, como mínimo: ...

(c) que haya suficiente abastecimiento de agua potable;

(d) que existan adecuadas instalaciones sanitarias y de desagüe; ... 
3) La mujer ${ }^{43}$ tiene el derecho de que los Estados Partes de manera obligada adopten las medidas apropiadas para eliminar la discriminación contra la mujer en las zonas rurales de manera que puedan gozar de vida adecuadas como el abastecimiento de agua. En este sentido, el Comité para la Eliminación de la Discriminación contra las Mujeres consideró que este artículo obliga a los Estados parte a tomar todas las medidas apropiadas para asegurar condiciones de vida en relación con el agua y el saneamiento cruciales para la prevención de enfermedades y la promoción de una buena asistencia sanitaria ${ }^{44}$.

4) Los niños ${ }^{45}$ tienen la protección del Estado de garantizar el más alto nivel posible de salud, el cual requiere de manera "crucial para la prevención de enfermedades" del acceso al agua suficiente y salubre. La misma Declaración de los Derechos del Niño, principio $4^{46}$ reconoce que "el derecho de los niños a la

43 En la Convención sobre la Eliminación de todas las Formas de Discriminación contra la Mujer (CEFDM), Asamblea General de las Naciones Unidas Aprobada el 18 de diciembre de 1979, en su Artículo 14 (2) señala lo siguiente:

Los Estados Partes adoptarán todas las medidas apropiadas para eliminar la discriminación contra la mujer en las zonas rurales a fin de asegurar, en condiciones de igualdad entre hombres y mujeres, su participación en el desarrollo rural y en sus beneficios, y en particular le asegurarán el derecho a:

(h) Gozar de condiciones de vida adecuadas, particularmente en las esferas de la vivienda, los servicios sanitarios, la electricidad y el abastecimiento de agua, el transporte y las comunicaciones.

44 Comité para la Eliminación de la Discriminación contra la Mujer, recomendación general $\mathrm{N}^{\circ} 24$ (1999) sobre el artículo 12 de la Convención (la mujer y la salud), párrafo 28).

45 Convención sobre los Derechos del Niño (CDN), Asamblea General de las Naciones Unidas, aprobada el 20 de noviembre de 1989, establece lo siguiente:

Artículo 24. 1. Los Estados Partes reconocen el derecho del niño al disfrute del más alto nivel posible de salud y a servicios para el tratamiento de las enfermedades y la rehabilitación de la salud...

2. Los Estados Partes asegurarán la plena aplicación de este derecho y, en particular, adoptarán las medidas apropiadas para:

(c) Combatir las enfermedades y la malnutrición en el marco de la atención primaria de la salud mediante, entre otras cosas, (...) el suministro de alimentos nutritivos adecuados y agua potable salubre (...)

46 Declaración de los Derechos del Niño Asamblea General de las Naciones Unidas, aprobada el 20 de noviembre de 1959, Principio 4:

El niño debe gozar de los beneficios de la seguridad social. Tendrá derecho a crecer y desarrollarse en buena salud; con este fin deberán proporcionarse, tanto a él como a su madre, cuidados especiales, incluso atención prenatal y postnatal. El niño tendrá derecho 
salud el bienestar, y en especial la alimentación". El Comité de los Derechos del Niño de Naciones Unidas enfatiza que de acuerdo con el artículo $24^{47}$ citado los Estados tienen la responsabilidad de garantizar el acceso a agua potable salubre y que este acceso es particularmente esencial para la salud de los niños pequeños. 5) Los discapacitados ${ }^{48}$ tienen el derecho al trato de igualdad como es el caso del acceso en condiciones de igualdad de las personas con discapacidad a servicios de agua potable y su acceso a servicios, dispositivos y asistencia de otra índole a precios asequibles para atender las necesidades relacionadas con su discapacidad.

6) Los internos y/o reclusos ${ }^{49}$ tienen derecho al acceso al agua para aseo personal, salud y limpieza, así como del acceso al agua potable en el momento que lo requiera.

7) Los menores privados de su libertad ${ }^{50}$ tienen derecho a que las instalaciones en materia de infraestructura donde se hayan, satisfagan las necesidades físicas y en forma aseada.

a disfrutar de alimentación, vivienda, recreo y servicios médicos adecuados.

47 Comité de los Derechos del Niño, Observación General N 7 (2006) sobre la realización de los derechos del niño en la primera infancia, Párrafo 27.

48 Convención sobre los Derechos de las Personas con Discapacidad (CDPD), Artículo 28 Nivel de vida adecuado y protección social que dice así:

1.- $[\ldots]$

2. Los Estados Partes reconocen el derecho de las personas con discapacidad a la protección social y a gozar de ese derecho sin discriminación por motivos de discapacidad, y adoptarán las medidas pertinentes para proteger y promover el ejercicio de ese derecho, entre ellas:

(a) Asegurar el acceso en condiciones de igualdad de las personas con discapacidad a servicios de agua potable y su acceso a servicios, dispositivos y asistencia de otra índole adecuados a precios asequibles para atender las necesidades relacionadas con su discapacidad.

49 En las Reglas Mínimas para el Tratamiento de los Reclusos, numeral 15, dice lo siguiente: 15. Se exigirá de los reclusos, aseo personal y a tal efecto dispondrán de agua y de los artículos de aseo indispensables para su salud y limpieza.

$[\ldots]$

20. (2) Todo recluso deberá tener la posibilidad de proveerse de agua potable cuando la necesite.

50 En las Reglas de Naciones Unidas para la protección de menores privados de libertad, Artículos 34 y 37, que señalan lo siguiente:

Artículo 34. Las instalaciones sanitarias deberán ser de un nivel adecuado y estar situadas de modo que el menor pueda satisfacer sus necesidades físicas en la intimidad y en forma aseada y decente. 
8) Las personas de la tercera edad y sus familias ${ }^{51}$ tienen derecho al acceso al agua suficiente.

9) Los desplazados internos ${ }^{52}$ tienen derecho a una vida digna, de manera que comprende el acceso al agua potable y a servicios de saneamiento indispensables.

10) Los indígenas. La relación de los pueblos indígenas con el agua está estrechamente relacionada no solamente con el acceso al agua, sino a sus tradiciones, usos y costumbres, creencias religiosas, formas de alimentación, conservación del medio ambiente, uso equilibrado del medio, salud, alimentación, cultura entre otros derechos universales no solamente como individuos sino en la mayoría de los casos como comunidades o pueblos indígenas.

La relación entre el recurso hídrico y grupos vulnerables ${ }^{53}$ es estrecha al tener el compromiso en mayor grado el Estado en conjunto con la sociedad de garantizar el acceso al agua como derecho, implica capacitación para participar en los procesos de toma de decisiones;

Artículo 37. Todos los centros de detención deben garantizar que todo menor disponga de una alimentación adecuadamente preparada... Todo menor deberá disponer en todo momento de agua limpia y potable.

51 En los Principios de las Naciones Unidas en favor de las Personas de Edad, se resalta en el numeral 1, lo siguiente:

1. Las personas de edad deberán tener acceso a alimentación, agua, vivienda, vestimenta y atención de salud adecuados, mediante ingresos, apoyo de sus familias y de la comunidad y su propia autosuficiencia.

52 Los Principios rectores de los de los desplazamientos internos, Comisión de los Derechos Humanos de las Naciones Unidas, aprobado el 11 de febrero de 1998, en el Principio 18, señala lo siguiente:

1. Los desplazados internos tienen derecho a un nivel de vida adecuado.

2. Cualesquiera que sean las circunstancias, las autoridades competentes suministrarán a los desplazados internos, como mínimo y sin discriminación, y se cerciorarán de que pueden recibir en condiciones de seguridad:

(a) alimentos indispensables y agua potable; ...

(d) servicios médicos y de saneamiento indispensables.

3. Se tratará en especial de garantizar que las mujeres participen plenamente en la planificación y distribución de estos suministros básicos.

53 Oficina de Naciones Unidas de apoyo al Decenio Internacional para la Acción "El agua fuente de vida" 2005-2015. El derecho humano al agua y saneamiento, Programa de ONU-Agua para la promoción y la comunicación en el marco del Decenio, España, 2010. 
asimismo legitimar la acción de no discriminación a cualquier persona que pertenezca a un grupo vulnerable.

Ante el inminente proceso de globalización prevalecen situaciones complejas que afectan a grupos vulnerables, sociedad civil y diversos ecosistemas, entre otros; aconteciendo de forma recurrente en la vida diaria de las personas dichas conductas que llegan a ser reflejo de una cultura y en dado caso empeorando al momento de aceptar esos procesos o ciclos de vida no aptos como lo es la contaminación de recursos naturales, explotación del agua, contaminación de afluentes de ríos con desechos tóxicos, entre otros.

Es importante resaltar que en relación a grupos vulnerables no existen instrumentos internacionales específicos que protejan el derecho al agua de forma expresa a los pueblos indígenas, sino de manera indirecta, al proteger, los derechos a la propiedad, protección ambiental, subsistencia, preservación cultural, discriminación racial y autodeterminación; sin embargo, existen instrumentos dispersos y generales en los últimos cincuenta años que se han generado respecto a los derechos humanos aplicable a los derechos de los pueblos indígenas, como lo siguiente ${ }^{54}$ :

1948 la Asamblea General de la Organización de los Estados Americanos tomó el primer paso al aceptar el artículo 39 de la Carta Interamericana de Garantías Sociales; la cual establece la protección de vidas y propiedades defendiéndola de la exterminación, opresión y explotación. Así también la OIT en 1989 reconoce el poder de los pueblos indígenas para asumir instituciones propias, formas de vida que adquiere identidad propia dentro del marco de los Estado en que viven.

El Pacto Internacional de Derechos Económicos, Sociales y Culturales ${ }^{55}$, estipula que en "ningún caso podrá privarse a un pueblo de sus propios medios de subsistencia”.

54 Getches, H, David, Derechos de los Pueblos indigenas al agua y normas internacionales, pp. 1 y 2. Internet www.cepal.org.

55 Pacto Internacional de Derechos Económicos, Sociales y Culturales, Adoptado y abierto a la firma, ratificación y adhesión por la Asamblea General en su resolución 2200 A (XXI), de 16 de diciembre de 1966. Entrada en vigor: 3 de enero de 1976, de conformidad con el artículo 27.

Artículo 1.- 1. Todos los pueblos tienen el derecho de libre determinación. En virtud de este derecho establecen libremente su condición política y proveen asimismo a su desarrollo económico, social y cultural.

2. Para el logro de sus fines, todos los pueblos pueden disponer libremente de sus riquezas 
En las Observaciones Generales número 12 al artículo 11 del Pacto Internacional de Derechos Económicos, Sociales y Culturales, del Derecho a la alimentación adecuada, la vulnerabilidad del derecho a la alimentación a los pueblos indígenas que en ocasiones se les impide el acceso físico a sus tierras ancestrales ${ }^{56}$.

En la Observación número 14, del mismo Pacto, establece el disfrute del más alto nivel posible de salud un medio es la higiene ambiental ${ }^{57}$; el derecho al acceso al agua a los pueblos indígenas es claro, en la Observación General número $15^{58}$ dispone en el artículo 1. Numeral 2, del Pacto Internacional de referencia, el derecho de los pueblos a no privársele de sus medios propios de subsistencia, el Comité de Derechos Económicos, Sociales y Culturales, dice lo siguiente:

7.

$[\ldots]$

Tomando nota de la obligación establecida en el párrafo 2 del artículo 1 del Pacto, que dispone que no podrá privarse a un pueblo "de sus propios medios

y recursos naturales, sin perjuicio de las obligaciones que derivan de la cooperación económica internacional basada en el principio de beneficio recíproco, así como del derecho internacional. En ningún caso podrá privarse a un pueblo de sus propios medios de subsistencia.

56 Observaciones Generales número 12 al artículo 11 del Pacto Internacional de Derechos Económicos, Sociales y Culturales, numeral 13, del derecho a la alimentación, dice lo siguiente: 13.

$[\ldots]$

La accesibilidad física implica que la alimentación adecuada debe ser accesible a todos, incluidos los individuos físicamente vulnerables...Son especialmente vulnerables muchos grupos de pueblos indígenas cuyo acceso a las tierras ancestrales puede verse amenazado."

57 Observaciones Generales número 14 al artículo 12 del Pacto Internacional de Derechos Económicos, Sociales y Culturales, numeral 13, del derecho al disfrute del más alto nivel posible de salud, dice lo siguiente:

27.

[...]

A este respecto, el Comité considera que las actividades relacionadas con el desarrollo que inducen al desplazamiento de poblaciones indígenas, contra su voluntad, de sus territorios y entornos tradicionales, con la consiguiente pérdida por esas poblaciones de sus recursos alimenticios y la ruptura de su relación simbiótica con la tierra, ejercen un efecto perjudicial sobre a salud de esas poblaciones.

58 Observaciones Generales número 15 a los artículos 11 y 12 del Pacto Internacional de Derechos Económicos, Sociales y Culturales, del Derecho al Agua, $29^{\circ}$ período de sesiones, 2002. numeral 7 . 
Dimensiones sociales y económicas del uso del recurso hídrico

de subsistencia”, los Estados Partes deberían garantizar un acceso suficiente al agua para la agricultura de subsistencia y para asegurar la de subsistencia de los pueblos indígenas.

11) Toda persona tiene derecho al acceso al agua potable y saneamiento adecuado $^{59}$.

Toda persona que corresponda a un grupo o sector vulnerable tiene mayor necesidad de requerir y tener la prevención de ser atendido a partir de los principios de equidad.

\section{Normas de origen interno}

La fundamentación del derecho al agua en la Constitución Política de los Estados Unidos Mexicanos, se establece en los artículos 4, párrafo 5; 115, fracción III, inciso a); y 122, apartado C, siguientes:

Artículo 4.

[...]

Toda persona tiene derecho al acceso, disposición y saneamiento de agua para consumo personal y doméstico en forma suficiente, salubre, aceptable y asequible. El Estado garantizará este derecho y la ley definirá las bases, apoyos y modalidades para el acceso y uso equitativo y sustentable de los recursos hídricos, estableciendo la participación de la Federación, las entidades federativas y los municipios, así como la participación de la ciudadanía para la consecución de dichos fines.

Artículo 115

III. Los Municipios tendrán a su cargo las funciones y servicios públicos siguientes:

a) Agua potable, drenaje, alcantarillado, tratamiento y disposición de sus aguas residuales...

59 En las Directrices voluntarias en apoyo de la realización progresiva del derecho a una alimentación adecuada en el contexto de la seguridad alimentaria nacional (FAO), en sus numerales siguientes:

3.6 En sus estrategias de reducción de la pobreza, los Estados también deberían conceder prioridad a la prestación de servicios básicos a los más pobres y a la inversión en los recursos humanos, garantizando el acceso universal a ... el agua potable, un saneamiento adecuado ...

$[\ldots]$

8.1 Los Estados deberían facilitar el acceso a los recursos y su utilización de manera sostenible, no discriminatoria y segura de acuerdo con su legislación nacional y con el derecho internacional y deberían proteger los bienes que son importantes para la subsistencia de la población. Los Estados deberían respetar y proteger los derechos individuales relativos a los recursos como la tierra, el agua, ... 
Artículo 122

C. La Federación, la Ciudad de México, así como sus demarcaciones territoriales, y los Estados y Municipios conurbados en la Zona Metropolitana, establecerán mecanismos de coordinación administrativa en materia de planeación del desarrollo y ejecución de acciones regionales para la prestación de servicios públicos, en términos de la ley que emita el Congreso de la Unión.

Para la eficaz coordinación a que se refiere el párrafo anterior, dicha ley establecerá las bases para la organización y funcionamiento del Consejo de Desarrollo Metropolitano, al que corresponderá acordar las acciones en materia de asentamientos humanos; protección al ambiente; preservación y restauración del equilibrio ecológico; transporte; tránsito; agua potable y drenaje; recolección, tratamiento y disposición de desechos sólidos, y seguridad pública.

La pretensión de la Ley encara una serie de acciones que deben ir de la mano con políticas públicas que atiendan cada uno de las presunciones de forma sistemática y en conjunto entre dependencias municipales, estatales y federales; procurando la atención a las demandas y necesidades de la población de forma directa, pero considerando de forma sustentable e integral todos aquellos objetivos globales e instrumentos internacionales enmarcados en el derecho al agua como bien vital.

Por lo anterior, se resalta que todavía existe una brecha crucial en lo que se establece en las normas a lo que se hace de acuerdo a las funciones de las instituciones encargadas de abastecer y otorgar acceso al derecho al agua, por otra parte la poca o nula participación de la población crea acciones de irracionalidad en el uso y gestión del agua; motivo por el cual la sinergia de estos dos aspectos otorga al concepto de violación del derecho humano al agua, los siguientes aspectos o elementos:

A. Acción u omisión por medio de la cual se impide el acceso, disposición y saneamiento de agua para consumo personal y doméstico.

B. Realizada directa o indirectamente por una autoridad o servidor público.

C. Sin fundamentación legal, causando perjuicio a cualquier persona. 


\section{Obligaciones de los estados de garantizar el derecho al agua}

La experta independiente de la ONU, Carina de Albuquerque presentó el Informe sobre la Obligaciones de derechos humanos relacionadas con el acceso al agua potable y el saneamiento ${ }^{60}$ a la Asamblea General de la Naciones Unidas en donde expone las obligaciones que tienen los Estados de garantizar el acceso al derecho al agua, proponiendo las siguientes siete recomendaciones:

1. El acceso universal al agua debe ser progresivo, por lo que los Estados deben adaptar, ajustar y contextualizar los Objetivos de Desarrollo del Milenio, ahora Objetivos de Desarrollo Sostenible en el plano nacional, debiendo los Estados adoptar medidas deliberadas, concretas y selectivas para realizar progresivamente el derecho al agua y saneamiento. Para lograr el cumplimiento de los Objetivos y respeto del derecho al agua, los Estados deben elaborar planes y estrategias nacionales respaldados al más alto nivel político con estrategias de reducción de la pobreza y los marcos de gastos nacionales para asegurar su funcionamiento, sostenibilidad y exhaustividad. Se trata de abordar la situación compleja mediante la transversalidad y actores implicados además de integrar las alternativas para el acceso y garantía del derecho. El saneamiento y el agua se deben considerar prioritarios y reflejarse en las asignaciones de los presupuestos del Estado. Los Estados deben eliminar la discriminación, las desigualdades y la exclusión sistemática de los grupos vulnerables.

2. Cooperación y asistencia internacional. Se requiere planificar de conformidad con las normas y principios de derechos humanos, incluidos los derechos al agua y el saneamiento, así como las obligaciones de derechos humanos relativas a la no discriminación. La asistencia oficial internacional para el desarrollo destinado al sector del agua y el saneamiento debe

60 Informe de la Experta Independiente, Carina de Albuquerque, sobre cuestión de las obligaciones de derechos humanos relacionadas con el acceso al agua potable y saneamiento, ONU, Asamblea General, A/65/254 del 6 de agosto de 2010. Sexagésimo quinto periodo de sesiones. 
ser más selectiva para que llegue principalmente a quienes más la necesitan.

3. Armonización de las metas y los indicadores con los derechos humanos. La formulación de objetivos, metas e indicadores mundiales nuevos o revisados y su adaptación a nivel nacional debe regirse por las normas y los principios de derechos humanos, incluido el contenido normativo de los derechos al agua y el saneamiento, así como por los criterios de la no discriminación, la participación y la rendición de cuentas. En particular, los futuros indicadores deben reflejar los criterios de disponibilidad, seguridad, aceptabilidad, accesibilidad (incluida la fiabilidad) y asequibilidad de conformidad con las normas de derechos humanos. En la recopilación es necesario desglosar los datos relativos a los progresos en función de los diferentes motivos de discriminación: de género y de riqueza.

4. Más allá de los promedios: no discriminación. Los Estados en donde existan regiones con acceso prácticamente universal al agua y el saneamiento no puede ser motivo de complacencia y no deben pasar por alto los focos persistentes de pobreza, sino que deben seguir centrándose en la lucha contra la discriminación y la exclusión sistemáticas.

5. Participación y empoderamiento para obtener información sobre el agua y saneamiento. Los Estados deben promover procesos participativos y empoderar a las personas para que participen activamente en procesos de adopción de decisiones, incluida la utilización de la asistencia para el desarrollo, entre otras cosas venciendo obstáculos como el alto nivel de analfabetismo, las limitaciones relacionadas con el idioma y los obstáculos culturales y físicos. Para lograr una participación significativa es preciso asegurar la plena transparencia. Todas las personas deben tener un acceso pleno y equitativo a la información sobre el agua y el saneamiento, así como a los planes, las políticas y los programas conexos, incluida la utilización de la asistencia para el desarrollo.

6. Enfoques intersectoriales y examen de las causas fundamentales. Los Estados deben afrontar la cuestión del 
agua y el saneamiento de forma global incluyendo las causas subyacentes de la falta de acceso. A estos efectos, son esenciales los enfoques intersectoriales, entre ellos, la integración del saneamiento y el agua en las iniciativas de protección social.

7. Fortalecimiento de la rendición de cuentas a nivel nacional y mundial. Los Estados deben establecer mecanismos accesibles, asequibles, oportunos y efectivos de rendición de cuentas. Es preciso que los mecanismos de rendición de cuentas judiciales y de otra índole estén al alcance de todos a fin de reforzar la rendición de cuentas para la consecución de los Objetivos de Desarrollo Sostenible. Deben realizarse evaluaciones más sistemáticas de las consecuencias para los derechos humanos.

Con el objeto de una mayor comprensión respecto a las obligaciones de los Estados de garantizar el derecho al agua, se presenta el siguiente gráfico en donde involucra al Estado con el individuo en un estado de corresponsabilidad en las obligaciones:

\section{Gráfico 2. Obligaciones del Estado en la garantía del derecho al agua}

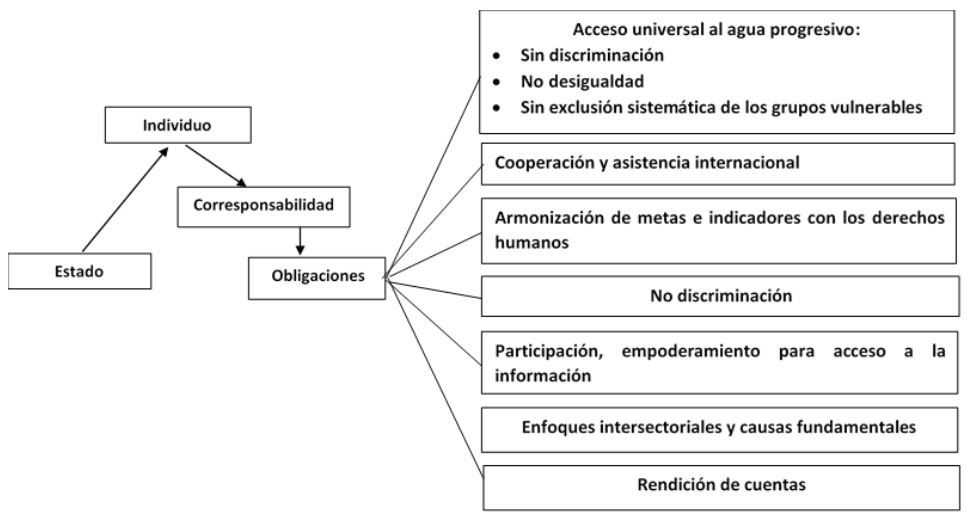

Fuente: Elaboración propia.

Estas obligaciones del Estado deben ejecutarse de forma integral, transparente, equitativa y funcional en un esquema de inclusión y participación social el cual legitime a los actores de la sociedad a 
través del empoderamiento para la toma de decisiones en consenso con el objeto de lograr el bien común y a su vez satisfacer las necesidades e intereses del bien individual.

\section{Buenas prácticas de acceso al agua y saneamiento}

La experta independiente de la ONU, Carina de Albuquerque presentó un Informe sobre la marcha de los trabajos de recopilación de buenas prácticas ${ }^{61}$ a la Asamblea General de la Naciones Unidas en donde expone cinco criterios normativos: disponibilidad, calidad y seguridad, aceptabilidad, accesibilidad y asequibilidad. Asimismo, expone cinco criterios comunes: no discriminación, participación, responsabilidad, repercusión y sostenibilidad.

1. Disponibilidad. El criterio establece que debe estar disponible de forma continua y en cantidad suficiente para satisfacer las necesidades de agua potable y de higiene personal, así como para otros usos personales y domésticos, como cocinar y preparar alimentos, o lavar vajilla y ropa ${ }^{62}$. La cantidad de agua no puede cuantificarse, varía de región en región, condiciones climáticas y condiciones de salud. Las buenas prácticas consisten en que se dé prioridad al uso del agua uso personal y básico, el uso de tecnologías para usar menos.

2. Calidad y seguridad. Existe un sector muy importante de la población mundial que consume el agua de mala calidad lo que afecta la salud y tiene consecuencias en la asistencia a la escuela y el trabajo. Se debe prever que no se contamine el agua evitando enfermedades de origen hídrico. La Guía para la calidad del agua potable la Organización Mundial de la Salud (OMS) define el agua potable como aquella que "no ocasiona ningún riesgo significativo para la salud cuando se consume durante toda una vida, teniendo en cuenta las diferentes vulnerabilidades que pueden presentar las personas

61 Informe de la Experta Independiente, Catarina de Albuquerque, sobre la marcha de los trabajos de recopilación de buenas prácticas, ONU, Asamblea General, A/HRC/15/31/Add. 1 del 1 de julio de 2010. Consejo de Derechos Humanos, $15^{\circ}$ período de sesiones.

62 Comité de Derechos Económicos, Sociales y Culturales, Observación general No 15, párr. 12 a). 
durante las etapas de su vida ${ }^{63}$. Las buenas prácticas son la elaboración de normas jurídicas que supervisen la calidad del agua y métodos higiénicos de almacenamiento de la misma.

3. Aceptabilidad. Las soluciones para el saneamiento y el abastecimiento de agua que son aceptables en un contexto dado difieren, por ejemplo, la higiene personal es una cuestión muy delicada en todas las culturas. Las buenas prácticas consisten en realizar consultas constantes para conocer su percepción de "aceptabilidad".

4. Accesibilidad. El derecho a la accesibilidad consiste en que las barreras que existan para obtener el agua, no afecten de manera que impida su acceso como la distancia. Se puede tener mucha agua, pero está muy lejos y requieren ocupar muchas horas para obtenerla. Por lo que sostiene el Informe que: "las instalaciones de saneamiento deben ser físicamente accesibles para todos en el interior, o en las inmediaciones de cada hogar, institución educativa o de salud, instituciones y lugares públicos y lugar de trabajo" (A/HRC/12/24, párrafo 75). Las buenas prácticas corresponden a casos de mejoramiento de acceso con instalaciones físicas a los discapacitados. Asimismo, la movilización de comunidades para garantizar la seguridad en las instalaciones de agua y saneamiento.

5. Asequibilidad. Consiste en tener acceso al agua, como el estar conectado a una red pública de distribución de agua de manera que el dinero que ocupen las personas para obtener el agua no se convierta en inasequibles. Las buenas prácticas es también el uso de microcréditos para la adquisición de conectarse en las redes de distribución, tarifas con subvenciones.

Estos criterios están reconocidos y establecidos en la norma de origen interno en el caso de México a partir de la Constitución Política, en la cual los refiere como derecho humano para acceso a toda persona. Parten del principio de equidad y distribución con características vitales para su uso, distribución y consumo humano.

63 Organización Mundial de la Salud, Guías para la calidad del agua potable, $3^{\text {a }}$ edición, Ginebra, 2008, pág. 11. 
Los criterios comunes son cinco:

1. La "no discriminación" en la distribución o acceso al agua o saneamiento, es importante tomar en consideración, el Comité de Derechos Económicos, Sociales y Culturales cataloga la discriminación como "toda distinción, exclusión, restricción o preferencia u otro trato diferente que directa o indirectamente se base en los motivos prohibidos de discriminación y que tenga por objeto o por resultado anular o menoscabar el reconocimiento, goce o ejercicio, en condiciones de igualdad, de los derechos reconocidos en el Pacto Internacional de Derechos Económicos, Sociales y Culturales ${ }^{64}$.

2. La "participación" de la población en algunos proyectos de distribución y acceso al agua y saneamiento es un elemento importante en el proceso de abastecimiento el cual está vinculado con los derechos de libertad activa, expresión, asociación, reunión, acceso a la información y transparencia.

3. Responsabilidad. Para hacerla efectiva los Estados deben establecer mecanismos que sean accesibles, no onerosos, rápidos y eficaces ${ }^{65}$. Debe velarse por el acceso a la justicia en términos prácticos, lo que significa que la población debe tener acceso físico y económico, incluso mediante sistemas de asistencia letrada, y debe proporcionarse información en las lenguas vernáculas. El Estado debe asegurarse de que las víctimas de las violaciones tengan derecho a una reparación adecuada, que puede consistir en restitución, indemnización, satisfacción o garantías de que no se repetirán los hechos ${ }^{66}$.

4. Repercusión ${ }^{67}$. Se refiere al examen de repercusiones de ciertas actividades que pueden afectar la disponibilidad

64 Comité de Derechos Económicos, Sociales y Culturales, Observación general N. ${ }^{\circ} 20$ (2009) sobre la no discriminación y los derechos económicos, sociales y culturales, párrafo 7. 65 Comité de Derechos Económicos, Sociales y Culturales, Observación general N. 9 (1998) sobre la aplicación interna del Pacto, párr. 9.

66 Comité de Derechos Económicos, Sociales y Culturales, Observación general N. ํ 15, párr. 55

67 Comité de Derechos Económicos, Sociales y Culturales, Observación general N. ${ }^{\circ}$ 15, Los Estados partes deben adoptar estrategias y programas amplios integrados que dispongan de agua suficiente y salubre, inciso e. 
del agua y en las cuencas hidrográficas de los ecosistemas naturales, como los cambios climáticos, la desertificación, y la creciente salinidad del suelo, la deforestación y la pérdida de biodiversidad.

5. Sostenibilidad. Entraña el concepto de disponibilidad y accesibilidad a largo plazo.

Estas buenas prácticas del acceso al agua y saneamiento conllevan a un estado híbrido de acciones entre diversos actores con el objeto de avanzar en el cumplimiento de los Objetivos de Desarrollo Sostenible. En el siguiente gráfico se plasma los elementos que constituyen los criterios normativos y comunes.

\section{Gráfico 3. Buenas prácticas: agua y saneamiento}

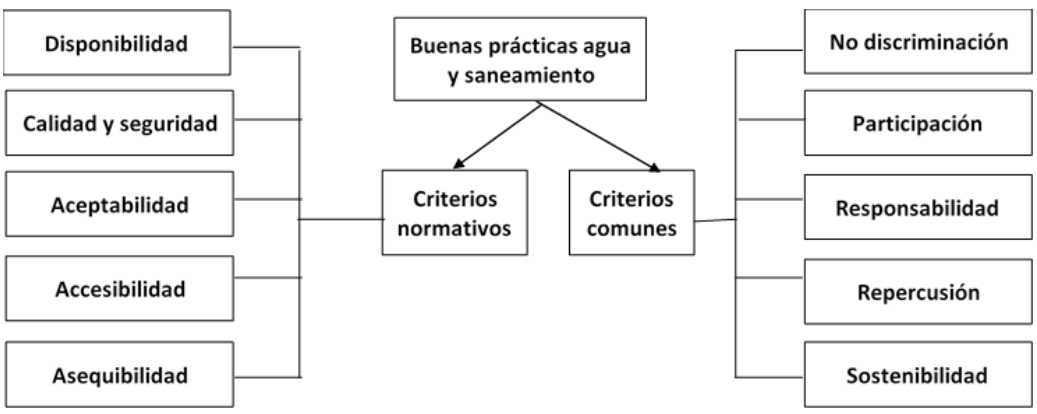

Fuente: Elaboración propia.

De los criterios anteriores prevalecen los valores del sujeto en relación al recurso hídrico, enfocándose en acciones concretas a partir de principios sustantivos para el desarrollo de una vida digna que satisfaga las necesidades básicas de una persona y al mismo tiempo los intereses de bien común de una colectividad en tiempo y espacio. 
II.

Agua.

ENFOQUE SISTEMÁTICO 



\section{Recurso hídrico. Perspectiva transversal}

Derivado de la materia de Derecho ambiental respecto al cuidado del medio ambiente a partir de las garantías y su acceso como derecho; resulta de interés prioritario y de seguridad nacional e internacional el derecho al agua.

El cual es inerte al medio ambiente como parte esencial y vital para todos los organismos que habitan en este planeta.

En cuanto a la visión o perspectiva jurídica hoy día se reconoce como derecho humano el derecho al agua potable ya que al ser un recurso vital y limitado está creando estrés hídrico a nivel global que conlleva a considerar de forma política y gubernamental, políticas públicas que deliberen la gestión integral del agua.

Resulta entonces que el interés de acceso a este derecho se configura de forma macro mediante los tratados o instrumentos internacionales a una aplicación micro en un contexto nacional, estatal o regional. La comprensión resulta ser compleja ya que implica activar la participación e inclusión activa de la ciudadanía para la toma de decisiones aun cuando mayormente resulta ser un derecho transgredido.

Como ya se ha enunciado este derecho tiene estrecho vínculo (interdependencia e indivisibilidad) con otros derechos humanos, mismos que al momento de presentarse pueden manifestarse con mayor grado de vulnerabilidad o exclusión de acuerdo al grupo 
social que se trate, por ejemplo, el grupo vulnerable como los pueblos indígenas son más susceptibles de padecer de menor atención ${ }^{68}$.

En el caso de México es recurrente la violación de derecho a la propiedad, al desarrollo sustentable, libre autodeterminación, identidad cultural, al derecho a la consulta previa de los pueblos y comunidades indígenas ${ }^{69}$ que es una de las mayores causas de conflicto manifiesto, debido a que los pueblos indígenas no son considerados para la toma de decisiones concerniente al modelo de desarrollo que desean ${ }^{70}$.

Las sociedades a través de las instituciones sociales ${ }^{71}$ han cimentando las bases para un desarrollo y evolución como sociedad, esta construcción ha creado escenarios complejos que atienden al sistema económico neoliberal. Es así que los propios sujetos sociales han creado nuevas formas de atender las necesidades básicas con el uso y distribución de los recursos naturales.

El agua como recurso natural ha retomado un valor sustantivo a nivel mundial, este recurso natural dejó de ser visto como tal pasando a ser catalogado con un sin fin de conceptos que consideran su importancia a tal grado de suponerlo de seguridad nacional y mundial, derivado de conflictos latentes pasando a manifestarse de forma emergente ${ }^{72}$.

68 Heller, Léo, Me parece que las poblaciones rurales tienen menos prioridad que las urbanas. Los que viven en las periferias tienen menos prioridad que los que viven en la parte central de las ciudades. Los grupos indígenas menos que los no indígenas. Hay cierto patrón de desigualdad o inequidad en el acceso de los servicios. Hay una exclusión de las poblaciones en condiciones más vulnerables. Véase http://www.agua.unam.mx/noticias/2017/nacionales/ not_nac_mayo14.html

69 En el caso de México véase DOF: 12/08/2016. RECOMENDACIÓN General No. 27/2016 sobre el derecho a la consulta previa de los pueblos y comunidades indígenas de la República Mexicana.

70 Hoy día mediante el proceso de participación del derecho a la consulta previa, libre e informada; las comunidades, localidades, pueblos indígenas y colectivo invocan este derecho para la toma de decisiones.

71 Las instituciones sociales se consideran de acuerdo a la construcción teórica de Durkheim y Weber, las cuales a través de una serie de acciones o hechos sociales van consolidando y formando dichas instituciones como la iglesia, la educación y la familia. Véase las formas elementales de la vida religiosa; las reglas del método sociológico; la división del trabajo social; ensayos sociológicos contemporáneos.

72 Vandana, Shiva, en el libro Las guerras del agua, comenta que la crisis de la misma es la faceta más penetrante, aguda e invisible de la catástrofe ecológica de la Tierra. Cita a Marq De Villiers, Water: the fate of our most precious resource, Nueva York, Houghton Mifflin, 2000, 
El análisis en relación a los conceptos que a nivel nacional e internacional se ha ido acuñando al agua permiten comprender la participación del sujeto e instituciones en la conceptualización de la misma a raíz de su realidad concreta, siendo así que el propio concepto de agua se ha ido modificando en períodos de largo a corto plazo, advirtiendo la participación activa de las instituciones sociales y jurídicas a partir de los años sesenta a la actualidad.

Es así que se identifica un panorama dinámico conceptualizado dirigido por intereses y necesidades que se puntualizan en las líneas siguientes, concediendo así una interpretación y acepción en sentido amplio del concepto que representa el agua.

Pero ¿Por qué abordar el contexto socioeconómico del agua? Cabe puntualizar la necesidad de comprender los hechos a partir del propio sistema, analizando por categorizaciones el significado del agua y la derivación que tiene de forma directa en las sociedades; resultando vinculante la apropiación del significado que se tenga del recurso hídrico para el desarrollo de las sociedades.

Por otra parte, trasciende la importancia de comprender como a partir de un hecho ambiental se concatena con base a las relaciones sociales a circunstancias y contextos sociales y económicos; pasando de ser un hecho meramente ambiental a un hecho socio ambiental en una estructura económica y de poder global. Desde esa naturaleza de las relaciones permite identificar actores, intereses y necesidades que originan el conflicto por el agua.

Es entonces que se analizan aspectos esenciales que dan pautas a las dinámicas socioeconómicas y evolución o transformación de la concepción que se tiene del recurso hídrico de acuerdo a esos cambios suscitados.

Un aspecto esencial ligado como consecuencia de recategorizaciones del recurso hídrico son las nuevas formas de

p.17-18. Robin Clarke, Water: the international crisis, Cambridge, Massachussetts, MITT Press, 1993, p. 67. Los cuales refieren que a partir de finales de los años noventa específicamente en 1998 fueron 28 los países que vivieron la tensión o escasez hídrica, estimando que para el año 2025 aumente el doble, por consecuencia, las personas que habiten lugares con escasez desde 1990 que mantuvo aproximadamente 131 millones de personas, tendrá un aumento severo para el año 2025 aproximadamente de 817 millones de personas; considerando a La India como uno de los países que ingresen a esa tensión o escasez hídrica de forma acelerada. 
gestión integrada llevadas a cabo de forma institucional, esa capacidad reivindicatoria se asemeja a una serie de conductas que la ciudadanía tiene garantizada para hacer valer el acceso, gestión y uso del recurso hídrico a través del marco legal que avala su disposición. En caso de no ser garantizado suscita de forma crítica todos aquellos conflictos que se encuentran en estado latente y que a través del mínimo grado de vulnerabilidad y riesgo se hará manifiesto, suscitando conflictos sociales que pueden desatar hasta un estado de guerra.

A continuación, se describen y analizan conceptos del agua que han sido determinantes para que surjan, permanezcan e incrementen conflictos motivados por el dominio, gestión o distribución del recurso hídrico; teniendo como resultado nuevas formas de vida mediante la energía alternativa, la sustentabilidad, el estrés hídrico o en su caso posicionando a nuevos fenómenos sociales como migración ambiental, desplazamiento forzado interno, entre otros.

\section{El agua en sus diversas categorías}

La manifestación de la conducta irracional de la persona teniendo el mínimo vital o nulo acceso al agua, ha retomado de forma intransigente la necesidad de reconstruir de acuerdo a sus necesidades e intereses el término del recurso hídrico, contemplando esencialmente el aspecto económico, político y a menor escala el aspecto social y ambiental.

Resulta una paradoja humana poder concretar el significado del agua, ya que la realidad no siempre concuerda con lo estimado en la teoría, existe una gran brecha de incongruencia manifestada por el propio ser humano en el que resulta difícil crear y mantenerse en una autonomía individual y colectiva que garantice y satisfaga el cumplimiento o gestión del uso respecto al agua o simplemente tener en principio "acceso" y por consecuencia que ese acceso sea "mínimo" el cual todavía queda vulnerable para que se considere el derecho a una vida digna y de bienestar de acuerdo a lo contemplado por los derechos humanos.

Se desarrollan diversos aspectos que emergen de esta crisis dinámica del recurso hídrico, a partir de posiciones teóricas, institucionales y jurídicas que confronta enfoques y manejos del 
concepto, creando escenarios únicos o con un fin común que tienen por objetivo la sostenibilidad del recurso hídrico en el sistema económico, que no precisamente ampara por dignificar, garantizar y satisfacer el acceso, para el bien público ${ }^{73}$.

\section{Recurso natural}

El agua vista como un recurso natural que conforma el hecho de estar en un mundo de ecosistemas que interactúan entre sí, es un medio de sobrevivencia para muchas especies en sistemas de ciclos de vida, lo que lleva a considerar este recurso natural como premisa mayor de vida de otros organismos.

Provee satisfactoriamente otras fuentes de vida, motivo por el cual adquiere importancia o valor para los organismos dependientes del mismo, sin embargo, el ser humano ha considerado ser la única especie superior a las otras y por lo tanto considerar el recurso hídrico como ilimitado, con el que puede realizar un sinfín de alteraciones para beneficio único del sujeto sin considerar los demás ecosistemas ${ }^{74}$.

La Real Academia Española $(\mathrm{RAE})^{75}$ hace referencia que la palabra agua deriva del latín aqua, el cual es un líquido transparente, incoloro, inodoro e insípido en estado puro, cuyas moléculas están formadas por dos átomos de hidrógeno y uno de oxígeno, que constituye el componente más abundante de la superficie terrestre y el mayoritario de todos los organismos vivos.

Otra forma de identificación es a través de la fórmula química $\mathrm{H}_{2} \mathrm{O}^{76}$, la cual significa que está integrada por dos átomos de

73 Carlos A. Fernández-Jáuregui, considera que para que sea un bien de dominio público se debe de llevar a cabo una gestión multiobjetivo y multidimensional, con la participación de la comunidad, los técnicos y de aquellos que toman las decisiones. Véase Fernández Jáuregui Carlos A., El agua como fuente de conflictos: repaso de los focos de conflictos en el mundo, afters internacionals, núm. 45-46, fundación CIDOB, 1999, p. 180.

74 El sujeto a través de las normas establecidas dispone los recursos naturales al aprovechamiento del ser humano para su beneficio. Ejemplo de ello es la Ley General del Equilibrio Ecológico y la Protección al Ambiente, Artículo 3, fracción XXX, Recurso natural: el elemento natural susceptible de ser aprovechado en beneficio del hombre. El elemento natural es considera en la misma ley y artículo, fracción XV, como los elementos físicos, químicos y biológicos que se presentan en un tiempo y espacio determinado sin la inducción del hombre

75 Real Academia Española, edición 23, año 2019.

76 Se puede decir que, a partir de la construcción e identificación de su fórmula química 
hidrógeno unidos a uno de oxígeno; la unión forma una molécula, un grupo de átomos en forma de un compuesto, asociación de átomos, los cuales son divisibles en átomos de naturaleza distinta. El hidrógeno y el oxígeno son elementos, debido a que contienen un solo átomo, entonces no existe un "átomo del agua", sino una molécula de agua, compuesta por dos tipos diferentes de átomos ${ }^{77}$ en el que deriva de él un ciclo hidrológico el cual traslada el agua en diversas manifestaciones como corrientes, ríos y océanos; así como tres estados, sólido, líquido y gaseoso; cualquiera de estos tres estados depende de la temperatura en la que este expuesta.

El International Glossary of Hydrology ${ }^{78}$ define el agua como la fase líquida de un compuesto químico formado aproximadamente por dos partes de hidrógeno y una parte de oxígeno, en peso. En relación al agua dulce señala que es aquella que tiene baja concentración de sales, o generalmente considerada adecuada para producir agua potable.

El agua ha sido el factor que creó en el planeta las condiciones para la vida y es directa e indirectamente el sustento de todas las formas de vida. Se considera vida, derivado de la importancia como recurso único y primigenio ${ }^{79}$ es un elemento de la naturaleza integrante de ecosistemas, fundamental en el mantenimiento y reproducción de la vida, debido a que integra el desarrollo de los procesos biológicos de todo ser vivo ${ }^{80}$. Este vital líquido interviene de forma trascendental

realizada por el ser humano, recae la primera intervención de conceptualización hacia el recurso hídrico.

77 Ball Philip, H2O una biografía del agua, Fondo de Cultura Económica, trad. de José Aníbal Campos, México, FCE TURNER, 2010, pp. $26-28$.

78 International glossary of hydrology. World meteorological organization, WMO-No.385, UNESCO, p. 370. Describe de forma sustantiva el agua y plasma cuarenta tipos de agua, las cuales son: agua ácida; adhesiva; absorbida; blanda; bruta; capilar; continental; de bebida; de descarga; de formación; de gravedad; de poro; del suelo; distrófica; dulce; dura; estancada; fósil; gravitacional; higroscópica; interlaminar; intersticial; juvenil; libre; magmática; metamórfica; mineral; móvil; muerta; pelicular; pesada; potable; primitiva; salobre; subenfriada; subterránea; superficial; suspendida; turbia; vadosa; aguacero; aguanieve; aguas abajo; altas; arriba; bajas; negras; para baño; residuales y filtrante.

79 Mancisidor, Mikel, El derecho humano al agua: situación actual y retos de futuro, España, Ed. Icaria, 2008, p. 22.

80 Monge, Cristina, La naturaleza del agua como recurso, perspectiva social, económica e institucional de una gestión integral, Congreso Ibérico sobre gestión y planificación del agua, Tortosa, diciembre, 2004. 
en el proceso de la fotosíntesis de las plantas y significa el hábitat de una gran diversidad de seres vivos.

García Aniza ${ }^{81}$ considera que es un recurso naturalmente necesario, limitado y como resultado de la acción humana es un recurso escaso.

Es precisamente que la acción humana del individuo ha permeado el interés del uso en el agua ${ }^{82}$ a partir de los diversos usos y gestiones que se hacen de la misma se derivan una serie de conceptos o percepciones que se reproducen en esa dinámica del aprovechamiento hídrico, ocasionando que lo que para uno significa el agua para el otro no signifique lo mismo, existiendo así una diferencia o incompatibilidad de la percepción y aunque haya un parámetro general que plasme el agua como bien común, derecho humano, de seguridad nacional y mundial, etc., estos términos se van determinando de acuerdo a los intereses que cada grupo social establece y para lo que pueda ser aplicado y le sea de mayor satisfacción.

La conceptualización del agua varía entonces de acuerdo al aspecto categórico o contextual del que se encuentre, del interés o visión que se tenga de la misma, las cuales están basadas en el valor agregado que la persona desde su autonomía le otorga y que la colectividad le reconoce; específicamente como a continuación se presenta:

\section{Tabla 1. Enfoque sistemático}

\begin{tabular}{|c|c|c|}
\hline Enfoque & Interés o visión & \\
\hline Químico & $\begin{array}{c}\text { Molécula formada por dos } \\
\text { átomos de hidrógeno y } \\
\text { uno de oxígeno }\end{array}$ & \\
\hline
\end{tabular}

81 García, Aniza, El derecho humano al agua, México, Ed. Trotta, 2008, p. 51.

82 Aquí conviene comentar que los Estados han ido adoptando una política de seguridad econométrica con énfasis a la protección del recurso humano; pero no por el interés superior de protección sino por la importancia que representa en el desarrollo y crecimiento del sector económico ya que dependen de este recurso como materia prima. Véase T. Klare, Michael, Resource wars: the new landscape of global conflict. 


\begin{tabular}{|c|c|c|}
\hline Social & Bien común, bien público & \multirow{7}{*}{ 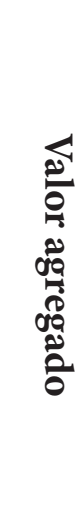 } \\
\hline Cultural & Cosmovisión & \\
\hline Económico & Producto mercantil & \\
\hline Político-gubernamental & $\begin{array}{c}\text { Servicio } \\
\text { Medio de cohesión y } \\
\text { poder }\end{array}$ & \\
\hline Ambiental & Recurso natural y vital & \\
\hline Socio hidrológico & $\begin{array}{l}\text { Multidisciplinariedad en } \\
\text { las ciencias hídricas }\end{array}$ & \\
\hline \multicolumn{2}{|c|}{ Como derecho humano } & \\
\hline
\end{tabular}

Fuente: Elaboración propia.

La definición del agua representa una variabilidad entre intereses y necesidades que determinan dicho concepto; pero que a la vez se conjugan para ir determinando las estructuras y grupos sociales.

Para la civilización humana, el agua es elemental en el sentido de que conforma una parte integral de ésta, una sustancia primordial, dicha relación confiere un valor el cual no puede ignorarse o pasar desapercibido ${ }^{83}$.

Desde el aspecto histórico, es en la revolución industrial donde se concibe de mayor forma la desnaturalización entre el ser humano y la naturaleza se crea y persiste ese dualismo que representa la transformación de la tierra, de bosques, selvas, agua, semillas, de todo aquel recurso nato.

En el año 1972 con los límites del crecimiento, donde en principio se concebía la escasez y agotamiento de los recursos naturales por el uso irracional y abusivo de los mismos; cambia de posición al tratar de hacer un lado esa perspectiva e ir creando una conciencia colectiva en las sociedades basadas en la sostenibilidad y adaptación al medio.

¿Qué se quiere decir con esto? Que en el momento en que se inició un crecimiento económico y formación de grupos de poder,

83 Ball Philip, Op. cit. p. 429. 
el propio sistema económico empezó a manejar formas de pensar en el sentido que esa visión reintegradora del ser humano y su naturaleza fuera vista ahora como un proceso de sustentabilidad y adaptabilidad, siendo que para el año de 1992 con la publicación del libro "más allá de los límites del crecimiento" el discurso cambia, ahora poniendo énfasis en la calidad de vida.

A partir de ahí se concibió y asentó la idea de sustituir los recursos naturales por los químicos, genéticos, de forma tal que esa idea mejora la economía y satisface de forma sustentable para las generaciones presentes y futuras, es decir el permisivo y la aprobación de la sociedad de la ciencia en la naturaleza para su modificación e hizo que existiera una mayor explotación y disfrute de lucro con los recursos.

Sin embargo, al continuar implantando la idea del desarrollo y crecimiento económico de forma "sustentable" con la publicación de "los límites del crecimiento: 30 años después" se ratifica la idea de un crecimiento ilimitado en un mundo de recursos limitados; ahora la tecnología en correlación con la ciencia en pro de esa revolución científica, representa la forma de innovación científica y de implementación de estrategias para ese consumo sustentable.

En el año 2012, en la última edición de los límites del crecimiento, se plantea la preparación de transición inevitable, implementado categorías o indicadores de vulnerabilidad, resiliencia, desarrollo y crecimiento; se afronta entonces la crisis de la naturaleza como tal, pero lo peor de toda esta situación es que todos los términos antes citados se mercantilizaron; lo que conlleva a sistemas de dominio y aceptación que fueron permeando en la conducta y pensamiento del ser humano, se desvinculó de los recursos naturales como algo inerte a él pasando a un proceso de dominio y acaparamiento, en este caso del recurso hídrico a partir de poder tener el control de algo limitado y así establecer estándares económicos para que el resto de la población que es una mayoría, tenga acceso al agua.

Se otorga el enfoque como recurso natural desde su forma innata de no manipulación o intervención por el ser humano, ya que su distribución es irregular a nivel mundial; su ciclo natural es alterado 
de forma directa por la actividad del sujeto y de forma natural hasta cierto grado por el cambio climático ${ }^{84}$.

Estamos conscientes que esta situación se hace cada vez más crítica, la creciente demanda mundial de las materias primas está escaseando, lo que ocasiona las disputas sobre la propiedad de las fuentes de dichos recursos; la demanda a nivel global de los recursos naturales está creciendo a un ritmo insostenible y el crecimiento poblacional un factor determinante ${ }^{85}$.

En este caso el ser humano necesita de agua para poder vivir y el obtener acceso a ella, se está delimitando en una brecha aguda que conlleva el requerimiento de otros recursos para poder sobrevivir, estamos hablando de una cadena de extinción de recursos naturales que afecta de forma directa e indirectamente a mediano y corto plazo la vida y funciones de las sociedades.

Ante esta crisis, el agua concebida como un recurso natural está muy lejana a ser reconsiderada como tal, hoy día surgen nuevas re categorizaciones del concepto de agua en los cuales se van re planteando formas de gestiones, usos y distribución del agua con fines específicos y cada vez más ligados al sistema de mercado, pero paradójicamente con un sentido humano y universal como se describe en los siguientes apartados.

\section{Bien vital}

El agua como bien vital reitera la figura del ser humano como un ser dependiente de la misma y que sin ella simplemente no sobreviviría. De este recurso natural se derivan una serie de necesidades que se articulan como derechos fundamentales para el desarrollo de una vida digna; su vulnerabilidad y escasez dan pauta a procesos de adaptación o resiliencia de las sociedades, motivo por el cual se encuentra reconocido en instrumentos internacionales y nacionales.

84 Céspedes Hernández, Juan José, Pobreza y escasez de agua, en el México del siglo XXI, México, Novum, 2011, p. 127.

85 Klare T., Michael, Resource wars: the new landscape of global conflict, owl books, The United States of America, 2002, p. 15. 
En la Declaración Universal de Derechos Humanos, aprobada por la Asamblea General de Naciones en 1948, en el artículo 25.1 se proclama que

Toda persona tiene derecho a un nivel de vida adecuado que le asegure, así como a su familia, la salud y el bienestar, y en especial la alimentación, el vestido, la vivienda, la asistencia médica y los servicios sociales necesarios; tiene asimismo derecho a los seguros en caso de desempleo, enfermedad, invalidez, viudez, vejez u otros casos de pérdida de sus medios de subsistencia por circunstancias independientes de su voluntad.

El recurso hídrico se plantea como un factor para el acceso al nivel de vida adecuado.

En el Pacto Internacional de Derechos Económicos, Sociales y Culturales, artículo 11.1 se reconoce el derecho de toda persona

(...) a un nivel de vida adecuado para sí y su familia, incluso alimentación, vestido y vivienda adecuados, y a una mejora continua de las condiciones de existencia. Los Estados Partes tomarán medidas apropiadas para asegurar la efectividad de este derecho, reconociendo a este efecto la importancia esencial de la cooperación internacional fundada en el libre consentimiento.

El mínimo vital ${ }^{86}$ encuentra su fundamento en la dignidad humana, la solidaridad, la libertad, la seguridad humana, la igualdad material y el estado social, este derecho se fundamenta en la solidaridad y la libertad considerando que las personas, para gozar plenamente de su libertad, necesitan un mínimo de seguridad económica y de la satisfacción de necesidades básicas.

Carmona ${ }^{87}$ desde el aspecto social del mínimo vital señala como derecho de todos los individuos que forman una comunidad a contar con una cantidad mínima para hacer frente a sus necesidades más básicas.

El mínimo vital de este bien se debe reconocer desde el principio de que el agua ha sido el factor que creó en el planeta las condiciones

86 Diccionario Iberoamericano de Derechos Humanos y Fundamentales, Programa Regional de Apoyo a las Defensorías del Pueblo en Iberoamérica.

87 Carmona Cuenca, Encarna, "Los derechos sociales de prestación y el derecho a un mínimo vital”, Revista Nuevas políticas públicas, España, núm. 2, 2006, p. 184. 
para la vida, es directa e indirectamente el sustento de todas las formas de existencia, es vida, pero sobre todo se le debe considerar como el recurso único y primigenio ${ }^{88}$.

En el año 2004, la Asamblea General de Naciones Unidas en su celebración número cincuenta y ocho a través de la resolución 58/217 ${ }^{89}$ declaró el Decenio Internacional para la Acción (2005-2015) "el agua, fuente de vida" en el cual se le pronunció como un recurso fundamental para el desarrollo sostenible, es decir, representando viabilidad para atender la pobreza, salud y bienestar humano.

Ramón Vargas ${ }^{90}$ propone un cuarto estado del agua además del líquido, sólido y gaseoso, el cual ha denominado como agua-vida, la denomina así con el objeto de que se aplique como algo sagrado desde la concepción de la vida misma, la define de acuerdo al valor biológico, cultural y social de este elemento vital evitando que sea separado de su esencia ética.

Conlleva ponderar el sustento de la misma de forma transversal e inclusiva, el riesgo de su uso de forma contaminada y escasa crea condiciones inexistentes e inclusive de extinción del propio ser humano.

Ladislaw Dowbor ${ }^{91}$ considera que el agua es vital y que se está convirtiendo en un elemento clave del proceso, su ausencia o contaminación conduce a la reducción de los espacios vitales y ocasiona, además de inmensos costos humanos, una pérdida global de la reproducción social, la considera vital debido a las dinámicas derivadas de los procesos que causan ausencia o contaminación originando reducción de los espacios vitales y descomunales costos humanos que conlleva pérdida global de la reproducción social.

De acuerdo a la simplificación del bien vital, se considera como premisa constitutiva y generativa de la vida, simplemente es un

88 UNESCO, El derecho humano al agua: situación actual y retos de futuro, Barcelona, Icaria, 2008, p. 21.

89 Naciones Unidas, resolución aprobada por la Asamblea general, 9 de febrero de 2004, quincuagésimo octavo período de sesiones, 58/217, decenio internacional para la acción "el agua, fuente de vida", 2005-2015.

90 Vargas, Ramón, "Territorios del agua-vida: cultura y democracia”, en Cultura del agua en México, México, MAPORRUA, 2012, p. 27.

91 Dowbor, Ladislaw, La reproducción social, México, Ed. Siglo XXI, 1999, p. 177. 
medio de vida ${ }^{92}$ fundamental para la misma, por lo tanto, es vital para un desarrollo más inclusivo y sostenible.

Lo anterior, significa que el mínimo vital para el nivel de vida digno debe favorecer el acceso que se precisa entre cincuenta y cien litros de agua por persona al día para satisfacer las necesidades humanas básicas; que la fuente de agua debe situarse a no más de un mil metros del hogar; que el coste del agua no debería superar el tres por ciento de los ingresos de la unidad familiar y que el tiempo necesario para el acopio de agua no debe exceder los treinta minutos $^{93}$.

Estos aspectos a la fecha de hoy resultan situaciones de debates ya que desde 1968 a 2016 (aproximadamente cinco décadas) el crecimiento poblacional y los factores de modelos políticos y económicos han hecho que este derecho humano, sea cada vez más carente aun contando que es un recurso limitado.

Para el año de 1968 la población mundial era tres mil quinientos millones de habitantes, para el año 2015 la población mundial pasó a ser aproximadamente siete mil trescientos millones de habitantes, se estima que para el año 2030 ascienda a ocho mil quinientos millones y para el 2050 sea aproximadamente nueve mil millones de habitantes en el mundo ${ }^{94}$ lo que elevará la población mundial por encima de diez mil millones de habitantes en este siglo afectando severamente el acceso diversos derechos humanos inherentes al desarrollo de una vida digna y adecuada así como en los indicadores de pobreza, desigualdad, alimentos, educación y salud, acrecentando esta crisis con una población envejecida ya que el treinta y cuatro por ciento de la población tendrá más de sesenta años para el 2050.

Considerar el agua como bien vital conlleva a un contraste de realidades principalmente si partimos del desarrollo sustentable ${ }^{95}$,

92 Veraza, Jorge, Economía y política del agua, México, Itaca, 2007, p. 16.

93 Estos índices son los establecidos de acuerdo a la Organización Mundial de la Salud y el Programa de Naciones Unidas para el Desarrollo PNUD.

94 United Nations, Department of Economics and Social Affairs, Population Divison, World Population Prospects: The 2015 Revision, Key Findings and Advance Tables. New York, 2015, pp. 1-59.

95 Se define el desarrollo sostenible como la satisfacción de las necesidades de la generación presente sin comprometer la capacidad de las generaciones futuras para satisfacer sus propias necesidades. Informe: Nuestro futuro común, Comisión Mundial sobre el Medio Ambiente y 
es decir ¿cómo lograr la sustentabilidad con un recurso limitado? ¿Cuántas necesidades deben ser satisfechas? ¿a cuántos? ¿por cuánto tiempo?

Se parte de la nula conciencia, caso omiso y aceptación de la mayoría de las sociedades de esta problemática. Se retoma el conocimiento de que el planeta Tierra formado en su mayoría por agua, constituido por un treinta por ciento de tierra y setenta por ciento de agua, de la cual el noventa y ocho por ciento es agua salada y el tres por ciento es agua dulce ${ }^{96}$ este tres por ciento ya se encuentra en un estado crítico para poder satisfacer las necesidades básicas de los aproximadamente siete mil millones de personas.

Se ha comentado que del derecho al agua se derivan otros para su subsistencia tales como la alimentación, la vivienda y la propia vida; existe entonces la búsqueda de proporcionalidad de todos estos derechos para la persona ${ }^{97}$. El agua hoy día se atiende de acuerdo

el Desarrollo, 1987.

96 De acuerdo al Sistema Nacional de Información del Agua (SINA), el país con mayor capacidad de almacenamiento per cápita es Canadá con 26, 778.3 m3/hab, México se ubica en el lugar 10 con una capacidad per cápita de $1,188.7 \mathrm{~m} 3 / \mathrm{hab}$. Ver anexos 1, 2 y 3 .

97 Naciones Unidas, Asamblea General, Resolución aprobada por la Asamblea General el 27 de julio de 2012, 66/288. El futuro que queremos. Sexagésimo sexto período de sesiones. Manifiesta que el agua no sólo como recurso natural debe conservarse, aunado a eso representa para todos los sectores la fuente de su permanencia; así como las formas de gestión y conservación que debe tener. Al respecto se señalan en el anexo:

119. Reconocemos que el agua es un elemento básico del desarrollo sostenible pues está estrechamente vinculada a diversos desafíos mundiales fundamentales. Reiteramos, por tanto, que es importante integrar los recursos hídricos en el desarrollo sostenible y subrayamos la importancia decisiva del agua y el saneamiento para las tres dimensiones del desarrollo sostenible. 120. Reafirmamos los compromisos contraídos en el Plan de Aplicación de las Decisiones de Johannesburgo y en la Declaración del Milenio de reducir a la mitad, para 2015, la proporción de personas sin acceso al agua potable y a servicios básicos de saneamiento y de elaborar planes de ordenación integrada y aprovechamiento eficiente de los recursos hídricos, asegurando el uso sostenible de esos recursos. Nos comprometemos a hacer efectivo progresivamente el acceso al agua potable y a servicios básicos de saneamiento para todos, por ser necesario para lograr la erradicación de la pobreza y el empoderamiento de las mujeres y para proteger la salud de los seres humanos, y a mejorar significativamente la ejecución en todos los niveles, según proceda, de la ordenación integrada de los recursos hídricos. En este sentido, reiteramos nuestro compromiso de apoyar esos esfuerzos, especialmente en favor de los países en desarrollo, mediante la movilización de recursos de todas las fuentes, la creación de capacidad y la transferencia de tecnología. 121. Reafirmamos nuestros compromisos relativos al derecho humano al agua potable y el saneamiento, que ha de hacerse efectivo gradualmente en beneficio de nuestra población, respetando plenamente 
al término de gestión integrada de recursos hídricos que procura atender el uso y distribución de forma equitativa, de esto se hablará más adelante.

El tiempo y espacio son factores determinantes para el acceso al agua, las políticas públicas de abastecimiento y acceso al mismo determinan la equidad de la misma, países como Colombia ${ }^{98}$ sitúan su contexto y delimitan la gestión del uso y distribución a su propio mínimo vital establecido ${ }^{99}$. A diferencia de México se ubica en el lugar veinticuatro de la capacidad de almacenamiento per cápita con 242.5 $\mathrm{m} 3 /$ hab, es decir casi cinco veces menos de capacidad per cápita; sin

nuestra soberanía nacional. Resaltamos también nuestro compromiso con el Decenio Internacional para la Acción "El agua, fuente de vida", 2005-2015. 122. Reconocemos que los ecosistemas desempeñan una función esencial en el mantenimiento de la cantidad y la calidad del agua y apoyamos las iniciativas de protección y ordenación sostenible de esos ecosistemas emprendidas dentro de las fronteras nacionales de cada país. 123. Subrayamos la necesidad de adoptar medidas para hacer frente a las inundaciones, las sequías y la escasez de agua, tratando de mantener el equilibrio entre el suministro y la demanda de agua, incluidos, según proceda, los recursos hídricos no convencionales, y la necesidad de movilizar recursos financieros e inversiones en infraestructura para los servicios de abastecimiento de agua y saneamiento, de conformidad con las prioridades nacionales. 124. Destacamos que es necesario adoptar medidas para reducir considerablemente la contaminación del agua y aumentar su calidad, mejorar notablemente el tratamiento de las aguas residuales y el aprovechamiento eficiente de los recursos hídricos y reducir las pérdidas de agua. Destacamos que para lograr esos propósitos se necesita asistencia y cooperación internacionales.

98 Véase Restrepo Gutiérrez, Elizabeth y Zárate Yepes, Carlos Alberto, "El mínimo vital de agua potable en la jurisprudencia de la Corte Constitucional colombiana”, Revista Opinión Jurídica, Universidad de Medellín, Medellín, Colombia, vol. 15, núm. 29, enero-junio, 2016, pp. 123-140. Señalan que la aplicación del mínimo vital de agua potable por medio de políticas públicas, acuerdos y decretos como ha sucedido en Colombia ha sido la forma de materializar el acceso a parte de la población a una cantidad de agua gratuita. Así, se han establecido varias cantidades como mínimo vital de agua potable que oscilan entre 0.6 y 2.5 metros cúbicos por persona 06 y 10 metros cúbicos por suscriptor. La aplicación de esta mínima cantidad de agua ha estado marcada por la focalización, y por requisitos que solo favorecen las leyes de mercado como es el acuerdo de pago para acceder al agua.

99 Véase UNESCO/OEA-Programa SARM Américas, Acuiferos Transfronterizos de las Américas, Estrategia regional para la evaluación y gestión de los sistemas acuíferos transfronterizos en las Américas, Montevideo, 2015, p. 140. Un programa de formación de recursos humanos en la temática hídrica, debe incorporar lineamientos claves para encarar una gestión del agua más comprensiva, que considere la interdependencia de los usos del recurso y los roles que juegan los distintos actores de la sociedad frente a los problemas relacionados con el agua. En particular, se debe abordar la evaluación y gestión de los acuíferos transfronterizos con el propósito de alentar el desarrollo de la visión inter y transdisciplinar que requiere la gestión sostenible del recurso hídrico, y así garantizar tanto el desarrollo socio-económico como la protección ambiental, sea este local, nacional o regional. 
embargo en otros países, no existe un seguimiento o gestión integral del recurso hídrico, ya que se encaminan atender la problemática de forma periódica y segmentada, sólo procuran la atención en un lapso de tiempo de tres a seis años en el caso de México el cual es el período establecido para el gobierno municipal, estatal y federal.

Finalmente, otro aspecto por resaltar del agua como bien vital, es la función que tiene para la sociedad productiva, debido a que representa un elemento clave del proceso. Los factores de ausencia y/o contaminación conllevan a pérdida de espacios vitales, suscitando elevados costos humanos y pérdida de la productividad social a nivel global $^{100}$. Se reitera el agua como bien vital para la vida humana, el papel de las transnacionales en conjunto con los gobiernos han convertido dicha concepción en una mercancía que se encuentra sujeta a la oferta y demanda del mercado, perdiendo su naturaleza de bien social por el simple hecho de pertenecer a la humanidad y deber estar al servicio de la misma así como de los demás ecosistemas ${ }^{101}$.

El sector privado en conjunto con el gobierno ha ido sectorizando y creando normas o leyes que les permita potencializar en el mercado este recurso natural, ejemplo de ello son las concesiones, la privatización del agua en forma embotellada ${ }^{102}$, fragmentando sin duda alguna el bien público lo que sitúa a las sociedades padecer del estrés hídrico.

\section{Bien común}

El agua es un recurso natural que da vida a todas las especies, sin embargo, tal parece que el ser humano decidió por cuenta propia que el agua le pertenece, permanece en estado de amnesia a tal grado que dentro de su propia especie ha ido delimitando a quien y cuanto del recurso hídrico debe proveer. Al respecto, en el ámbito común a través de su propio lenguaje considera restaurar un consenso de

\footnotetext{
100 Dowbor, Ladislaw. Op. cit. p. 177.

101 Agudelo C., Ruth Marina, "El agua, recurso estratégico del siglo XXI", Revista Facultad Nacional de Salud Pública, Universidad de Antioquia, Colombia, vol. 23, núm. 1, enero-junio de 2005, p. 101.

102 Véase Veraza, Jorge, Economía y política del agua, México, Itaca, 2007, p. 44. Menciona el caso de concesión que el $\mathrm{H}$. Ayuntamiento municipal de Cuautla y el gobierno federal de Luis Echeverría le otorgó a la compañía Coca-Cola para explotar los manantiales naturales ubicados bajo el predio en que se erige la empresa.
} 
equidad del agua, reconsiderando la supremacía de la ciudadanía en la conservación del mismo, frente a lo que conlleva la propiedad ${ }^{103}$.

La Carta Europea ${ }^{104}$ desde su redacción el 6 de mayo de 1968 en Estrasburgo establece a través de doce artículos que el agua es un tesoro, lo supone como el oro azul en el siglo XXI, enmarca el bien común cuyo valor debe ser reconocido por todos, teniendo la responsabilidad y deber de ahorrarla y usarla con cuidado requiriendo la cooperación de índole internacional.

$\mathrm{Su}$ carácter indispensable e insustituible hace del agua un bien común, una res publica ${ }^{105}$ como decían los romanos hace dos milenios de cuyo acceso no puede exceptuar a nadie sin razón o motivo alguno ${ }^{106}$.

La aplicación de garantizar a través del servicio público de calidad, la participación ciudadana en la gestión, cooperación y aplicabilidad del respeto al medio ambiente; se delimita a una transformación del concepto a partir de que no se estime solamente como mercancía en el que beneficie los intereses económicos de un sector único, ya que en caso contrario de realizarse se pierde esa naturaleza del bien común y por consecuencia el bien público ${ }^{107}$.

Motivo por el cual su valor como bien básico, escaso, necesario para la vida y la salud de las personas llega a grado tal que su no satisfacción puede ocasionar la destrucción de un ser humano. Por ello, ha sido considerado como patrimonio natural común de la humanidad, como prerrequisito para el cumplimiento de los

103 Barlow, Maude, El agua nuestro bien común, hacia una nueva narrativa del agua, Canadá, HEINRICH BÖLL STIFTUNG, 2009, p. 28.

104 El artículo 1 manifiesta que no hay vida sin agua; el artículo 2 considera el agua como un recurso no inagotable; artículo 3 refiere a la acción de contaminación como un acto que atenta a la vida humana; el artículo 4 describe la calidad del agua en su uso; el artículo 5 respecto al agua residual; el artículo 6 hace hincapié en mantener la cubierta vegetal; el artículo 7 señala que los recursos del agua deben ser inventariados; el artículo 8 puntualiza la planificación de las autoridades en la utilización de los recursos del agua; el artículo 9 refiere potencializar la investigación científica y formación de científicos; el artículo 10 la considera como bien común; el artículo 11 apunta respecto a la administración del agua en cuencas naturales y artículo 12 destaca que el agua no conoce de fronteras motivo por el cual debe concebirse de forma común bajo una perspectiva de cooperación internacional.

105 El término en latín de res publica, significa "cosa pública".

106 Petrella, Riccardo, El manifiesto del agua para el siglo XXI, Barcelona, ICARIA, 2004, p.1.

107 Torres Bernardino, Lorena, Sistema Lerma: una visión política en la gestión pública del agua, ¿solución estatal o federal? México, IAPEM, 2014, p. 51. 
derechos humanos e incluso, dada su necesidad básica, como un derecho fundamental ${ }^{108}$.

El criterio de patrimonio de la humanidad es reiterado por Jorge Veraza $^{109}$, quien plantea el recurso hídrico como un bien o valor de uso, un medio de vida externo y manipulado por los seres humanos de modo social o individual. Pero el agua también es patrimonio de la humanidad, precisamente porque es una premisa constitutiva y generativa de la vida que hoy en día presenta la forma externa de recurso natural no renovable y vital. Se retoma la idea del uso y aprovechamiento del agua como algo individual que conlleva al bien colectivo procurando la mejora y estabilidad de todos, el agua no tiene valor alguno adquiere ese valor al momento que tiene inserción en el mercado el cual se justifica con los Procedimientos Hidroútiles $(\mathrm{PHU})^{110}$ en el que a través de la intervención del trabajo del hombre adquiere un valor, el cual no debe ser exorbitante sólo debe ser el costo real del procedimiento que conlleva; respetando el derecho de acceso y uso como bien vital y común para la dignidad de la sociedad.

El reconocimiento de ese derecho parte de los derechos tradicionales de acceso y uso del mismo, se reconoce como un bien especial que se puede constituir en propiedad privada ${ }^{111}$ la cual esta legítimamente avalada, sin embargo, por el abuso de propiedad se reconsidera en el siglo XXI la visión del agua como bien natural público que debe ser gestionado para el bien común ${ }^{112}$.

Derivado de las situaciones de privatización, escasez, gestión y distribución del agua se otorga identidad a la catástrofe hídrica la cual es inminente ante una sociedad del riesgo como menciona

108 Tesis: II.1o.A.110, Semanario Judicial de la Federación y su Gaceta, Novena Época, t. XXII, noviembre de 2005, pp. 824.

109 Veraza, Jorge, Op. cit. p. 19.

110 Véase Veraza, Jorge, Economía y política del agua, México, Itaca, 2007, p. 15. Quien describe los procedimientos hidroútiles como los productos del trabajo humano y por ello contienen valor y pueden, bajo determinadas circunstancias sociales, devenir en mercancías.

111 En la Constitución Política de los Estados Unidos Mexicanos, en el Artículo 27 refiere que la propiedad de las tierras y aguas comprendidas dentro de los límites del territorio nacional, corresponde originariamente a la Nación, la cual ha tenido y tiene el derecho de transmitir el dominio de ellas a los particulares, constituyendo la propiedad privada...

112 Black Maggie, El secuestro del agua, la mala gestión de los recursos hídricos, España, Ed. Bigsa, 2005, p. 133. 
Ulrich Beck ${ }^{113}$ en donde sectores de la población están resintiendo la escasez del agua o simplemente han nacido en lugares donde la distribución de la misma es limitada siendo que la percepción del riesgo se encuentra vinculada a una necesidad de consumo.

Entonces ¿cómo garantizar el bien común para todos? de acuerdo a la OMS señala que la cantidad de agua por habitante es de cincuenta litros mínimo al día para cubrir las necesidades básicas de higiene y alimentos; pero en el desarrollo de estas dos décadas del siglo XXI, esa porción de agua que por derecho corresponde a cada ser humano es todo lo contrario, algunos no tienen y otros están sobreviviendo con cincuenta litros de agua por semana distribuido en todos los integrantes de la familia ${ }^{114}$.

Surge o se mantiene un caos ante las sociedades sin embargo, se debe rescatar y puntualizar la acción de trabajar en la conservación de este recurso aunque este amenazado por la agricultura, ganadería y cambio climático; existen mecanismos estratégicos que otorgan conservación del mismo, algunas ideas pueden ser gestionar el recurso por sectores o regiones de forma que tal acción se lleve de manera regulada y estricta; permitiendo la preservación de múltiples ecosistemas que de paso otorgan la sobrevivencia del ser humano en la tierra.

En términos simples "la vida demanda acceso al agua limpia; la acción de negación del derecho al agua obstaculiza el derecho a una vida digna" prepondera el mínimo vital, en el que el sujeto con sus relaciones sociales inmersas en las acciones o conductas delimitan sus propias necesidades básicas requeridas para el acceso a una vida digna ya sean de forma tangible/intangible basada en el sustento económico.

Ahora bien, tratando de comprender y asimilar un poco la concepción del mínimo vital para el bien común, es el propio sujeto quien va determinando, delimitando a través de su conducta y

113 Beck, Ulrich, La sociedad del riesgo, hacia una nueva modernidad, Barcelona, Paidós, 1998, p. 89-94.

114 Véase Expediente 49/2014, asunto: inconformidad, ponente ministro José Ramón Cossío Díaz, tema: abastecimiento de agua efectos de la sentencia: que las autoridades responsables cumplan de inmediato con el acceso al agua potable y saneamiento a que tiene derecho la quejosa. 
estándar de nuevas formas y estilos de vida las necesidades básicas que se requieren para poder acceder a una vida digna, es decir, para la satisfacción de acceso a bienes tangibles e intangibles en el que se requiere de un sustento económico, suscitando que en la demanda de ese bien haya un sobreconsumo y sobre explotación de los recursos con el objeto de atender y "satisfacer" la demanda.

Coexiste una sociedad que está siendo determinada por otra, lo que propicia que mientras unas se abastecen de ese "mínimo vital" para que sus necesidades estén cubiertas, existen otras sociedades que entran a un estado de pobreza al ser limitada de sus necesidades básicas que le proporcionan los recursos naturales, en los que tienen cubierta su "mínimo vital" y que el propio sistema económico desestabiliza al momento de lucrar y potencializar con los recursos y agotarlos; persiste entonces un estado de inexistencia del bien común o de estado de bienestar.

El principio organizador de la relación de la economía con la naturaleza, crea escenarios devastadores al permanecer la economía de mercado generando escasez de estabilidad orgánica ambiental, ecológica que con un costo más allá del económico, crea condiciones de pobreza y aunque el ser humano ya ha experimentado condiciones de indigencia surgen extremos de ese tipo de situación como lo es la pobreza extrema, es una relación de causa efecto de la acción humana con la naturaleza basada en el "desarrollo" de la economía de mercado conducente a la reducción del espacio de la naturaleza y el espacio de la gente ${ }^{115}$.

Barlow Maude ${ }^{116}$ refiere que bajo un esquema de aceptación del agua en un sistema de mercado no se puede catalogar como bien social, político o común ya que las personas son vistas como usuarios o clientes, no como personas con derechos a un recurso colectivo.

En esta visión del mundo es importante resaltar que el agua es patrimonio de todos por lo tanto su consideración como bien común se debe reconocer bajo las normas y leyes eficaces que el propio

115 W. Sachs (editor)., Diccionario del desarrollo, una guía del conocimiento como poder, Perú, PRATEC, 1996, pp. 333-334.

116 Barlow, Maude, El agua nuestra bien común, hacia una nueva narrativa del agua, Canadá, HEINRICH BÖLL STIFTUNG, 2009, p. 27. 
sujeto ha creado, resguardando así un medio que sea el proveedor de un beneficio común que realmente garantice el acceso, uso, gestión y distribución del agua como bien público.

Aunque dicha labor puede mantenerse en incertidumbre debido al crecimiento ilimitado de los mercados que no precisamente hacen posible la sustentabilidad, hallándose en una incongruencia de demanda y costo, la demanda referida al mercado de acuerdo a objetos estimados con un valor económico y el costo referido a la naturaleza, ya que no hay un retorno a corto plazo de la producción de los recursos naturales que llegue a satisfacer en tiempo las demandas del mercado a través de la producción; sin embargo tal parece que el anunciado "bien común" está haciendo eco en el siglo XXI, teniendo un límite impuesto por la propia naturaleza; manifestando los efectos de procesos del cambio climático.

\section{Derecho humano}

En el marco jurídico internacional y universal en materia de medio ambiente, los derechos humanos tienen reconocimiento a partir de la tercera generación ${ }^{117}$ (violaciones a los derechos colectivos) en los cuales se enmarcan la violación del derecho al desarrollo; derecho a disfrutar de un medio ambiente sano y ecológicamente equilibrado; daño ecológico; derecho a disfrutar del patrimonio común de la humanidad; derecho a la paz y derecho a ser diferente; considerándose de carácter colectivo y difuso.

A partir de la incorporación y reconocimiento en la Declaración Universal de los Derechos Humanos en el artículo 25.1 que a la letra dice "Toda persona tiene derecho a un nivel de vida adecuado que le asegure, así como a su familia, la salud y el bienestar..." si bien no se expresa tácitamente el reconocimiento al derecho a un medio ambiente sano, se da por hecho que el desarrollo del derecho

117 La primera generación surge con la Revolución Francesa, constituida por derechos civiles y políticos, siglo XVIII y XIX. La segunda generación surge con la Revolución Industrial, conformada por derechos colectivos económicos, sociales y culturales, siglo XIX y XX. La tercera generación surge con las necesidades constituidas por los derechos de los pueblos o de solidaridad siglo XX y XXI (paz, desarrollo y medio ambiente), engloban los dos derechos civiles, políticos, económicos, sociales y culturales, aunándose los de cooperación entre los pueblos. 
de una vida adecuada con salud y bienestar se debe garantizar con un entorno natural, considerando la satisfacción de las necesidades básicas, al mismo tiempo que se prevean los recursos para las generaciones futuras.

El antecedente de reconocimiento al derecho al agua, se puede expresar que, a partir del año de 1977 en Mar de Plata Argentina en la Conferencia del Agua de las Naciones Unidas, en donde se proclama el derecho al agua en el que todas las personas tienen derecho a tener acceso a agua potable en cantidad y calidad iguales a sus necesidades básicas.

Naciones Unidas ${ }^{118}$ a través de la Resolución aprobada por la Asamblea General el 28 de julio de 2010 64/292, reconoce que el derecho al agua potable y el saneamiento es un derecho humano esencial para el pleno disfrute de la vida y de todos los derechos humanos.

Sin embargo, retoma mayor relevancia con la Declaración Universal de Derechos Humanos Emergentes ${ }^{119}$ conocidos como los derechos del siglo XXI; en materia de medio ambiente se considera de importancia e incluso como vital, garantizar el agua mediante las condiciones necesarias para la supervivencia del ser humano.

Se comprende que este derecho es para todas las personas y que por lo tanto se tiene el derecho a disponerla de forma suficiente refiriéndose al hecho de abastecerla continuamente, salubre obedeciendo al hecho de estar libre de microorganismo, químicos y material tóxico-peligroso que puedan considerarse de amenaza para la salud de la especie humana, aceptable refiriendo que el recurso hídrico debe presentar un color, olor y sabor aceptable, asequible en cuanto a que los servicios e instalaciones de acceso deben ser factible y posibles para el uso personal y doméstico ${ }^{120}$.

Se destaca el derecho de saneamiento como el derecho de acceso a este servicio adecuado y seguro con el objeto de proteger

118 Resolución A/RES/64/292, Asamblea General de las Naciones Unidas, Comité de Derechos, Julio de 2010.

119 Tiene su origen desde el año 2004 en Barcelona, España, es aprobado en Monterrey, México en el año 2007. Su objeto es reivindicar hacia una sociedad justa y solidaria de acuerdo a las nuevas necesidades en medio ambiente y biotecnología.

120 Comité ESCR, Observación General no. 15 el Derecho al Agua, nota 30, párrafo 3. 
la salud pública, así como el medio ambiente ${ }^{121}$. Se considera los nexos la interdependencia e indivisibilidad con otros derechos humanos de relevancia para la especie humana, como es el derecho a la salud, alimentación, vivienda y principalmente el derecho a la vida. Es entonces que procede en materia de cantidad y calidad a principios fundamentales de justicia social ${ }^{122}$ concerniente a igualdad de la ciudadanía; el mínimo social; el mínimo vital e igualdad de oportunidades y distribución justa.

En este aspecto el derecho humano al agua, recapitula acciones concretas y con características específicas del recurso hídrico para el consumo del mismo por los seres humanos, conlleva medidas catalogadas de "calidad" en el agua, por lo que si en algún momento esas características no estuviera garantizadas el ser humano no podría hacer uso de ella, afectando, vulnerando y/o violando otros derechos de forma directa e indirecta, que a mediano plazo hacen manifiestos situaciones de disputas por el acceso al agua, situándose así una discrepancia entre lo que enmarca el Estado de Derecho, la representación de cualquiera de los poderes legítimos del mismo y la propia sociedad, es una brecha cada vez más grande entre lo que se pretende y quiere a lo que realmente es.

Un ejemplo de lo anterior en México, es el caso de inconformidad $49 / 2014^{123}$ en la exposición de motivos realizada por el ponente

121 ONU, Directrices para la realización del derecho al agua y saneamiento, Adoptadas por la subcomisión de promoción y protección de los derechos humanos, 2005.

122 PNUD, Informe sobre Desarrollo Humano 2006, Más allá de la escasez: Poder y la crisis mundial del agua, Nueva York, 2006.

123 El miércoles 26 de noviembre, la Suprema Corte de Justicia de la Nación (SCJN) resolvió la inconformidad 49/2014 a nombre de Lidia Velázquez Reynoso reconociendo la violación del derecho humano al agua de acuerdo a los estándares mínimos establecidos en los Tratados y por los Organismos internacionales correspondientes. Expediente 49/2014, asunto: inconformidad, ponente Ministro José Ramón Cossío Díaz, tema: abastecimiento de agua efectos de la sentencia: que las autoridades responsables cumplan de inmediato con el acceso al agua potable y saneamiento a que tiene derecho la aquí quejosa, bajo los siguientes lineamientos: a).- deberán tomarse las medidas necesarias para que el proyecto o programa aludido en la quinta etapa descrita en el oficio reclamado, de inmediato se revise para su autorización por parte de la entidad correspondiente y, en su caso, se concluya a la brevedad. b).- deberán realizarse los trámites respectivos, a fin de que el domicilio de la aquí quejosa, tenga acceso, disposición y saneamiento de agua para consumo personal y doméstico en forma suficiente, salubre, aceptable y asequible, para lo cual necesariamente deberá ser incluido en los proyectos o programas que sobre el particular se realicen; sin que lo anterior implique que 
ministro José Ramón Cossío Díaz, del cual señala que este derecho se enmarca dentro del derecho social por antonomasia, se trata de un derecho prestacional en la medida de que principalmente implica una serie de obligaciones positivas o de hacer a cargo de los poderes públicos. El derecho humano al agua se considera de primera generación e inherente a la dignidad humana, dado que el abastecimiento de agua salubre es necesario para evitar la muerte por deshidratación, para reducir el riesgo de las enfermedades relacionadas con el agua y para satisfacer las necesidades de consumo y cocina, así como las necesidades de higiene personal y doméstica.

Derivado de lo anterior es preciso mencionar el 10 de junio de 2011, con la publicación del cambio de la denominación en la Carta Magna siendo ahora denominado "De los derechos humanos y sus garantías".

En el año 2012 se publica en el Diario Oficial de la Federación la adición al artículo $4^{\circ}$ constitucional.

Este derecho humano se encuentra reconocido por fuentes internacionales, como la Observación General No. $15^{124}$ del Comité de Derechos Económicos, Sociales y Culturales de la Organización de las Naciones Unidas que es el órgano facultado para interpretar y establecer los alcances del Pacto Internacional de Derechos Económicos, Sociales y Culturales suscrito y ratificado por México y publicado en el Diario Oficial de la Federación el 12 de mayo de 1981, la cual constituye una interpretación más amplia y favorable del citado derecho a la luz de este último instrumento internacional y resulta obligatoria para nuestro país en términos del artículo $1^{\circ}$

\footnotetext{
la quejosa deba quedar excluida de las obligaciones que todo usuario de agua potable tiene, conforme a las leyes establecidas para tal efecto; y c).- por tratarse de un derecho humano de primera generación, por las razones apuntadas en la presente ejecutoria, en tanto se da cumplimiento con lo anterior, la responsable deberá abastecer a la quejosa del vital líquido en mención, por medio de pipas. ATF/GAGG, Órgano jurisdiccional de origen y datos del expediente respectivo: Juzgado cuarto de distrito en el Estado de Morelos (exp. origen: j.a. 1922/2010) segundo tribunal colegiado en materia de trabajo del decimoctavo circuito (exp. origen: a.r. 381/2011 e inconformidad 7/2014). Órgano de radiación: primera sala, fecha de resolución: sesionado el 26/11/2014. Punto resolutivo: 26/11/2014 1. Es fundada. 2 . Se revoca el acuerdo recurrido. 3. Devuélvanse los autos del juicio de amparo al juez de distrito del conocimiento, para los efectos precisados en la resolución.

124 Observación General No. 15, El derecho al agua, Comité de Naciones Unidas de Derechos Económicos, Sociales y Culturales, noviembre de 2002.
} 
segundo párrafo, constitucional ${ }^{125}$ precisa que el derecho al agua es el derecho de todas las personas a disponer de agua suficiente, salubre, aceptable, accesible y asequible para uso personal y doméstico, el cual es motivado por la preocupación de los aproximadamente ochocientos ochenta y cuatro millones de personas carentes de acceso al agua potable y más de dos mil seiscientos millones de personas que no tienen acceso a saneamiento básico.

José Ramón Cossío ${ }^{126}$ expresa que el agua como derecho es un recurso regulado de diversas formas en la Constitución y para su comprensión resulta un modelo complejo desde su entendimiento hasta su operación, agravado en su funcionamiento por el imperativo de poder satisfacer esa "necesidad humana básica" lo que lleva a reflexionar hacia la viabilidad de enmarcar esa satisfacción como un derecho humano, considerando que no sólo representa un tema viejo, sino que además se necesita una nueva forma de resiliencia a dicho término y aplicabilidad.

Así la exigibilidad y cumplimiento de acuerdo a las nuevas necesidades y demandas de atención a ese derecho en el cual se debe contemplar una visión interdisciplinaria ${ }^{127}$. Nos acerca entonces a poder comprender realidades sociales que determinen una interpretación real del hecho social a partir de una conjunción de los actores involucrados promoviendo una reconversión de identidad jurídica a través de su contenido concreto, sentido y alcance.

Nos atañe entonces resaltar el "principio pro persona", conforme al cual la interpretación jurídica siempre debe buscar el mayor beneficio para el hombre, el derecho humano al agua, es aquel a disponer de la suficiente, salubre, aceptable, accesible y asequible para el uso personal y doméstico; un abastecimiento adecuado es necesario para evitar la muerte, y para satisfacer las necesidades de consumo, cocina e higiene personal y doméstica, lo que se logra con

125 Tesis: VI.3o.A.1 CS (10a.), Semanario Judicial de la Federación y su Gaceta, Décima Época, t. II, julio de 2015, p. 1721.

126 Cossío Díaz, José Ramón, Derecho y ciencia, Tirant lo Blanch, México, 2015, pp. 171-173.

127 Silva Hernández, Francisca, "Mecanismos Alternativos de Solución de Controversias como vía colaborativa en la responsabilidad ambiental" en Derechos Humanos, un escenario comparativo entre los sistemas universal, regional y nacional, México, Flores editores, 2016, pp. 390-392. 
el abastecimiento de agua que de cada persona debe ser continuo y suficiente para los usos personales y domésticos; la cantidad disponible para cada persona debería corresponder a las directrices de la OMS por lo que el agua, las instalaciones y los servicios deben ser accesibles para todos, sin discriminación alguna dentro de la jurisdicción del Estado Parte.

Por ello, si el agua y los servicios e instalaciones deben ser accesibles a todos de hecho y de derecho, incluso a los sectores más vulnerables y marginados de la población, sin discriminación alguna, a fin de garantizar la tutela de ese derecho humano, los Estados Partes deben adoptar medidas para eliminar la discriminación cuando se prive a las personas de los medios o derechos necesarios para ejercer su derecho al agua; además, deben velar porque la asignación de los recursos de agua y las inversiones, faciliten su acceso a todos los miembros de la sociedad; pues las transformaciones no deben ser en beneficio de una fracción privilegiada de la población, sino invertirse en servicios e instalaciones que redunden a favor de un sector más amplio, conforme a una interpretación no restrictiva, atendiendo al principio pro homine, que permite acudir a una interpretación del derecho al agua acorde con los principios sustentados en la Constitución Federal y en los derechos humanos contenidos en los instrumentos internacionales referidos, a partir de una interpretación que favorezca en todo tiempo a las personas la protección más amplia ${ }^{128}$.

Resulta complejo poder dar cabal cumplimiento a todos los ciudadanos al acceso de este derecho humano ya que como se ha mencionado es un recurso limitado y que hoy día se incrementan los territorios de escasez del vital líquido, sin embargo, como sociedad se debe ser consciente del uso y gestión, lamentablemente muchas veces no se llega a concebir como una crisis hasta que se padece del acceso.

Aunque el reconocimiento del derecho humano al agua es reciente de hace algunas décadas, constituye un parte aguas del interés que se tiene en este recurso. Su importancia de reconocimiento

128 Tesis I.9Po.69 P (10ª.), Semanario Judicial de la Federación y su Gaceta, Décima Época, t. IV, noviembre de 2014, p. 2928. 
desde los tratados internacionales ${ }^{129}$ en cuanto a la exigibilidad del derecho del ciudadano debe ser vinculante, exigible e invocado en los ordenamientos jurídicos nacionales a través de los mecanismos que el sistema u ordenamiento jurídico ofrecen, existen formas de invocarlos como el caso de la inconformidad 49/2014 antes citada.

Finalmente, cabe asumir que el derecho humano al agua, conlleva otros aspectos que resultan controversiales como el derecho de propiedad, alimentación, salud, vivienda, hasta la propia vida; resulta ser algo que nace a la luz del marco de la crisis de necesidades básicas y vitales del ser humano, pero que a la vez se haya en proceso de poder integrar de forma simétrica o proporcionada el derecho humano al agua con el otro $\mathrm{u}$ otros derechos humanos vinculantes, resulta un proceso de avance a una situación paradigmática y en constante cambio que no es más que el propio sujeto social quien determinará el proceso del mismo en la confrontación del espíritu humano y el sistema económico predominante y determinante de las sociedades.

\section{Seguridad mundial y nacional}

El cambio climático tiene una serie de consecuencias en todos los contextos de la humanidad, hoy día el mundo se rige bajo parámetros de la sostenibilidad que garantice mejor calidad de vida, sin embargo, se considera que estamos en una etapa de reestructuración de nuevos procesos dinámicos y complejos en el que la integración absoluta de la conducta del ser y deber ser tiene consecuencia directa e indirecta entre todos los sujetos y el medio.

Preside un conjunto de acciones humanas que inciden sobre el sistema ecológico natural y el conjunto de efectos ecológicos generados en la naturaleza exteriorizados en el sistema social ${ }^{130}$.

No es simplemente ver la realidad fragmentada sino comprender que el hombre es parte de un medio en el que no es ajeno a él; el

129 Salmón, Elizabeth, "Los (tímidos) aportes del derecho internacional a la construcción del derecho humano al agua”, p. 85. en Hoogesteger, Jaime y Urteaga, Patricia, Agua e inequidad: discursos, políticas y medios de vida en la región andina, Instituto de Estudios Peruanos, Lima, 2013.

130 Gallopín, Gilberto, Ecología y ambiente, los problemas del conocimiento y la perspectiva ambiental del desarrollo, México, siglo XXI, 1986, p. 161. 
sujeto es un ser evolucionista que como todo ser vivo tiene un ciclo de vida dentro de un medio, en este caso el ser vivo, como sujeto social, como ciudadano, como persona, debe considerar que es él quien depende del medio y no el medio de él.

La seguridad del agua se define como:

La capacidad de una población para salvaguardar el acceso sostenible a cantidades adecuadas de agua de calidad aceptable para el sustento, el bienestar humano y el desarrollo socio-económico, para garantizar la protección contra la contaminación transmitida por el agua y los desastres relacionados con el agua, y para la conservación de los ecosistemas en un clima de paz y estabilidad política $^{131}$.

$\mathrm{Al}$ respecto, en el caso del agua vale la pena considerarlo como elemento que garantiza la supervivencia y el desarrollo de la vida humana, animal y vegetal, de igual forma los procesos económicos y medio ambientales ${ }^{132}$ por ello, el acceso y gestión de la misma se considera para la supervivencia de la especie humana, fortalece el acceso a otros derechos, lo que lleva a plantearlo con carácter de seguridad nacional y mundial por motivos de haber desencadenado una serie de fenómenos sociales que acrecientan la crisis económica y política entre países y naciones, tales como la pobreza, migración, desplazamientos, deshidratación, nuevas enfermedades, epidemias, virus, entre otros, los cuales aceleran los indicadores de sostenibilidad o insostenibilidad para el Estado ${ }^{133}$ resultando con costos elevados de atención.

La atención de seguridad mundial y nacional ${ }^{134}$ respecto al agua acarrea consideraciones como la desaparición de ríos durante los próximos cincuenta años como el caso del río Níger en África, el Po en Italia, el Colorado en Estados Unidos, el Yang-tsé en China. En el año 2007 el río Amazonas se

131 ONU-Water Analytical Brief on Water Security and the Global Water Agenda, 2013.

132 Black Maggie, El secuestro del agua, la mala gestión de los recursos hídricos, España, Bigsa, 2005, p. 11.

133 Véase García, Aniza, El derecho humano al agua, México, Ed. Trotta, 2008, p. 194. Refiere que como obligado al derecho internacional e interno en materia de derechos fundamentales es el Estado, se han establecido estándares internacionales que obligan a que los Estados adopten las medidas necesarias para cubrir, por lo menos, el mínimo de las necesidades más elementales.

134 Petrella, Riccardo, El manifiesto del agua para el siglo XXI, Barcelona, ICARIA, 2004 p. 3. 
secó en ciertos lugares. Las causas de la degradación del recurso hídrico son motivadas por cuestiones de extracción excesiva, drenajes, mayor cantidad de presas y contaminación lo cuales en su mayoría se derivan de las explotaciones industriales, energéticas y mineras situadas a lo largo de los ríos.

La UNESCO, considera relevante el recurso hídrico, tanto así que ha establecido el Programa Hidrológico Internacional (PHI) ${ }^{135}$ el cual versa en los aspectos de desarrollado con base a la escasez y calidad del agua.

El PHI "Seguridad hídrica: respuestas a los desafíos locales, regionales y mundiales" 136 concede la seguridad a partir de los siguientes desafíos: desastres relacionados con el agua y cambios hidrológicos; el agua subterránea en un medio ambiente cambiante; la escasez y calidad del agua; agua y asentamientos humanos; eco hidrología; educación y cultura del agua. Este último como pieza clave para establecer la seguridad hídrica a partir de los factores de crecimiento poblacional, industrialización y urbanización la cual acrecienta la vulnerabilidad ecológica y humana.

Para el Banco Mundial ${ }^{137}$ la seguridad hídrica continúa siendo de los riesgos mundiales, la población y el crecimiento económico ejercen una presión sin precedentes sobre este recurso plantea que, para lograr la seguridad hídrica universal mediante dos objetivos establecidos, el primero refiere a eliminar la pobreza extrema a más tardar a fines de 2030 y el segundo impulsar la prosperidad.

La inseguridad hídrica podría multiplicar el riesgo de conflictos, el alza abrupta del precio de los alimentos suscitado por las sequías podría avivar conflictos latentes y provocar migraciones. Cuando el crecimiento económico se ve afectado por las lluvias se afirma, los

135 Programa Hidrológico Internacional, $22^{\mathrm{a}}$ reunión del Consejo Intergubernamental, París, 13-17 de junio de 2016; IHP/IC-XXII/1, El Programa Hidrológico Internacional (PHI) es el único programa intergubernamental del sistema de las Naciones Unidas dedicado a la investigación sobre el agua, la gestión de los recursos hídricos y la educación y la creación de capacidades. El programa, ajustado a las necesidades de los Estados Miembros, se ejecuta en fases de seis años, lo que permite adaptarlo a un mundo en rápida evolución.

136 UNESCO, IHP/2012/IHP-VIII/1, Plan Estratégico PHI-VIII 2014-2021, pp. 19-45.

137 Véase The Global Risks Report 2016, 11th edition is published by the World Economic Forum within the framework of the Global Competitiveness and Risks Team. 
episodios de sequías e inundaciones generan olas de migraciones y brotes de violencia dentro de los países ${ }^{138}$.

En el 2012, la SCJN advierte que a partir de la concepción del derecho humano y concepción de seguridad nacional al derecho al agua potable, se convierte fundamental e indispensable para la realización, goce y disfrute de los demás derechos humanos, cuya preservación en cantidad, calidad y sustentabilidad es tarea fundamental tanto del Estado como de la sociedad, por cuanto a que tal derecho está basado en las premisas de un acceso al bienestar de toda la población, sustentado por los principios de igualdad y no discriminación, independientemente de las circunstancias sociales, de género, políticas, económicas o culturales propias de la comunidad en la que se opera.

Es así que señala al Estado como la figura que garantizará el derecho al agua de forma segura, aceptable, accesible y asequible tanto para uso personal como doméstico, erigiéndose como un beneficio colectivo que debe basarse en criterios de solidaridad, cooperación mutua, equidad y en condiciones dignas, por lo que se ha proclamado de prioridad y de seguridad nacional la preferencia del uso doméstico y público urbano en relación con cualquier otro uso, razones que excluyen la posibilidad de que pueda ser concebido atendiendo a intereses particulares o de grupos minoritarios, pues de ser así, imperaría un régimen de aprovechamiento del agua sin visión humana y social, con lo cual se atentaría contra la dignidad humana ${ }^{139}$. Esta tesis alude criterios que considera el beneficio colectivo de forma general prevaleciendo la dignidad humana, sin embargo queda muy ambiguo la garantía del mismo, apertura a activar la participación ciudadana concibiendo la premisa de acceso al bienestar de la población.

El Plan Nacional de Desarrollo (PND) 2019-2020 ${ }^{140}$ supone la política de Seguridad Nacional como un cambio de paradigma de

138 Véase High and Dry: Climate Change, Water and the Economy. World Bank Group, Washington, DC, 2016.

139 Tesis: XI.1o.A.T.1 K (10ª), Semanario Judicial de la Federación y su Gaceta, Décima Época, t. 3, septiembre de 2012, p. 1502.

140 Plan Nacional de Desarrollo 2019-2024, Diario Oficial de la Federación, Secretaría de Gobernación, Andrés Manuel López Obrador, México, 2019. La Estrategia Nacional de 
seguridad basada en una política de paz y seguridad integral en la que reconoce la función esencial del Estado y derecho fundamental de los ciudadanos, invoca e interpreta los tratados internacionales en los que está suscrito México, salvaguardando toda protección hacia el Estado mexicano de forma democrática, soberana e independiente.

Como aspecto a resaltar de los objetivos vinculado al tema de interés abordado, es el objetivo del pleno respeto a los derechos humanos, planteando la búsqueda de reformas que permitan dotar de obligatoriedad legal. El objetivo 4 regeneración ética de las instituciones y de la sociedad, parte de señalar dos tipos de regeneración la ética y moral. La primera enfatizada a la intención ejemplificante de un ejercicio de gobierno austero, honesto, transparente, incluyente, respetuoso de las libertades, apegado a derecho, sensible a las necesidades de los más débiles y vulnerables y pendiente en todo momento del interés superior. Y la segunda como el medio y propósito de la administración de gobierno que se dirija a una democracia participativa.

Esta consideración da pauta a una serie de criterios que fortalecen la idea de la relación horizontal del Estado y el ciudadano a través de una soberanía asumiendo los tratados internacionales de forma participativa, incluyente mediante la democracia, fortaleciendo los ejes de desarrollo económico, social y político, sin embargo, el aspecto ambiental no es considerado dentro de los ejes de desarrollo principales, solo se señala como el medio primario que se utilicen para ejecutar las acciones de alcanzar los ejes de desarrollo productivo.

Acciones que consideran en el PDN 2019-2024 al recurso hídrico son las siguientes:

Seguridad Pública, aprobada por el Senado de la República, establece los siguientes objetivos: 1. Erradicar la corrupción y reactivar la procuración de justicia; 2. Garantizar empleo, educación, salud y bienestar; 3 . Pleno respeto a los derechos humanos; 4 . Regeneración ética de las instituciones y de la sociedad; 5. Reformular el combate a las drogas; 6. Emprender la construcción de la paz; 7. Recuperación y dignificación de las cárceles; 8 . Articular la seguridad nacional, la seguridad pública y la paz; 9. Repensar la seguridad nacional y reorientar a las Fuerzas Armadas; 10. Establecer la Guardia Nacional; 11. Coordinaciones nacionales, estatales y regional; 12. Estrategias específicas: nuevo modelo policial, prevención del delito, desarrollo alternativo, prevención especial de la violencia y el delito. 
- En las Universidades para el Bienestar Benito Juárez García. Proyecto planteado en infraestructura con 100 planteles en 31 entidades $^{141}$. Se ofertan las carreras de Ingenierías Ambiental, Agroforestal, en Desarrollo Regional Sustentable, en Administración de la Industria Energética y en Procesos Petroleros, en Energías Renovables; Gestión Integrada del Agua.

- En el proyecto regional Programa para el Desarrollo del Istmo de Tehuantepec ${ }^{142}$. Se plantea que a lo largo del recorrido entre ambos océanos se crearán zonas libres para atraer inversiones del sector privado, las cuales se dotarán de infraestructura y se garantizará el abasto de energía, agua, conectividad digital y otros insumos básicos para cubrir las necesidades de las empresas y de la población trabajadora.

141 Con base a PND 2019-2024. Para la instalación de los planteles se dio preferencia a zonas de alta densidad poblacional en las que haya nula oferta de estudios universitarios y con alto grado de rezago social, marginación y violencia. Las escuelas universitarias se distribuyen en Oaxaca (11 planteles), Ciudad de México (10), Veracruz (8), Chiapas y Guanajuato (6). Las otras entidades tienen entre 2 y 5 escuelas. En conjunto, las Universidades para el Bienestar ofrecen 32 mil plazas para estudiantes, los cuales recibirán una beca de 2 mil 400 pesos mensuales. Los edificios permanentes en los que operarán las Universidades para el Bienestar serán construidos con el concurso del trabajo comunitario y de trabajadores locales, en terrenos donados o entregados en comodato por campesinos, municipios o comisariados ejidales. Las carreras que se ofrecen son Ingenierías Civil, Industrial, Forestal, Agroalimentaria, Ambiental, Agroforestal, Electromecánica, Agronomía, en Minas, Piscícola, en Acuacultura, en Desarrollo Regional Sustentable, Química de la Industria Petrolera, en Administración de la Industria Energética y en Procesos Petroleros, en Energías Renovables; Medicina Integral y Salud Comunitaria; Enfermería y Obstetricia; Medicina Veterinaria y Zootecnia; Contabilidad y Administración Pública; Derecho; Patrimonio Histórico e Industria de Viajes; Gestión Integrada del Agua; Normal de Educación Básica; Estudios Sociales; Patrimonio Histórico y Biocultural; Educación Física; Administración Municipal y Políticas Públicas; Música y Laudería y Normales Rural e Intercultural Bilingüe.

142 Su objetivo es impulsar el crecimiento de la economía regional con pleno respeto a la historia, la cultura y las tradiciones del Istmo oaxaqueño y veracruzano. Su eje será el Corredor Multimodal Interoceánico, que aprovechará la posición del Istmo para competir en los mercados mundiales de movilización de mercancías, a través del uso combinado de diversos medios de transporte. En este marco se modernizará el ferrocarril del Istmo de Tehuantepec, los puertos de Coatzacoalcos, Veracruz, y Salina Cruz, Oaxaca, para que puedan ofrecer servicios de carga, transporte, almacenaje, embalaje y servicios logísticos diversos; se fortalecerá la infraestructura carretera y de caminos rurales y la red aeroportuaria y se construirá un gasoducto para abastecer a empresas y consumidores domésticos. 
- En el Programa Producción para el Bienestar ${ }^{143}$ canaliza apoyos productivos a las siembras e impulsa productos con prácticas agroecológicas, sustentables, conservación del suelo, el agua y agro diversidad.

- El Programa de apoyo a cafetaleros y cañeros del país ${ }^{144}$ se orientan a impulsar la renovación de cafetales, el uso de mejores materiales genéticos, la implementación de prácticas de producción sustentables, a la agregación de valor y diferenciación de sus productos y a la conservación y mejor uso del suelo y del agua y a la conservación de la biodiversidad.

- En el apartado de Epílogo: visión de 2024, establece que para el año 2021, se habrá garantizado la preservación integral de la flora y de la fauna, se habrá reforestado buena parte del territorio nacional y ríos, arroyos y lagunas estarán recuperados y saneados; el tratamiento de aguas negras y el manejo adecuado de los desechos serán prácticas generalizadas en el territorio nacional y se habrá expandido en la sociedad la conciencia ambiental y la convicción del cuidado del entorno.

Estos planteamientos establecidos en el PND 2019-2024, suponen temas del agua alineados y derivados de otras acciones o programas. En tema ambiental se debe fortalecer líneas estratégicas que aborden de forma especifica el tema del agua y todas aquellas disputas derivadas de la misma.

La Ley de Aguas Nacionales (LAN) ${ }^{145}$ considera el agua como bien de dominio público federal, vital, vulnerable y finito, con valor social, económico y ambiental, cuya preservación en cantidad y calidad y

143 Orientado a los productores de pequeña y mediana escala, beneficiará a unos 2.8 millones de pequeños y medianos productores (hasta 20 hectáreas), que conforman el 85 por ciento de las unidades productivas del país, con prioridad para 657 mil pequeños productores indígenas.

144 Este programa sustentado en el PND 2019-2024, dos programas emergentes orientados a apoyar a los pequeños productores de café y de caña de azúcar, mediante el cual estaremos beneficiando 420 mil productores. Doscientos cincuenta mil pequeños productores de café y 170 mil de caña de azúcar.

145 Título tercero, Política y Programación Hídricas, capítulo único, sección primera, Política Hídrica Nacional, artículo 14 BIS 5, inciso I. 
sustentabilidad es tarea fundamental del Estado y la sociedad, así como prioridad y asunto de seguridad nacional.

El adjetivo de dominio, reconfigura una descripción vulnerable con valor social, enunciándose hacia un valor netamente económico, se enfoca al dominio exclusivo del Estado mediante la federación; en el cual se puede señalar que la misma ley establece la integración de las comisiones que determinan el uso y gestión del vital líquido, no aplicándose una consulta previa o participación ciudadana cuando se requiere y situando a los propios funcionarios en la decisión que atañe a problemas sociales o decisiones "para el bienestar común", aunado a eso existe una verticalidad y jerarquización en la toma de decisiones, en su mayoría el representante del poder ejecutivo es quien valora y decide las disposiciones de uso y aprovechamiento del agua, es decir, el "bien común" es entonces el juicio de una sola persona en turno quien determina el presente y futuro de millones de vidas de generaciones presente y futuras.

La Ley General de Desarrollo Social ${ }^{146}$ establece como prioridad y de interés público, todos aquellos programas y obras de infraestructura para agua potable, drenaje, electrificación, caminos y otras vías de comunicación, saneamiento ambiental y equipamiento urbano.

Luis Aboites ${ }^{147}$ señala que a mediados del siglo XX se tenía una visión del uso del agua como una fuente de progreso para el desarrollo, sin embargo a finales de ese mismo siglo el gobierno empieza a reconsiderar esa posición ahora bajo un esquema de optimización debido a la escasez y contaminación; esto es derivado de las acciones y consecuencias de los procesos agrícolas y la industria; aunado a nivel mundial empiezan a surgir una serie de acontecimientos que llaman al cuidado de los recursos naturales. Es entonces que en México del agua que había que dominar y controlar se pasó al agua que había que cuidar.

146 Ley General de Desarrollo Social, Ley publicada en el Diario Oficial de la Federación el 20 de enero de 2004, artículo 19, fracción IX, últimas reformas publicadas DOF 01-06-2016. 147 Aboites Aguilar, Luis, "De bastión a amenaza. Agua, políticas públicas y cambio institucional en México, 1974-2001”, en Graizbord, Boris y Arroyo Alejandre, Jesús (coords.), El futuro del agua en México, México, COLMEX, PROFMEX, 2011, p. 89. 


\section{Enfoque sociohidrológico}

Es catalogado como un paradigma multidisciplinario en el siglo XXI para la ciencia hídrica. Loucks ${ }^{148}$ socializa los aspectos de planeación y gestión del recurso hídrico en cuatro criterios sustanciales:

1. Recursos naturales que involucran las aguas superficiales y subterráneas.

2. La infraestructura hidráulica asociada a recursos naturales: canales, presas, pozos y plantas de bombeo, entre otros.

3. Componente socioeconómico vinculado con el uso consuntivo y su atribución a las actividades humanas.

4. Sistema institucional de administración, legislación y regulación del agua.

Para Loucks la integración de estos cuatro aspectos detonan el proceso eficaz transversal de la planeación y gestión del agua como a continuación se muestra.

\section{Gráfico 4. Planeación y gestión de los recursos hídricos}

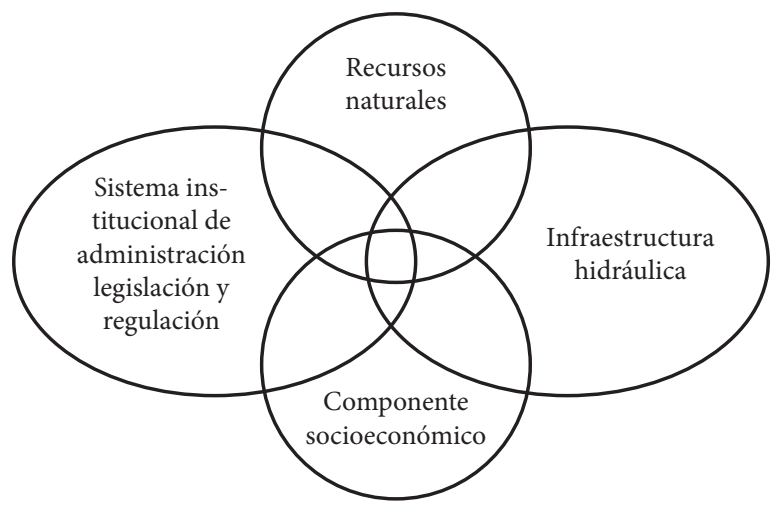

Fuente: Construido con base a Loucks, D. P., E. Van Beek, J. R. Stedinger, J. P. Dijkman, and M. T. Villars, Water Resources Systems Planning and Management: An Introduction to Methods, Models and Applications, Paris, UNESCO, 2005.

148 Loucks, D. P., E. Van Beek, J. R. Stedinger, J. P. Dijkman, and M. T. Villars, Water Resources Systems Planning and Management: An Introduction to Methods, Models and Applications, Paris, UNESCO, 2005. 
La interacción entre el ser humano y el agua ha evolucionado en diversas sociedades, respondiendo a los intereses, necesidades y objetivos que la sociedad valore o considere en un tiempo y espacio determinado ejecutando acciones emergentes que cada vez deben ser comprensibles desde un enfoque sociohidrológico, entendiendo a este como una articulación multidisciplinaria.

Sivapalan y Blöschl ${ }^{149}$ han propuesto una clasificación sociohidrológica en función de la capacidad de una sociedad de cambiar sus valores o preferencias con respecto al uso y gestión de los recursos hídricos en el tiempo, así como de las diferencias espaciales que surgen entre los actores involucrados.

\section{Gráfico 5. Sistemas sociohídricos}

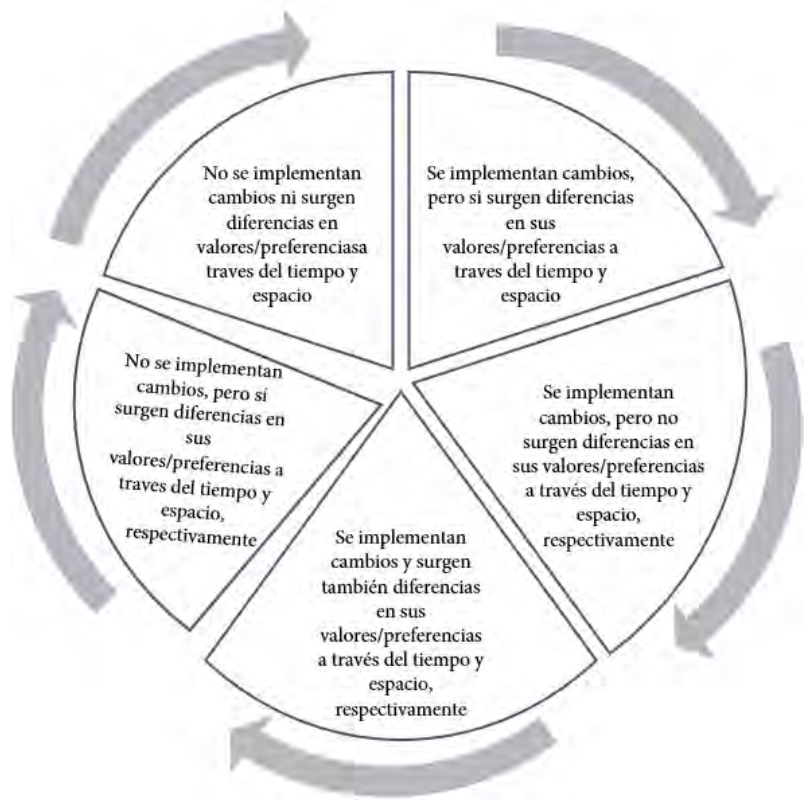

Fuente: Construido con base a Sivapalan, Murugesu y Blöschl, Günter, "Time scale interactions and the coevolution of humans and water", Water resources research, Canada, núm. 9, agosto, 2015.

149 Sivapalan, Murugesu y Blöschl, Günter, "Time scale interactions and the coevolution of humans and water", Water resources research, Canada, núm. 9, agosto, 2015, https://agupubs. onlinelibrary.wiley.com/doi/full/10.1002/2015WR017896 
La sociohidrología es un paradigma para el siglo XXI debido a que la dinámica en los procesos hídricos y sociales generan nuevos fenómenos sociales, culturales, políticos, económicos que configuran un hibrido. Las necesidades emergentes deben ser atendidas a partir de la comprensión de diversas ciencias y disciplinas, además de visualizar los alcances y límites a corto, mediano y largo plazo; estableciendo flexibilidad y transversalidad en su comprensión de forma holística y sostenible.

Ante la comprensión holística de las acciones humanas en aumento de manera sorprendente e impredecible para generar un conjunto de diversos desafíos de sostenibilidad del agua que deben incorporarse a nuevos enfoques de la ciencia y la gestión del agua; es indispensable basarse en las ciencias naturales, ciencias sociales y las humanidades para comprender la dinámica de adaptación y acoplamiento bidireccional entre el ser humano y el agua.

$\mathrm{Si}$ hablamos de problemas complejos en un marco de sostenibilidad, entonces debe configurarse e integrarse cultura, teorías y métodos científicos en la comprensión de la dinámica de los sistemas emergentes ${ }^{150}$. Al respecto es importante señalar el marco organizativo de la sociohidrología según Sivapalan y otros.

\section{Tabla 2. Marco organizativo de la sociohidrología}

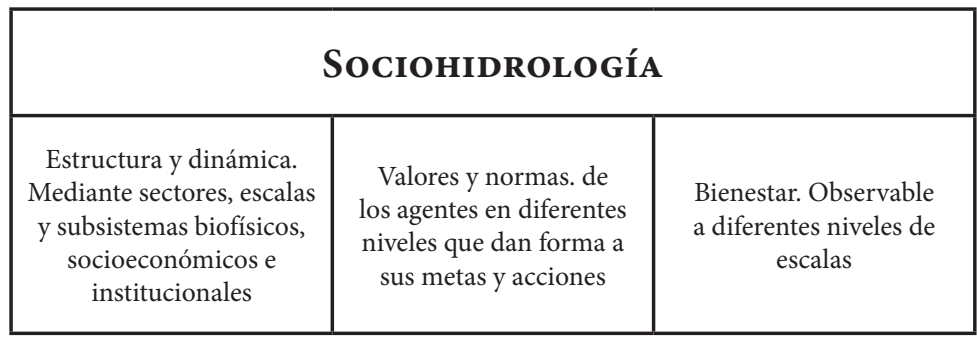

Fuente: Sivapalan, M., M. Konar, V. Srinivasan, A. Chhatre, A. Wutich, C. A. Scott, J. L. Wescoat, and I. Rodríguez-Iturbe, Socio-hydrology: Use-inspired water sustainability science for the Anthropocene, Earth's Future, 2, 2014, p. 226.

150 García Corrales, Lina, Mendez, Yhonattan, Avila, Humberto y Pacheco Carlos. Alternativa de análisis de causas y efectos hidrológicos de cambios en usos del suelo en cuencas de bosque seco tropical, Buenos Aires, Argentina, XXVIII Congreso Latinoamericano de Hidráulica, 2018. 
Sivapalan ${ }^{151}$ considera que la sociohidrología es una ciencia que procura considerar a las personas como una parte endógena del ciclo del agua, en la que se debe comprender su interacción con los múltiples procesos y estados del agua.

Como aspecto particular de la sociohidrología se enfoca en el estudio multidisciplinar que realiza de la coevolución de los seres humanos con el recurso hídrico y sus procesos de adaptación. Pretende ser una ciencia en la que, a partir de la observación y descubrimientos se proceda a una transformación de mejora del medio o contexto a corto, mediano o largo plazo.

De acuerdo a los nuevos esquemas la sociohidrología puede fortalecerse bajo las siguientes tres vías:

1. Sociohidrología histórica: describe el proceso histórico como aprendizaje reconstructor en acciones hídricas. Considera la evaluación del uso y gestión del agua con base a la gobernanza y tecnología.

2. Sociohidrología comparada: basada en la investigación de hidrología comparativa que caracteriza y aprende las similitudes y diferencias de cuencas de captación de lugares diversos, interpretándolo en términos de clima-paisajehumanos. Implica un análisis comparativo de la interacción entre el hombre y el agua a través del criterio socioeconómico, así como climáticos entre otros, comparando diferencia espacial o regional con los procesos y su dinámica temporal.

3. Proceso sociohidrológico: en el interés de asociar el análisis temporal y espacial establece estudiar en un grupo pequeño de personas su relación con el agua ${ }^{152}$ dado que la sociohidrología se trata de coevolución y retroalimentación que operan a múltiples escalas, es probable que las nociones de optimización

151 Murugesu Sivapalan, Hubert H. G. Savenije and Günter Blösch, "Socio-hydrology: A new science of people and water" Hydrological Processes, November, 2011.

152 Monitoreo de rutina, para obtener una visión más detallada de las relaciones causales. Involucra la recopilación de datos detallados de procesos hidrológicos y sociológicos involucrados, incluido el aprendizaje en tiempo real, para comprender las funciones del sistema humano-agua en el presente y poder predecir posibles trayectorias en el futuro. 
y funciones objetivo sean importantes y útiles, tal como lo han sido en ecohidrología.

Bajo los esquemas antes señalados, la interacción entre el medio natural, social, económico y político representan a nivel mundial cada vez más estragos con el recurso hídrico. Por ello, mediante la transdisciplinariedad se ahonda en abordar los problemas presentes para gestionarlos, atenderlos con perspectiva sostenible y resiliente previendo mediante acciones de política pública estragos mayores ante el estrés hídrico y otras afectaciones.

Finalmente, la seguridad hídrica converge con el impacto y percepciones de los ciudadanos y las acciones del Estado; ante ese panorama la sociohidrología a través de los modelos acoplados del sistema humano-agua, si bien aún no están preparados para anticipar las respuestas adaptativas de los diferentes actores a futuros cambios de infraestructura, sociales o de políticas. Armonizar modelos de sistemas sociales, económicos y naturales, teniendo en cuenta la diferencia fundamental en la complejidad de los modelos, las escalas de los procesos dominantes, los requisitos de datos, la evaluación de su desempeño y la aplicabilidad de los modelos. para lo que pretendían, siguen siendo desafíos importantes ${ }^{153}$. En esa sintonía el sistema sociohidrológico analiza a todos los actores involucrados con el agua en todos los ámbitos con el objetivo de reconoce causas y efectos que aporten a la mejoría de las condiciones de la relación ser humano-agua.

153 V. Srinivasan, M. Sanderson, M. Garcia, M. Konar, G. Blöschl \& M. Sivapalan. "Prediction in a socio-hydrological world", Hydrological Sciences Journal, 62:3, 338-345, DOI: $10.1080 / 02626667.2016 .1253844$ 

III.

Aproximación ECONÓMICA 



\section{Economía verde}

Definido por Pearce, Markandya y Barbier como "un sistema De actividades económicas relacionadas con la producción, distribución y consumo de bienes y servicios que resulta en mejoras del bienestar humano en el largo plazo, sin comprometer a las generaciones futuras a riesgos ambientales y escasez ecológicas significativas"154. Esta definición se asocia al desarrollo sostenible con el objeto de garantizar a las generaciones futuras un estado de bienestar asegurado con el mínimo de vida digna.

El PNUMA define una economía verde como aquella que resulta en la mejora del bienestar del ser humano y la equidad social, al mismo tiempo que reduce significativamente los riesgos ambientales y la escasez ecológica ${ }^{155}$. Esta descripción apunta a un proceso sostenible pero además ve por disminuir el riesgo en todos los ámbitos.

Se constituye de forma directa bajo los criterios de los Gobiernos en el sentido de que estos deberán dictar y ejecutar políticas e invertir en la ejecución de las acciones ${ }^{156}$. Proclama por procesos de inversión

154 William Pearce, David, Markandya, Anil, Burr Barbier, Edward, Earthscan, Edward. Blueprint for a Green Economy, Earthscan Publications Ltd, London 1989, p. 61-65.

155 Hartley Rocío. "La ONU clama por una economía verde en todo el mundo", Revista mensual sobre la actualidad ambiental, abril 2012, p. 16.

156 Arguedas, Carlos. "Río+20 hacia la utopía de la economía verde", Revista mensual sobre la actualidad ambiental, mayo 2012, p. 13. 
entre el sector privado y público en el mercado en un ámbito de acción social apoyada por el crecimiento científico-tecnológico.

La construcción de la economía parte de un proceso de transición en concordancia con el desarrollo sostenible, al respecto Conte y $\mathrm{D}^{\prime}$ Elia $^{157}$ construyen una descripción de los distintos conceptos basado en la economía verde.

Tabla 3. Definición de diversos conceptos verdes

\begin{tabular}{|c|c|c|}
\hline Concepto & Fuente & Definición \\
\hline Desarrollo sostenible & $\begin{array}{l}\text { CMUAd (1987), punto } 3 \text {, } \\
\text { pórrofo } 27\end{array}$ & $\begin{array}{l}\text { "Está en manos de la humanidad hacer que el desarrollo } \\
\text { sea sostenible, duradero, o sea, asegurar que satisfoga las } \\
\text { necesidades del presente sin comprometer la capacidad de } \\
\text { las futuras generaciones para sotisfocer las propias". }\end{array}$ \\
\hline Economía verde & PNUMA (2011), pógina 9 & $\begin{array}{l}\text { "...una economía verde debe mejorar el bienestar del } \\
\text { ser humano y la equidad sociol, o la vez que reduce } \\
\text { significativamente los riesgos ambientoles y las escaseces } \\
\text { ecológicas. En su formo mós bósica, una economía verde } \\
\text { sería aquella que fiene bajos emisiones de corbono, utiliza } \\
\text { los recursos de formo eficiente y es socialmente incluyente". }\end{array}$ \\
\hline Grecimiento verde & $\begin{array}{l}\text { OECD (2009), Consideraciones, } \\
\text { pógino } 1 \text { (ocknowledging that } \\
\text { "green" and "growth" can go } \\
\text { hand-inthond) }\end{array}$ & $\begin{array}{l}\text { "Green growth will be relevant going beyond the current } \\
\text { crisis, addressing urgent challenges induding the fight } \\
\text { against climate chonge and environmental degradation, } \\
\text { enhancement of energy security, and the creation of new } \\
\text { engines for economic growth". }\end{array}$ \\
\hline $\begin{array}{l}\text { Grecimiento verde } \\
\mathrm{e} \text { inclusivo }\end{array}$ & World Bank (2012), pógina 2 & $\begin{array}{l}\text { "Indusive green growth is not a new paradigm. Rather, } \\
\text { it aims to operationalize sustainable development by } \\
\text { reconciling developing countries' urgent need for rapid } \\
\text { growth and poverty olleviation with the need to avoid } \\
\text { irreversible and costly environmental damage". }\end{array}$ \\
\hline
\end{tabular}

Fuente: Conte y D'Elia, 2018, p. 65.

La tabla anterior señala la convergencia entre categorías de lo que implica desarrollo sostenible y economía verde de las cuales se puede resaltar que, si bien están planteados en una visión economista, se apoya de procesos equitativos que coadyuven al medio ambiente $y$ a la sociedad.

157 Conte Grand, Mariana y D'Elia, Vanesa. "Desarrollo sostenible y conceptos verdes" Revista Problemas del Desarrollo, enero-marzo 2018. http://www.scielo.org.mx/pdf/prode/ v49n192/0301-7036-prode-49-192-61.pdf 
Becker ${ }^{158}$ identifica una serie de conceptos de economía verde que a continuación se detallan. La CEPAL sustenta la economía verde desde aquella que emite poco carbono, uso eficiente de los recursos, socialmente incluyente. La OCDE la orienta como aquella que fomenta crecimiento y desarrollo económico asegurando la continuidad de los bienes naturales, recursos y servicios ambientales garantizando el bienestar. La ONU Medio Ambiente la define como aquella que procura la mejora del bienestar humano y la equidad social, reduciendo riesgos ambientales y escases ecológica. En el escenario de Rio+20 "El futuro que queremos" la contextualiza bajo el panorama del desarrollo sostenible y erradicación de pobreza procurando menores consecuencias negativas, mejorando el aprovechamiento de recursos y reducción de los desechos.

La economía verde se convierte en un modelo que promueve el crecimiento, la creación de ingresos y puestos de trabajo, "empleos verdes", que procura generar un cambio en la interacción entre progreso económico y sostenibilidad ambiental, en particular si la riqueza se mide teniendo en cuenta los bienes naturales y no únicamente la productividad. Junto a lo anterior también aporta de manera sustancial en la reducción de la desigualdad social entre países y en la erradicación de la pobreza en el mundo ${ }^{159}$. En ese tenor, prevalece el compromiso de vincular la equidad social con medidas que influyan en inversiones y decisiones de las personas e industria de forma correlacional.

El recurso hídrico en la economía verde, se trata de apoyarse y aplicar la tecnología en el tratamiento, distribución y recuperación de aguas residuales industriales por ejemplo para la irrigación ${ }^{160}$.

La economía verde adquiere un seguimiento estricto toda vez que los países están comprometidos con la agenda 2030. Deben ser compatibles con el derecho internacional, respetando la soberanía

158 Becker, Ralf. Indicadores de economía verde y de las ODS, División de Estadísticas de Naciones Unidas, Guatemala, 2018. https://www.cepal.org/sites/default/files/courses/ files/2018-01_1.1_metodologia-indicadores-economia-verde.pdf

159 Vargas Pineda, Oscar Iván, Trujillo González, Juan Manuel y Torres Mora, Marco Aurelio. "La economía verde: un cambio ambiental y social necesario en el mundo actual." Revista de Investigación Agraria y Ambiental, julio-diciembre, 2017, p. 183.

160 ONU, Agua e industria en la economía verde, Programa de ONU-Agua para la promoción y la comunicación en el marco del Decenio (UNM-DPAC), ONU, España, 2011, p. 2. g 
nacional sobre sus recursos naturales, promoviendo el crecimiento económico sostenido e inclusivo, respetando los derechos humanos, las necesidades de los países en desarrollo, fortalecer la cooperación internacional, y reducir la dependencia y la brecha tecnológica entre los países desarrollados y en desarrollo. Para lograr el desarrollo sostenible mundial deben producirse cambios fundamentales, entre otros, en la manera en que las sociedades producen y consumen, por lo que todos los países deben fomentar modalidades de consumo y producción sostenibles ${ }^{161}$. Por lo anterior, los gobiernos deben alinearse al estado de bienestar social y disminuir el rango o estándar que tiene en el mercado.

\section{El agua en el sistema económico neoliberal}

En la resolución 64/292 de la Asamblea General dictada en la $108^{a}$ Sesión Plenaria de la Asamblea General de la ONU, este órgano emite dos resolutivos trascendentales; el primero de ellos, el reconocimiento literal del derecho al agua potable y al saneamiento como un derecho humano esencial para el pleno disfrute de la vida y de todos los derechos; el segundo, refiere abastecer a toda persona acceso al agua potable y al saneamiento expresando claramente la necesidad de que este acceso al servicio sea económico de lo contrario no se garantizaría el acceso real a este derecho ${ }^{162}$.

Se considera entonces el costo que tiene el servicio de gestión del recurso hídrico, sin embargo el costo del mismo se convierte en estrategias políticas que advierten como obligación del derecho al agua tener que realizar el pago, en caso de no realizarlo se priva de un derecho fundamental a la persona, es entonces una dicotomía reglamentaria de establecer sanciones y reglas que el propio ser humanos crea, es de cierta forma imprudente considerar diferencias o privilegios del servicio y acceso del agua en la sociedad quebrantando el principio de equidad.

161 Martínez, Adriana Norma y Porcelli, Adriana Margarita. "Reflexiones sobre la economía verde. El New Deal ecológico mundial. Lex Facultad de derecho y ciencia política.

162 Rentería Medina, Flor Estela (Diputada), Exposición de Motivos, Iniciativa que reforma el artículo 4o. de la Constitución Política de los Estados Unidos Mexicanos, del Grupo Parlamentario del PRI, Gaceta Parlamentaria, Número 4382-II, Palacio Legislativo de San Lázaro, a 13 de octubre de 2015. 
Loanterior, remite al derecho humano al agua yla interdependencia e indivisibilidad con otros derechos como garantía de acceso a toda persona satisfaciendo a partir del mínimo las necesidades y libertades para una vida digna.

El grado extremo con que un bien necesario para la vida puede ser etiquetado y hasta banalizado como un insumo más del binomio producción consumo. El agua, como bien lo aclaró el tribunal de la Haya, es un bien público y nadie puede aspirar a tener el control del mismo ${ }^{163}$.

El Decenio Internacional para la acción "El agua fuente de vida 2005-2015"164 encuadró un sistema denominado economía verde, la cual es una economía que conlleva una mejora del bienestar de las personas y la reducción de las desigualdades a largo plazo, al tiempo que evita exponer a las generaciones futuras a riesgos medioambientales y escaseces ecológicas significativos. El propio sistema establece criterios que le puedan permitir el desarrollo y permanencia de la venta del agua mediante sistemas legitimados y aprobados por sectores de dominio con interés económicos.

El agua interviene en la cadena de valor de la energía en tres momentos: en la producción de la materia prima; en su transformación para ser consumidas y finalmente cuando se entregan a sus consumidores. En esta última fase no se consume agua directamente, sólo en el sistema de distribución ${ }^{165}$.

Se ha descrito como se ha ido estructurando mediante las políticas públicas la economía verde enmarcada en el neoliberalismo, para lograr éxito en la promoción de la privatización del agua, el Banco Mundial y las grandes empresas del agua requerían sumar el apoyo de Naciones Unidas, e instaurar una institucionalidad global para la promoción de sus intereses. En una importante conferencia la ONU en Dublín en enero de 1992, a la que asistieron funcionarios de gobiernos y ONG de cien naciones, se declaró que el agua tiene

163 Aguilar Obregón, Erick Alejandro Rafael, "Genealogía del Derecho al Agua en México, en Derecho Humano al agua", Revista Impluvium, publicación digital de la Red del Agua UNAM, número 4, enero-junio 2015, p. 10.

164 Véase http://www.un.org/spanish/waterforlifedecade/green_economy.shtml.

165 Guerrero, Manuel y Schifter, Isaac, La huella del agua, México, FCE, 2014, p. 115. 
un "valor económico" en todos sus "usos competentes", y que debiera ser reconocida como un "bien económico". Como se refirió en el apartado de recurso natural, las diversas instituciones, organizaciones mundiales y nacionales adoptaron ese patrón de ideas asentándolos en Tratados Internacionales, convenciones, acuerdos, agendas, etc., que han permeado como formas de vida en las diversas culturas de las sociedades, perdiendo la naturaleza de bien común e interés público.

Shiva Vandana ${ }^{166}$ señala que el recurso implicaba una relación entre los seres humanos y la naturaleza de reciprocidad y regeneración, posteriormente en la revolución industrial, existió una transformación en el que la naturaleza se convirtió en materia prima del mercado, siendo requerida como insumo.

La naturaleza se ha convertido en un depósito de materias primas que esperan su transformación en insumos para la producción de mercancías ${ }^{167}$, las cuales adquieren una explotación económica; se considera entonces que pasa a formar parte de una serie de objetos o materiales manejables dejando a un lado la vida de ese recurso natural.

La utilidad e importancia de los recursos naturales en el sistema neoliberal ${ }^{168}$ ha permitido que grandes sociedades se desarrollen y evolucionen conformándose, así como potencias mundiales consolidadas de acuerdo a medios de producción y capital intelectual, humano y económico que gestionan la administración de los recursos de acuerdo al mercado de la oferta y demanda. El interés de permanencia y estabilidad dentro del mercado ha desencadenado

166 W. Sachs (editor), Diccionario del desarrollo. Una guía del conocimiento como poder, Perú, PRATEC, 1996, pp. 318, 319 y 399.

167 Meeker, Joseph, Misused Resources (recursos maltratados), resurgence, no. 125, diciembre 1987.

168 Se considera pertinente analizar el papel que empieza a jugar la Organización Mundial del Comercio (OMC) la cual a través del comercio de bienes y servicios van creando un sistema de mercado global y neoliberal como política económica. Pudiendo ejercer un control macroeconómico mediante grupos reducidos y cerrados con intereses únicos y propios basados en el valor agregado de esos bienes y servicios, en este caso el recurso hídrico como un medio vital de subsistencia no sólo de la especie humana sino del posicionamiento, mantenimiento y crecimiento de este recurso como mercancía (privatización). 
que las grandes potencias determinen el futuro del resto de los países $^{169}$.

La supremacía de estos recursos naturales como materia prima de medios de producción refiere de mayor interés al recurso hídrico, representando así el uso de la misma para poder realizar todo el proceso de producción. Se confrontan dos visiones del agua la primera como un recurso hídrico y la segunda supone el concepto a partir de ser una mercancía. Convirtiéndonos o siendo entonces una sociedad de doble personalidad en la aplicabilidad del recurso hídrico haciendo efectivo un binomio entre lo público y privado, entre derechos y mercancía, en ser ciudadano y cliente ${ }^{170}$.

Irina Bokova, en el mensaje del día mundial del agua de año 2016 enmarca que en la coyuntura del cambio climático y escasez de agua se requerirá de mayor inversión en las áreas de ciencia, tecnología e innovación.

Aunado a esa inversión se poyará a los servicios hídricos y de infraestructura el cual se debe planificar con los sectores que de forma directa les atañe, como el agrícola, energético e industrial. Se considera entonces que la UNESCO hace referencia al bien común como un sólo estado estable del sector primario e industrial no hace referencia a un bienestar de vida digna para las personas, se enmarca dentro de un escenario productivo en el que el agua es de suma importancia para producir y abastecer el proceso que conlleva cada una de las actividades, es meramente facilitadora del mecanismo de producción.

El agua como mercancía puede concebirse desde tres características; la primera reside en la estimación del precio, en el costo de abastecimiento en sus diversas acepciones ya sea

$169 \mathrm{Al}$ respecto se ha enunciado la pretensión de la Ley de Aguas Nacionales con la Ley de Aguas de Korenfeld, encubriendo el interés de un sector minoritario por la apropiación del agua a partir del poder de tomar decisiones a espaldas de la ciudadanía y ejecutarlas con la fuerza pública; privatización y concesiones a grandes obras hidráulicas; sobreexplotación de cuencas y acuíferos; despojo o desplazo de pueblos indígenas en zonas con grandes proporciones de agua; acceso al derecho humano al agua a partir de un mínimo; proporcionar legítimamente el agua para uso minero y fracking; continuar proporcionando mala calidad del agua; exponer situación real de las condiciones del agua.

170 Bakker Karen, Bienes comunes versus mercancía: el debate del derecho humano al agua, en el derecho al agua, México, Trillas, 2014, p. 46. 
agricultura, industria o consumo humano. La segunda potencializa y empodera el mercado a partir de la "eficiencia y calidad" que otorga el abastecimiento de agua a través de la privatización del agua como servicio que provee el recurso. La tercera es precisamente la propiedad privada. Existe una visión mercantilista de costo-beneficio, precios y permanencia en el mercado de acuerdo a la oferta y demanda ${ }^{171}$.

Barlow Maude ${ }^{172}$ destaca la forma de comercializar el recurso hídrico a través de la producción, él refiere el término de comercio virtual del agua al recurso hídrico consumido en la producción de cosechas o productos manufacturados para la exportación. Llega a considerarse virtual porque ya no está contenida en el producto, aunque se usó una gran cantidad de agua en su proceso productivo. Si un país exporta a otro un producto que requiere gran cantidad de agua para su producción, está exportando agua en una forma virtual, aunque técnicamente no se esté vendiendo agua.

En el caso de México, en la Ley Federal de Derechos ${ }^{173}$ existe una obligación de pago del derecho sobre el agua, ya sea persona física o moral que use, explote o aproveche aguas nacionales, de hecho o al amparo de títulos de asignación, concesión, autorización o permiso que haya sido otorgados por el Gobierno Federal, de acuerdo a la zona de disponibilidad de agua, cuenca o acuífero en que se efectúe su extracción de acuerdo a un parámetro de cuota establecida ${ }^{174}$. El supuesto ingreso obtenido como "recaudación" por explotación, uso o aprovechamientos de aguas nacionales, 300 millones de pesos se remiten al Fondo Forestal Mexicano para el desarrollo y operación de Programas de Pago por Servicios Ambientales.

171 Langford, Malcolm y Khalfan, Ashfad, "Introducción al agua como derecho humano", en La gota de la vida: hacia una gestión sustentable y democrática del agua, México, Böll, 2006, pp. 31-34.

172 Barlow, Maude, El convenio azul, la crisis global del agua y la batalla futura por el derecho al agua, trad. de Magali Meneses, Canadá, HEINRICH BÖLL STIFTUNG, 2009, p. 24.

173 Ley Federal de Derechos, 2014, artículo 222- 231-A Capítulo VIII “Agua”.

174 La zona de disponibilidad vigente esta numerada del 1 al 4 , ya sea por aguas superficiales o aguas subterráneas. En donde la zona cuatro representa el menor pago de m3 que equivale en aguas superficiales $\$ 1.6611$, en aguas subterráneas $\$ 1.8998$, el nivel 3 en aguas superficiales tiene un costo de $\$ 2.1723$, en aguas subterráneas $\$ 2.6135$, el nivel 2 aumenta más del doble en ambas, en aguas superficiales \$ 6.6252 y en aguas subterráneas $\$ 7.5060$ y finalmente la zona 1 tiene un costo de $\$ 14.3910$ en aguas superficiales y \$19.3914 en aguas subterráneas. 
La mercantilización del agua responde a un valor asignado por los propios sujetos el cual tiene un valor mercantil, convirtiéndose en un bien escaso, aunque en principio se considere como bien común, social, público y gratuidad en el que el coste estaba cubierto o financiado en la colectividad. 



\section{Bibliografía}

ABOITES AGUILAR, Luis, De bastión a amenaza. Agua, políticas públicas y cambio institucional en México, 1974-2001, en El futuro del agua en México, coords. Graizbord, Boris y Arroyo Alejandre, Jesús, Universidad de Guadalajara, México, COLMEX, PROFMEX, 2011.

AGUDELO C., Ruth Marina. El agua, recurso estratégico del siglo XXI, Revista Facultad Nacional de Salud Pública, vol. 23, núm. 1, enero-junio, 2005 Colombia.

AGUILAR OBREGÓN, Erick Alejandro Rafael, "Genealogía del Derecho al Agua en México, en Derecho Humano al agua", Revista Impluvium, publicación digital de la Red del Agua UNAM, número 4, enero-junio 2015.

ARGUEDAS, Carlos. "Río+20 hacia la utopía de la economía verde" Revista mensual sobre la actualidad ambiental, mayo 2012.

BALL Philip, H2O una biografía del agua, fondo de cultura económica, trad. De José Aníbal Campos, México, FCE TURNER, 2010.

BAKKER Karen, Bienes comunes versus mercancía: el debate del derecho humano al agua, en el derecho al agua, México, Trillas, 2014.

BARLOW, Maude, El agua nuestro bien común, hacia una nueva narrativa del agua, Canadá, HEINRICH BÖLL STIFTUNG, 2009.

, El convenio azul, la crisis global del agua y la batalla futura por el derecho al agua, trad. de Magali Meneses, Canadá, HEINRICH BÖLL STIFTUNG, 2009 
BECK, Ulrich, La sociedad del riesgo, hacia una nueva modernidad, Barcelona, Paidós, 1998.

BECKER, Ralf. Indicadores de economía verde y de las ODS, División de Estadísticas de Naciones Unidas, Guatemala, 2018. https:// www.cepal.org/sites/default/files/courses/files/2018-01_1.1_ metodologia-indicadores-economia-verde.pdf

BLACK Maggie, El secuestro del agua, la mala gestión de los recursos hídricos, España, ed. Bigsa, 2005.

CARMONA CUENCA, Encarna, Los derechos sociales de prestación y el derecho a un mínimo vital, Revista Nuevas políticas públicas, España, núm. 2.

CÉSPEDES HERNÁNDEZ, Juan José. Pobreza y escasez de agua, en el México del siglo XXI, México, Novum, 2011.

COSSÍO DÍAZ, José Ramón, Derecho y ciencia, Tirant lo Blanch, México, 2015.

los delitos ambientales, México, FCE, 2014.

et. al., (coord.), Defensa legal contra y MEZA FONSECA, Emma (coords.)

Delitos contra el ambiente u gestión ambiental en el Código Penal Federal, México, Bosch, 2014.

COMITÉ ESCR, Observación General no. 15 el Derecho al Agua.

COMISIÓN MUNDIAL DE REPRESAS, REPRESAS Y DESARROLLO, un nuevo marco para la toma de decisiones, el reporte final de la comisión mundial de represas, Reino Unido, 2000 .

CONVENCIÓN DE LA OIT N¹61 de 1985.

CONVENCIÓN SOBRE LOS DERECHOS DEL NIÑO (CDN), Asamblea General de las Naciones Unidas, Aprobada el 20 de noviembre de 1989.

CONVENCIÓN SOBRE LA ELIMINACIÓN DE TODAS LAS FORMAS DE DISCRIMINACIÓN CONTRA LA MUJER 
(CEFDM), Asamblea General de las Naciones Unidas Aprobada el 18 de diciembre de 1979.

CONVENCIÓN sobre los Derechos de las Personas con Discapacidad (CDPD).

CONTE GRAND, Mariana y D'ELIA, Vanesa. “Desarrollo sostenible y conceptos verdes" Revista Problemas del Desarrollo, eneromarzo 2018. http://www.scielo.org.mx/pdf/prode/v49n192/03017036-prode-49-192-61.pdf

CUMBRE DE LA ONU sobre los Objetivos de Desarrollo del Milenio, Sede Central de las Naciones Unidas, Nueva York, del 20 al 22 de septiembre de 2010.

DICCIONARIO IBEROAMERICANO DE DERECHOS HUMANOS Y FUNDAMENTALES, Programa Regional de Apoyo a las Defensorías del Pueblo en Iberoamérica.

DOF: 12/08/2016. RECOMENDACIÓN General No. 27/2016 sobre el derecho a la consulta previa de los pueblos y comunidades indígenas de la República Mexicana. http://www.dof.gob.mx/ nota_detalle.php?codigo $=5447796 \&$ fecha $=12 / 08 / 2016$

DOWDOR, Ladislau, La reproducción social, 1ra. Ed., México, siglo XXI, 1999.

FERNÁNDEZ JÁUREGUI, Carlos A., El agua como fuente de conflictos: repaso de los focos de conflictos en el mundo, afters internacionals, núm. 45-46, fundación CIDOB, 1999.

FOOD AND AGRICULTURE ORGANIZATION OF THE UNITED NATIONS (FAO), "China's environment policy", Revista Unasylva, EE.UU., No. 134, vol., 33, 1981.

GALINDO MENDOZA, María G. "Justicia Ambiental. Entre la utopía y la realidad social Culturales" México, Revista Culturales, núm. 1, vol. III, enero-junio de 2015. Recuperado de http://www. redalyc.org/articulo.oa?id $=69438994008$ 
GALLOPÍN, Gilberto, Ecología y ambiente, los problemas del conocimiento y la perspectiva ambiental del desarrollo, México, siglo XXI, 1986.

GARCÍA, Aniza, El derecho humano al agua, México, ed. trotta, 2008.

GARCÍA CORRALES, Lina, MENDEZ, Yhonattan, AVILA, Humberto y PACHECO Carlos. Alternativa de análisis de causas y efectos hidrológicos de cambios en usos del suelo en cuencas de bosque seco tropical, Buenos Aires, Argentina, XXVIII Congreso Latinoamericano de Hidráulica, 2018.

GETCHES, H, David, Derechos de los Pueblos indígenas al agua y normas internacionales, pp. 1 y 2.

GÓMEZ TREJO, Omar, Los derechos a la alimentación, al agua, a la salud y a la vivienda contenidos en el Artículo 4to. Constitucional a la luz del Derecho Internacional de los Derechos Humanos en México. En: FERRER MAC-GREGOR Poisot, Eduardo, Caballero Ochoa, José Luis, et. al. Derechos Humanos en la Constitución: Comentarios de Jurisprudencia Constitucional e Interamericana. México, UNAM-Suprema Corte-Konrad Adenauer Stiftung.

GUERRERO, Manuel y SCHIFTER, Isaac, La huella del agua, México, FCE, 2014.

GRAIZBORD, Boris y ARROYO Alejandre, Jesús (coords.), El futuro del agua en México, México, COLMEX, PROFMEX, 2011.

HARTLEY Rocío. "La ONU clama por una economía verde en todo el mundo" Revista mensual sobre la actualidad ambiental, abril 2012.

HERRERA CARRILLO, Ricardo. Las corporaciones autónomas regionales y la justicia ambiental, en Justicia Ambiental, las acciones judiciales para la defensa del medio ambiente, Colombia, CAR, 2001. 
HOOGESTEGER, Jaime y Urteaga, Patricia, Agua e inequidad: discursos, políticas y medios de vida en la región andina, Instituto de Estudios Peruanos, Lima, 2013.

INTERNATIONAL GLOSSARY OF HYDROLOGY. World meteorological organization, WMO-No.385, UNESCO.

INFORME: Nuestro futuro común, Comisión Mundial sobre el Medio Ambiente y el Desarrollo, 1987.

JALIFE-RAHME, Las guerras globales del agua, privatización y fracking, México, Orfila, 2015.

KLARE T., Michael. Resource wars: the new landscape of global conflict, owl books, The United States of America, 2002.

LANGFORD, Malcolm y KHALFAN, Ashfad, "Introducción al agua como derecho humano", en La gota de la vida: hacia una gestión sustentable y democrática del agua, México, Böll, 2006.

Ley General de Desarrollo Social.

Ley Federal de Derechos.

Ley de Aguas Nacionales.

LOUCKS, D. P., E. VAN Beek, J. R. Stedinger, J. P. Dijkman, and M. T. Villars, Water Resources Systems Planning and Management: An Introduction to Methods, Models and Applications, Paris, UNESCO, 2005.

MADRAZO Jorge y Cottom, artículo $4^{\circ}$, Enciclopedia de Derechos Humanos del Pueblo Mexicano, México a través de sus Constituciones, Tomo1, artículos $1^{\circ}-15$, México, Porrúa, SCJN, IFE, Legislatura Cámara de Diputados, Senado de la República, 2012.

MANCISIDOR, Mikel, El derecho humano al agua: situación actual y retos de futuro, España, ed. Icaria, 2008.

MARTÍNEZ, Adriana Norma y PORCELLI, Adriana Margarita. "Reflexiones sobre la economía verde. El New Deal ecológico mundial. Lex Facultad de derecho y ciencia política. 
MARQ De Villiers. Water: the fate of our most precious resource, Nueva York, Houghton Mifflin, 2000.

MEEKER, Joseph, Misused Resources (recursos maltratados), resurgence, no. 125, diciembre 1987.

MONGE, Cristina, La naturaleza del agua como recurso, perspectiva social, económica e institucional de una gestión integral, Congreso Ibérico sobre gestión y planificación del agua, Tortosa, diciembre, 2004.

MURUGESU Sivapalan, HUBERT H. G. SAVENIJE and GÜNTER Blösch, "Socio-hydrology: A new science of people and water" HYDROLOGICAL PROCESSES, November, 2011.

NACIONES UNIDAS. Resolución aprobada por la Asamblea general, 9 de febrero de 2004, quincuagésimo octavo período de sesiones, 58/217, decenio internacional para la acción "el agua, fuente de vida", 2005-2015.

NACIONES UNIDAS, Justicia transicional y derechos económicos, sociales y culturales, Nueva York y Ginebra, 2014.

NACIONES UNIDAS, Justicia transicional y derechos económicos, sociales y culturales, Nueva York y Ginebra, 2014.

ONU-Water Analytical Brief on Water Security and the Global Water Agenda, 2013.

ONU, Agua e industria en la economía verde, Programa de ONUAgua para la promoción y la comunicación en el marco del Decenio (UNM-DPAC), ONU, España, 2011.

PLAN NACIONAL DE DESARROLLO 2019-2024. Diario Oficial de la Federación, Secretaría de Gobernación, Andrés Manuel López Obrador, México, 2019.

PETRELLA, Riccardo, El manifiesto del agua para el siglo XXI, Barcelona, ICARIA, 2004.

RENTERÍA MEDINA, Flor Estela (Diputada), Exposición de Motivos, Iniciativa que reforma el artículo 4o. de la Constitución Política de los Estados Unidos Mexicanos, del Grupo Parlamentario del 
PRI, Gaceta Parlamentaria, Número 4382-II, Palacio Legislativo de San Lázaro, a 13 de octubre de 2015.

RESTREPO GUTIÉRREZ, Elizabeth y ZÁRATE YEPES, Carlos Alberto, El mínimo vital de agua potable en la jurisprudencia de la Corte Constitucional colombiana, Opinión Jurídica, vol. 15, núm. 29, enero-junio, 2016.

RESOLUCIÓN A/RES/64/292, Asamblea General de las Naciones Unidas, Comité de Derechos, Julio de 2010.

RÍOS SARMIENTO, Melissa; Aguirre Fajardo, Alejandra María; Gonzaga Valencia Hernández, Javier, "Desafíos de la justicia ambiental y el acceso a la justicia ambiental en el desplazamiento ambiental por efectos asociados al cambio climático", Revista Luna Azul, núm. julio-diciembre,

ROBIN Clarke, Water: the international crisis, Cambridge, Massachussetts, MITT Press, 1993.

ROBLERO GONZÁLEZ, Juan Ángel, et. al., "El acceso a la justicia ambiental y la posibilidad de implantación de tribunales ambientales en Chiapas, México" México, Revista Ra Ximhai, núm. 2, vol. 8, mayo-agosto de 2012, pp. 175-180,

http://www.redalyc.org/articulo.oa?id=46123333018

SILVA HERNÁNDEZ, Francisca, "Mecanismos Alternativos de Solución de Controversias como vía colaborativa en la responsabilidad ambiental" en Islas Colín, Alfredo y Argáez de los Santos, Jesús Manuel, Derechos Humanos, un escenario comparativo entre los sistemas universal, regional y nacional, México, Flores editores, 2016.

SIVAPALAN, Murugesu y BLÖSCHL, Günter, “Time scale interactions and the coevolution of humans and water", Water resources research, Canada, núm. 9, agosto, 2015. https://agupubs. onlinelibrary.wiley.com/doi/full/10.1002/2015WR017896

SULTANA, Farhana y LOFTUS, Alex, El derecho al agua, México, Trillas, 2014. 
TESIS: II.1o.A.110, Semanario Judicial de la Federación y su Gaceta, Novena Época, t. XXII, noviembre de 2005.

TESIS: VI.3o.A.1 CS (10a.), Semanario Judicial de la Federación y su Gaceta, Décima Época, t. II, julio de 2015.

TESIS: XI.1o.A.T.1 K (10ª), Semanario Judicial de la Federación y su Gaceta, Décima Época, t. 3, septiembre de 2012.

TESIS I.9Po.69 P (10a), Semanario Judicial de la Federación y su Gaceta, Décima Época, t. IV, noviembre de 2014.

TORRES BERNARDINO, Lorena, Sistema Lerma: una visión política en la gestión pública del agua, ¿solución estatal o federal? México, IAPEM, 2014.

TOWERS, G. "Applying the Political Geography of Scale: Grassroots Strategies and Environmental Justice", The professional geographer, 2000, Vol. 52, núm. 1.

UNESCO, IHP/2012/IHP-VIII/1, Plan Estratégico PHI-VIII 20142021.

UNESCO/OEA-Programa SARM Américas, Acuíferos Transfronterizos de las Américas, Estrategia regional para la evaluación y gestión de los sistemas acuíferos transfronterizos en las Américas, Montevideo, 2015.

UNESCO, El derecho humano al agua: situación actual y retos de futuro, Barcelona, Icaria, 2008.

UNITED NATIONS. Department of Economics and Social Affairs, Population Divison, World Population Prospects: The 2015 Revision, Key Findings and Advance Tables. New York, 2015.

VALENCIA HERNÁNDEZ, Javier Gonzaga, et. al., "Desafíos de la justicia ambiental y el acceso a la justicia ambiental en el desplazamiento ambiental por efectos asociados al cambio climático", Revista Luna Azul, Colombia, núm. 41, juliodiciembre de 2015. Recuperado dehttp://www.redalyc.org/ articulo.oa?id=321739268018 
"El derecho de

acceso a la justicia ambiental y sus mecanismos de aplicación en Colombia" tesis doctoral, Universidad de Alicante, 2011.

VANDANA, Shiva, Las guerras del agua, México, siglo XXI, 2013.

Las guerras del agua, privatización, contaminación y lucro, México, siglo XXI, 2003.

, Recursos, en diccionario del desarrollo, una guía del conocimiento como poder W. Sachs (editor), Perú, PRATEC, 1996.

VARGAS PINEDA, Oscar Iván, TRUJILLO GONZÁLEZ, Juan Manuel y TORRES MORA, Marco Aurelio. La economía verde: un cambio ambiental y social necesario en el mundo actual. Revista de Investigación Agraria y Ambiental, julio-diciembre, 2017.

VARGAS, Ramón, Territorios del agua-vida: cultura y democracia, en Cultura del agua en México, México, MAPORRUA, 2012.

VERAZA, Jorge, Economía y política del agua, México, Itaca, 2007.

V. Srinivasan, M. Sanderson, M. Garcia, M. Konar, G. Blöschl \& M. Sivapalan. "Prediction in a socio-hydrological world" Hydrological Sciences Journal, 62:3, 338-345, DOI: $10.1080 / 02626667.2016 .1253844$

WEBER, Max, Estructuras de poder, 4ta.Ed., México, FONTAMARA, 2012.

WILLIAM PEARCE, David, MARKANDYA, Anil, BURR Barbier, Edward, EARTHSCAN, Edward. Blueprint for a Green Economy, Earthscan Publications Ltd, London 1989.

WENZ, P.S. Environmental Justice, State University of New York Press, 1988, Albany

W. Sachs (editor)., Diccionario del desarrollo, una guía del conocimiento como poder, Perú, PRATEC, 1996. 

Este libro se terminó de imprimir en el mes de XXXX de XXXX en los talleres de XXXXXXXX, ubicados en la ciudad de XXXXXXXXXX (Colombia).

Las fuentes utilizadas hacen parte de la familia tipográfica Minion Pro. 


Este libro sobre las "Dimensiones sociales y económicas del uso del recurso hídrico" toma tres importantes temas de discusión: el derecho humano al medio ambiente, agua, enfoques sistemáticos y aproximación económica. De este modo, ofrece tres perspectivas para abordar el marco legal y fortalecimiento institucional, la importancia de la definición del agua desde diferentes ángulos y finalmente desde el punto de vista económico como se define y estudia el agua dada su escasez y en consecuencia necesaria gestión.

Los recursos hídricos se encuentran bajo una presión sin precedentes debido al crecimiento poblacional en gran parte de los países, lo que ha incrementado la demanda de agua para consumo humano y actividades productivas, particularmente la actividad agrícola, comprometiendo la disponibilidad del agua para el 2030. Por su parte, el cambio climático a colocado estrés hídrico alterando los ciclos hidrológicos que a su vez comprometen la disponibilidad del agua. De continuar con estas tasas de consumo, la seguridad hídrica se verá cada vez más comprometida y los primeros en sufrir ya sus consecuencias son los países más pobres y en particular las poblaciones que residen en las deltas fluviales.

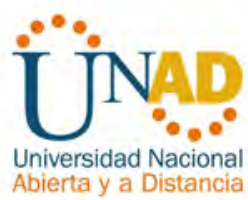

Sello Editorial 